\title{
Investigation of the Fire Performance of Building Insulation In Full-Scale and Laboratory Pire Tests
}

Wayne A. Kleinfelder

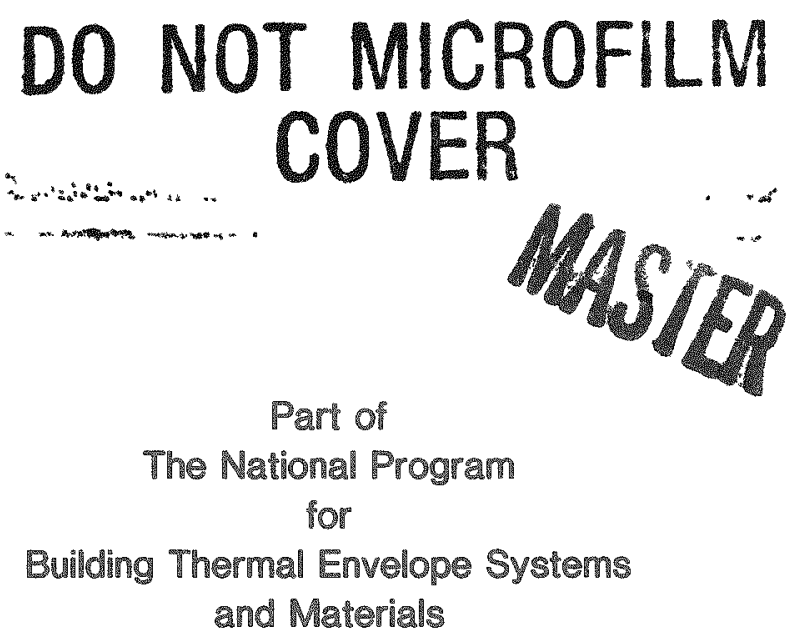

Prepared for the

U.S. Deparment of Energy Conservation and Renewable Energy Office of Buildings Energy R\&D

Building Systems Division

OPERATEI IY

UNON CABBIDE CORPORATION FOR THE UNIED STATES DEPARTMENT OF ENEREY 


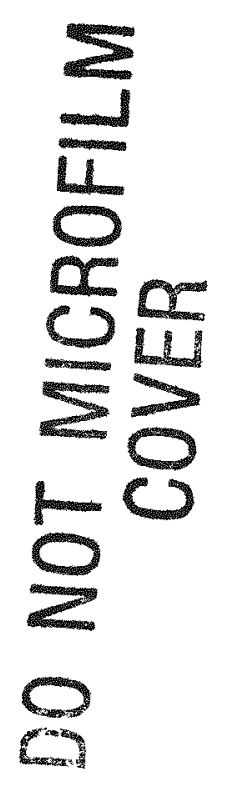
Printed in the United States of America. Available from National Technical Information Service
U.S. Department of Commerce
5285 Port Royal Road, Springfield, Virginia 22161
NTIS price codes-Prnted Copy: A07 Microfiche A01

This report was prepared as an account of work sponsored by an agency of the Unted States Government Nether the United States Government nor any agency thereof, nor any of their employees, makes any warranty, express or implied, or assumes any legal llablity or responsubulty for the accuracy, completeness, or usefulness of any information, apparatus, product, or process disclosed, or represents that its use would not infringe privately owned rights Reference heren po any specific commerclal product, process, or service by trade name, trademark, manufacturer, or otherwise, does not necessarly constitute or imply its endorsement, recommendation, or favorng by the Unted States Govermment or any agency thereof The views and opintons of authors expressed herein do not necessarily state or reflect those of the United Siates Government or any agency thereof. 


\section{DISCLAIMER}

This report was prepared as an account of work sponsored by an agency of the United States Government. Neither the United States Government nor any agency Thereof, nor any of their employees, makes any warranty, express or implied, or assumes any legal liability or responsibility for the accuracy, completeness, or usefulness of any information, apparatus, product, or process disclosed, or represents that its use would not infringe privately owned rights. Reference herein to any specific commercial product, process, or service by trade name, trademark, manufacturer, or otherwise does not necessarily constitute or imply its endorsement, recommendation, or favoring by the United States Government or any agency thereof. The views and opinions of authors expressed herein do not necessarily state or reflect those of the United States Government or any agency thereof. 


\section{DISCLAIMER}

Portions of this document may be illegible in electronic image products. Images are produced from the best available original document. 


Report Prepared by
Underwriters Laboratories, Inc.
Northbrook, Illinois
under
Subcontract Number 7863
for

Oak Ridge National Laboratory

Oak Ridge, Tennessee 37830 operated by UNION CARBIDE CORPORATION for the U.S. DEPARTMENT OF ENERGY under Contract No. W-7405 
File USNC97

\section{$\underline{N} \underline{O} I \underline{\mathrm{T}} \underline{\mathrm{E}}$}

This Report was prepared as an account of work sponsored by the United States Government. Neither the United States Government nor Underwriters Laboratories Inc., nor any of their employees nor any of their contractors, subcontractors, or their employees make any warranty, express or implied, or assumed any legal liability or responsibility for the accuracy, completeness, or usefulness of any information, apparatus, product, or processes disclosed, or represents that its use would not infringe on privately owned rights. This Report may not be used in any way to infer or to indicate acceptability for Listing, Classification, Recognition or Certificate Service by Underwriters Laboratories Inc. for any product or system. 
File USNC97

\section{TABLE OF CONTENTS}

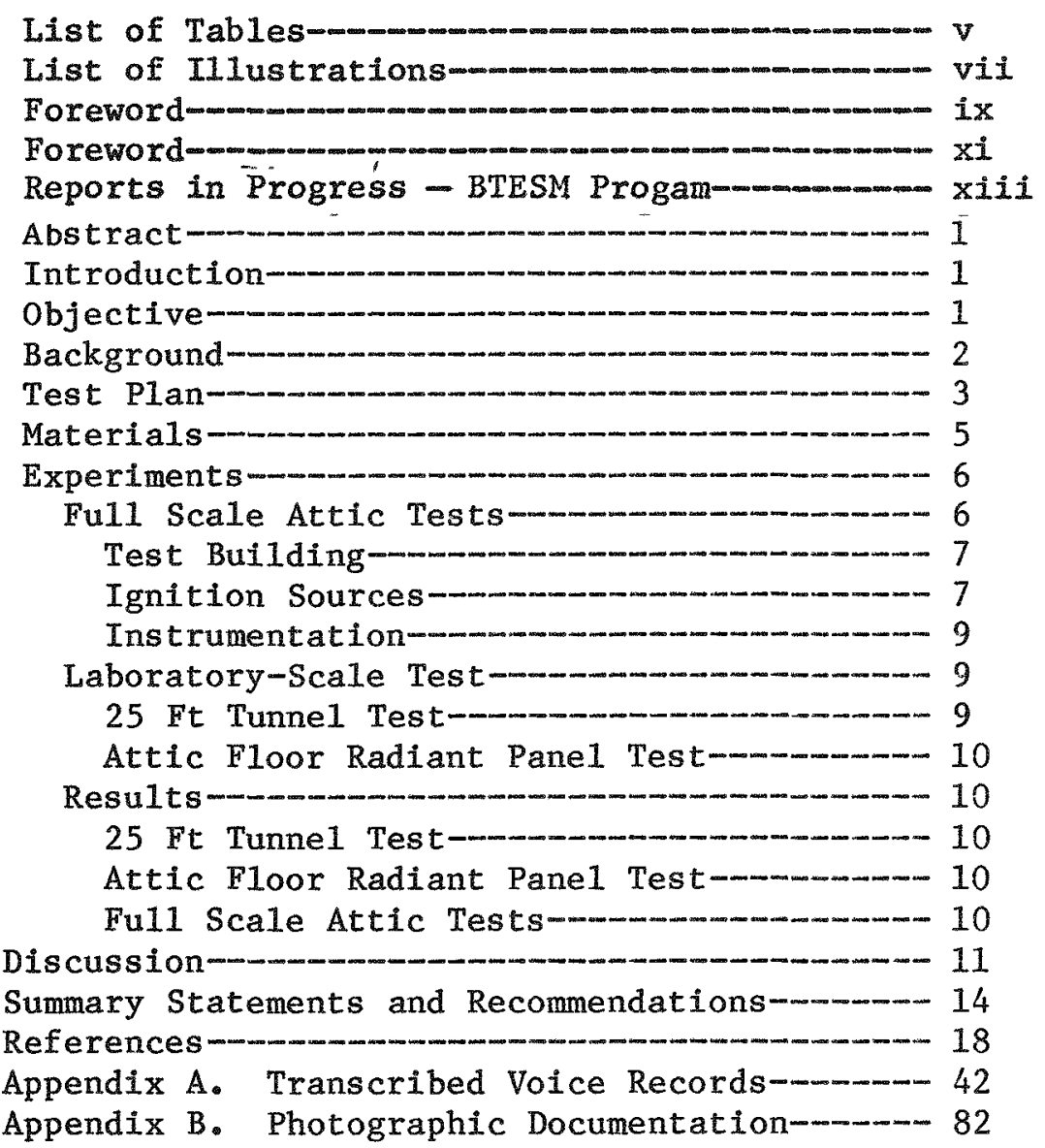




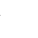




\section{Page v}

File USNC97

\section{LIST OF TABLES}

Page

Table 1. Chemica1 Formulation of Test

Materials-_-_- 19

Table 2. Atmospheric Conditions For Simulated Attic Tests-_-_- 21

Table 3. Results of Laboratory Tests-- 24

Table 4. Results of Simulated Attic Tests---- 25

Table 5. Maximum Temperatures of Recessed Light Fixtures-_- 28

Table 6. Temperature of Overloaded Electrical Wire-- 


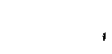




\title{
Page vii
}

File USNC97

\author{
LIST OF ILLUSTRATIONS
}

$\underline{\text { Page }}$

ILL. 1 - Fu11-Scale Simulated Attic, Front View- 30

ILL. 2 - Full-Scale Simulated Attic, Right Side View-_-_- 31

ILL. 3 - Full-Scale Simulated Attic, Left Side View-_-_-_ 32

ILL. 4 - Fu11-Scale Simulated Attic, Radiant Heater Mounting-_-_-_-_-_-_ 33

ILL. 5 - Thermocouple Locations and Ignition Source Location--_-_- 34

ILL. 6 - Graphic Representation of Flame Spread vs Percent Chemical Add-on-------- 35

ILL. 7 - Critical Radiant Flux vs Percent Chemical Loading-_-_ 36

ILL. 8 - Flame Spread vs Critical Radiant F1ux-_-_- 37

ILL. 9 - Flame Spread vs Affected Area of Flaming-- 38

ILL. 10- Percent Chemical Loading vs Rate of Smoldering Combustion--_-_-_-_-_-- 39

ILL. 11- F1ame Spread vs Rate of Smoldering Combustion-_-_-_-_-_ 40

ILL. 12- Recessed Lighting Fixture with Overlamped Bulb-_-_-_ 41 
File USNC97

FOREWORD

This is the Report of an investigation conducted by Underwriters Laboratories under Subcontract No. 7863 and Supplemental Agreement No. 1 issued by Oak Ridge National Iaboratory under a project sponsored by the U.S. Department of Energy.

The work reported was performed at UL's Northbrook, Illinois facility and was conducted during the time period of May, 1980 through November, 1981.

Respectfully submitted:

UNDERNRITERS LABORATORIES INC.

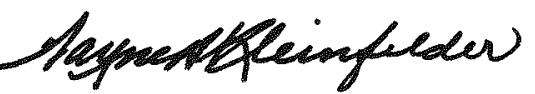

WAYNE A. KIEINFETDER

Engineering Group Leader

Fire Protection Department

Reviewed and Approved by:

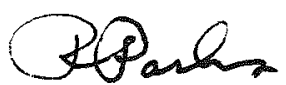

R. I. PARKS

Associate Engineer

Fire Protection Department

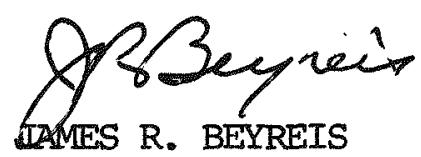

Managing Engineer

Fire Protection Department

WAK/RTP/JRB:bg 
(nt 
Page $x i$

FOREWORD

This is one of a series of reports to be published describing research, development, and demonstration activities in support of the National Program for Building Thermal Envelope Systems and Materials. The National Program involves several federal agencies and many other organizations in the public and private sectors who are addressing the national objective of decreasing energy wastes in the heating and cooling of buildings. Results described in this report are part of the National Program through delegation of management responsibilities for the DOE lead role to the Oak Ridge National Laboratory.

Ted S. Lundy

Program Manager

Building Thermal Envelope

Systems and Materials

Oak Ridge National Laboratory

Wi11iam Gerken

Program Manager, Building Systems

Division

Office of Buildings Energy R\&D

Department of Energy 

REPORTS IN PROGRESS - BTESM PROGRAM

A. IMPLEMENTATION

1. DOE/CS-0059: The National Program Plan for Building Thermal Envelope Systems and Insulating Materials (January 1979).

2. LBL-8925: Thermal Performance of Buildings and Building Envelope Systems: An Annotated Bibliography (March 1979).

3. 1980 Institute on Energy and Engineering Education, Final Status Report August 1980, ACEC Research and Management Foundation (1980).

4. STP-718: Thermal Insulation Performance: A Symposium Sponsored by ASTM Committee C-16 on Thermal and Cryogenic Insulating Materials. American Society for Testing and Materials, Tampa, Fla., 22-25 Det. 1978 (December 1980.)

5. Design + Energy: Results of a National Student Design Competition, Association of Collegiate Schools of Architecture (1981).

6. ORNL/TM-7679: Report of Ad Hoc Task Force on Indoor Air Pollution (Apri1 1981).

7. ASHRAE SP 28: Proceedings of the ASHRAE/DOE-ORNL Conference Thermal Performance of the Exterior Envelopes of Buildings December 3-5, 1979, Orlando Hyatt Hotel, Kissimmee, Florida (July 1981).

8. ACEC Research and Management Foundation, 1981 Institute on Energy and Engineering Education, (August 1981).

9. ORNL/Sub/7973/1: The National Program Plan for the Thermal Performance of Building Envelope Systems and Materials (March 1982).

10. ACEC Research and Management Foundation, Institute on Energy and Engineering Education Program Report (June 1982).

11. NAS/BRAB: Proceedings of the Conference on Energy Conservation and Firesafety in Buildings (August 1982).

12. ACSA: Design and Energy 1982: Results of the National Student Design Competition (August 1982).

13. ORNL/Sub/81-40447/1: Proceedings of the Cellulose I Conference, June 27-28, 1978, St. Louis, Missouri (August 1982).

14. Sweet's Catalog 1.lad/Deb: Energy Efficient Windows: A Key to Energy Performance (August 1982). 
15. Sweet's Catalog 1.1ad/DE: Designing for Daylighting: A Key to Energy Performance (August 1982).

16. ACSA Energy/Urban Design Charette (September 1982).

17. STP-789: Thermal Insulation, Materials, and Systems for Energy Conservation in the '80s (January 1983).

18. 1983 International Daylighting Conference, 16-18 February 1983 , Phoenix, Arizona U.S.A.: General Proceedings, Thomas Vonier, AIA, Editor (February 1983).

19. NBS/BS Series 152: A Daylighting Model for Building Energy Simulation (March 1983).

20. ORNL/CON-122: Buildings Energy Research: A Bibliography (Apri1 1983).

21. ASHRAE SP 38: Proceedings of the ASHRAE/DOE Conference Thermal Performance of the Exterior Envelopes of Buildings II (August 1983).

\section{B. MATERIALS}

1. ORNL/SUB-7556/I: Assessment of the Corrosiveness of Cellulosic Insulating Materials (June 1979).

2. ORNL/SUB-7504/3: Recessed Light Fixture Test Facility (July 1979).

3. ORNL/SUB-7559/I: Problems Associated with the Use of Urea-Formaldehyde Foam for Residential Insulation (September 1979).

4. ORNL/Sub-7551/I: Interim Progress Report on an Investigation of Energy Transport in Porous Insulator Systems (October 1979).

5. ORNL/TM-6494: A Technique for Measuring the Apparent Conductivity of Flat Insulations (October 1979).

6. ORNL/Sub-79/13660/I: Minnesota Retrofit Insulation In-Situ Test Program Extension and Review (February 1980).

7. ORNL/TM-7266: An Experimental Study of Thermal Resistance Values (R-Values) of Low-Density Mineral-Fiber Building Insulation Batts Commercially Available in 1977 (April 1980).

8. ORNL/Sub-7686/I: Smoldering Combustion Hazards of Thermal Insulation Materials (July 1980).

9. NBSIR 80-2091: Precision Measurements on Fibrous Glass Insulation (November 1980).

10. NBSIR 80-2085: Fire Performance of Loose-Fill Cellulosic Insulation in Residential Occupancies (August 1980). 
Page xv

11. ORNL/Sub-7556/2: Corrosion Testing of Urea-Formaldehyde Foam Insulating Materials (September 1980).

12. NBSIR 80-2129: Modeling for Determination of Temperatures of Electrical Cables Within Thermally Insulated Walls (October 1980).

13. DOE/CS-0192: Insulation (Fact Sheet).

14. ORNL/Sub-7715/1: Operating Temperatures for a Convectively Cooled Recessed Incandescent Light Fixture (December 1980).

15. ORNL/TM-7481: Analysis of Heat Transfer in Building Thermal Insulations (December 1980).

16. ORNL/Sub-7559/2: Problems Associated with the Use of Urea-Formaldehyde Foam for Residential Insulation. Part II: The Effects of Temperature and Humidity on Free Formaldehyde, Extractable Formaldehyde, Formaldehyde Emission and Physical Characteristics of the Foam (February 1981).

17. ORNL/Sub-7559/3: Problems Associated with the Use of Urea-Formaldehyde Foam for Residential Insulation: Part III: Residential Studies in Colorado and Wisconsin (February 1981).

18. ORNL/Sub-7559/4: Problems Associated with the Use of Urea-Formaldehyde Foam for Residential Insulation. Part IV: The Relevance of Materials Standards to Problems Associated with the Use of Urea-Formaldehyde Foam Insulation (February 1981).

19. NBSIR 81-1639: Effective Thermal Conductivity of a Glass Fiberboard Standard Reference Material (February 1981).

20. NBSIR 81-1640: Effective Thermal Conductivity of a Glass Fiberblanket Standard Reference Material (February 1981).

21. ORNL/Sub-7715/3: The Effect of Vibrations on the Density of Loose-Fill Insulations (May 1981).

22. ORNL/Sub-7715/4: Operating Temperatures of Recessed Fluorescent Fixtures with Thermal Insulation (May 1981).

23. ORNL/Sub-78/86993/1: Performance Characteristics of Foamed-In-Place Urea Formaldehyde Insulation (June 1981).

24. NBSIR 81-2350: Smoldering Combustion Hazards of Thermal Insulation Materials (August 1981).

25. NBSIR 81-1657: A Guarded-Hot-Plate Apparatus for Measuring Effective Thermal Conductivity of Insulations Between $80 \mathrm{~K}$ and $360 \mathrm{~K}$ (January 1982).

26. ORNL/TM-6433: Properties and Testing of Loose-Fill Cellulosic Insulation (February 1982). 


\section{Page xvi}

27. ORNL-CON-93: On the Occurrence of Fungi in Loose-Fill Attic Insulation in Typical Single-Family Dwellings (May 1982).

28. ORNL/Sub-7551/2: Energy Transport in Porous Insulator Systems II. Performance of Vertical Enclosures (August 1982).

29. ORNL/tr-4932: Thermal Conductivity Measurements with the Plate Apparatus: Influence of the Guard Ring Width on the Accuracy of Measurement (May 1983).

30. ORNL/TM-8891: Assessment of Reflective Insulations for Residential and Commercial Applications (October 1983).

31. ORNL/Sub-7559/5: Problems Associated with the Use of Urea-Formaldehyde Foam for Residential Insulation - Part V: Effects of UFFI Additives on Formaldehyde Emission and Physical Characteristics of the Foam (December 1983).

\section{SYSTEMS}

1. LBL-8822: A New Measurement Strategy for In-Situ Testing of Wall Thermal Performance (March 1979).

2. LBL-9821: Measurement of In-situ Dynamic Thermal Performance of Building Envelopes Using Heat Flow Meter Arrays (December 1979).

3. NBS/BS Series 123: The Effect of Moisture on the Thermal Conductance of Roofing Systems (Apri1 1980).

4. ORNL/Sub-78/97726/I: A Field Study of Moisture Damage in Walls Insulated Without a Vapor Barrier (May 1980).

5. ORNL/CON-46: An Appraisal of the M Factor and the Role of Building Thermal Mass in Energy Conservation (July 1980).

6. NBSIR 80-2100: Thermal Resistance Measurements of a Built-Up Roof System (October 1980).

7. ORNL/tr-4679: Roofing Felt on Polystyrene (December 1980).

8. ORNL/TM-7629: Roofing Research - A Bibliography (Apri1 1981).

9. ORNL/TM-7640: The Assessment of Roofing Research. An Interim Report (Ju1y 1981).

10. Southwest Thermal Mass Study, Tesuque Pueblo, New Mexico: Construction and Instrumentation Phase (October 1, 1981).

11. LBL-13436: The Envelope Thermal Test Unit (ETTU): Field Measurement of Wall Performance (October 1981).

12. LBL-13510: The Determination of the Dynamic Performance of Walls (November 1981). 
Page xvii

13. LBL-13503: Simplified Thermal Parameters: A Model of the Dynamic Performance of Walls (December 1981).

14. NBSIR 81-2443: Plan for A Round Robin of Hot Boxes (February 1982).

15. CERL TR/M-308: Insulation Retrofit Under Low-Slope Roofs (February 1982).

16. CONF-811179: Proceedings DOE-ORNL Workshop on Mathematical Modeling of Roofs, November 3-4, 1981, Atlanta, Georgia (Apri1 1982).

17. ORNL/Sub-95006/1: Thermal Roof Systems Performance Study (March 1983).

18. ORNL/TM-8571: Thermal Envelope Field Measurements in an Energy-Efficient Office and Dormitory (Apri1 1983).

19. ORNL/Sub-42539/1: Heat Transfer Characteristics of a Structural Normal Weight Conerete Wall (February 1983).

20. ORNL/Sub-42539/2: Heat Transfer Characteristics of a Structural Lightweight Concrete Wall (June 1983).

21. CONF-8206130: Proceedings of the Building Thermal Mass Seminar 1982 (August 1983).

22. ORNL/Sub-81-22293/1: Energy Savings Potential of Roofing Research (August 1983).

23. ORNL/Sub-42539/3: Heat Transfer Characteristics of a Low Density Concrete Wall (August 1983).

24. ORNL/CON-97: Thermal Mass Assessment (September 1983).

D. DIAGNOSTICS

1. NYSERDA 79-10: Aerial Measurement of Heat Loss - Phase I (July 1979).

2. DOE/CS/20413-01: Status of Thermal Imagery Technology as Applied to Conservation - Update 1 (July 1980).

3. ORNL/Sub-80/61602/1: Assessment of Building Diagnostics (Ju1y 1981).

4. NASA TM-81766: Reliable Aerial Thermography for Energy Conservation (August 1981).

5. Proceedings of the Society of Photo-optical Instmumentation Engineers: Thermal Infrared Sensing Applied to Energy Conservation in Building Envelopes (Thermosense III), September 2-5, 1980, Vol 254 (February 1981). 
6. Proceedings of SPIE - The International Society for optical Engineering: Thermal Infrared Sensing Applied to Energy Conservation in Building Envelopes (Thermosense IV), September 1-4, 1981, Vo1. 313 (June 1982).

7. ORNL/Sub-9001/1: Aerial Measurement of Heat Loss: Phase II, (Ju1y 1982).

8. ORNL/Sub-9001/1: Community Demonstration of Aerial Thermography Techniques (August 1982).

8. NBSIR 82-2510: Quality of Inspections Utilizing Infrared Technology on Weatherization Retrofit Installations, (November 1982).

9. Proceedings of SPIE - The International Society for Optical Engineering: Thermal Infrared Sensing Diagnostics (Thermosense V), october 25-27, 1982, Vo1. 371 (May 1983).

E. INNOVATIVE CONCEPTS

1. ORNL/CON-61: An Experimental Plan for Investigating Building-Earth Heat Transfer at the Joint Institute for Heavy-Ion Research Building (December 1980).

2. ORNL/TM-8018: Large Climate-Moderating Envelopes for Enclosed Structures: A Preliminary Evaluation of Energy Conservation Potential (December 1981 ).

3. ORNL/Sub-81/40451/1: Regional Analysis of Ground and Above-Ground Climate (December 1981).

4. ORNL/Sub-80-70513/1: Financing Earth-Sheltered Housing - A Report on a Program to Facilitate the Loan Process (February 1982).

5. ORNL/CON-86: Earth-Sheltered Housing, An Evaluation of Energy-Conservation Potential (April 1982).

6. ORNL/CON-87: Use of Vegetation to Ameliorate Building Microclimates: An Assessment of Energy Conservation Potentials (Apri1 1982).

7. Earth Sheltered Structures Fact Sheets:

ORNL/Sub-7849/01: Site Investigation (December 1981). ORNL/Sub-7849/02: Planting Considerations (November 1981). ORNL/Sub-7849/03: Waterproofing Techniques (December 1980). ORNL/Sub-7849/04: Waterproofing Considerations and Materials (September 1981).

ORNL/Sub-7849/05: Insulation Principles (May 1981). ORNL/Sub-7849/06: Insulation Materials and Placement (May 1981). ORNL/Sub-89741V-01/07: Daylighting Design (August 1981). 


\section{Page xix}

ORNL/Sub-89741V-02/08: Indoor Air Quality (August 1981).

ORNL/Sub-89741V-03/19: Earth Coupled Cooling Techniques (August 1981).

ORNL/Sub-89741V-04/10: Disaster Protection (September 1981).

ORNL/Sub-89741V-05/11: Building in Expansive Clays (September 1981).

ORNL/Sub-89741V-06/12: Passive Solar Heating (September 1981).

8. ORNL/CON-91: Cost and Energy Comparison Study of Above and Below Grade Dwellings (August 1983). 
INVESTIGATION OF THE FIRE PERFORMANCE OF BUILDING INSULATION IN FULL-SCALE AND LABORATORY FIRE TESTS

\author{
Wayne A. Kleinfelder
}

\begin{abstract}
Twenty-two insulations are exposed to fire tests including the 25 ft Tunnel test, the Attic Floor Radiant Panel test and actual fire conditions of a simulated attic configuration. The insulations consisted of a number of cellulose fiber insulations, utilizing various chemical treatments, glass fiber and mineral fiber insulations. The fire performance characteristics of the insulations were measured in each of the three test scenarios and the report compares their results.
\end{abstract}

\title{
INTRODUCTION
}

This is a report of a fire test investigation on primarily cellulose insulation materials when exposed to two standard laboratory test methods and to actual conditions as represented by a simulated wood joisted attic. The investigation included tests on 19 samples of treated cellulose fiber, untreated cellulose fiber, a glass fiber and a mineral wool insulation.

One of the laboratory test methods was the $25 \mathrm{ft}$ Tunnel test as described in "Test Method for Surface Burning Characteristics of Building Materials" (variously designated as UL 723, ASTM E-84, NFPA 255 and ANSI A.25).1 The second laboratory test method is known as the "Attic Floor Radiant Panel Test" (AFRP) which is described in detail in "Standard Method of Tests for Critical Radiant Flux of Exposed Attic Floor Insulation Using a Radiant Heat Energy Source." 2 The third fire exposure was performed in a simulated wood frame attic representative of construction practices and materials commonly in use today. The performance of the materials in the simulated attic was used as a bench mark for judging the performance of the two laboratory tests.

A total of 66 simulated attic tests were performed in this investigation along with 37 tunnel tests and 57 AFRP tests. For the attic tests, two flaming ignition sources were used; alcohol spill and a propane torch and four non-flaming ignition sources were used; cigarettes, overheated electric wire, and a recessed light fixture (rated lamp and overrated lamp).

\section{OBJECTIVE}

The objective of the investigation was to: (1) determine the actual performance of the insulations in the attic environment, and (2) to compare the abilities of the laboratory tests to properly assess the performance of the insulations by comparing their results to the attic results. 
Page 2

File USNC97

\section{BACKGROUND}

Cellulose loose fill insulation is required by law to conform to requirements set forth in the Consumer Product Safety Commission's (CPSC) Interim Safety Standard For Cellulose Insulations. The current version of the CPSC Standard 3 provides for the use of the Attic Floor Radiant Panel Test.2,3 But prior to the adoption of the current version, fire performance characteristics were determined using the 25-Ft Tunnel Test 4 method and approximately 1200 tests of cellulose insulation materials using the 25-Ft Tunnel Test were conducted by Underwriters Laboratories under a contract arrangement with CPSC.

Data provided in consideration of the proposed adoption of the AFRP Test, as a replacement for the $25 \mathrm{Ft}$ Tunnel Test, was limited to 1 ) interlaboratory studies to investigate repeatability and reproducibility 2,5 of the AFRP Test and 2) a preliminary study of fire behavior in a full-scale attic 6 . While the behavior of insulation in the attic fires was compared with performance in the AFRP Test, no comparison was made to the $25 \mathrm{Ft}$ Tunnel Test results. Therefore, no information was presented to indicate a need to abandon the Tunnel Test Method.

In order to supplement the data in the above studies and to provide results of the 25-Ft Tunnel Test for comparison purposes, UL conducted an in-house investigation of building insulations using full-scale and both type of laboratory fire test methods. The initial work of the program concentrated on the fire performance of cellulose insulations in a full-scale test geometry which incorporated several ambient test conditions. The results of this program were presented in a report entitled "Flammability of Therma1 Insulation Materials in Laboratory Tests and a Simulated Attic."7

The work described in the following is a continuation of that described in UL's in-house investigation, and its intent is to assess the suitability of the AFRP Test and the 25-Ft Tunnel Test for evaluating the fire behavior of cellulose and other insulations in a full size attic. 
File USNC97

\section{TEST PLAN}

The plan of this investigation was to compare the relationship between the results of full-scale simulated attic fire tests and the 25-Ft Tunnel Test and AFRP Test for a variety of cellulosic insulations. For comparison purposes, untreated cellulose, shredded glass fiber and blown mineral wool insulations were also examined in the investigation.

Initially, cellulose insulation materials manufactured using the same chemical formulation but varying the chemical add-on rate were evaluated by the 25-Ft Tunnel Test. The chemical add-on rate is defined as the percent by weight of chemical contained in the finished material. The chemical add-on rates of these cellulosic materials were designed to produce flame spread values of approximately 25,35, 45, 55 and 65 as measured by the 25-Ft Tunnel Test.

These same five materials were used in a series of attic tests to bracket the flame spread value corresponding to the threshold of full fire involvement under the influence of a flaming ignition source.

After determining the flame spread values that bracketed the threshold of full fire involvement, four additional typical formulations of cellulose insulation were subjected to laboratory and simulated attic tests. These four additional formulations used different treatment chemicals than that of the first samples and were designed with chemical add-on rates to produce values of flame spread near the threshold values, both above and below. It was the purpose of these additional formulations to determine if similar flaming and smoldering conditions existed for a variety of typical chemical formulations presently being used in the industry.

Six additional samples of cellulosic insulation were added to the investigation. These samples were provided by the Department of Energy and are presently being used in other investigations to study the flammability permanency of these materials. The test data developed in this Report will be used to supplement the data from the permanency investigation. 
File USNC97

Two flaming ignition sources, and four non-flaming ignition sources were also utilized to produce a smoldering condition within the insulation in the full-scale attic fire tests. These non-flaming sources consisted of: 1) a recessed lighting fixture, with both rated and over-rated lamps, 2) cigarettes, and 3) overheated electrical wiring. In those experiments involving the recessed lighting fixture, the insulation materials surrounded the fixture in order to confine heat and induce smoldering of the insulation. This type of installation condition would be in violation of the National Electrical Code8, but in this case, the objective was to study the effects on the insulation, not the performance of the recessed fixture.

In a11 attic tests, the attic was preheated by either convective heating to simulate summer conditions.

It was the purpose of those attic tests that utilized the cigarette ignition source to evaluate the potential of the insulation samples to support smoldering combustion when exposed to a localized high temperature ignition source.

The experiments with overheated electric wire were conducted with a No. 14 gauge copper wire loop installed in the center of a joist cavity at mid-depth in the insulation. The copper wire was stripped of its insulation jacket at the end of the loop to provide intimate contact with the bared wire and test material. A current of 48 amperes ac was supplied from a 115 volt source through a current limiting resistor.

While the number of materials, heating modes and ignition sources created one hundred seventy-six potential combinations for the full-scale simulated attic tests, the actual number of tests conducted was reduced by selective test procedures that eliminated redundant tests. For example, if smoldering combustion was present in a cellulosic sample, the corresponding sample having the same formulation but a lesser chemical add-on rate was not conducted. This approach permitted a reduction in the number of tests conducted to sixty-six. 
File USNC97

\section{MATERIALS}

Cellulosic loose fill materials, shredded glass fiber, and blown mineral wool products were evaluated in this project.

The cellulose samples were specifically formulated for this project by a cellulose manufacturer utilizing normal manufacturing procedures.

The various chemical formulations for the cellulose samples and installed blown density values of all samples are shown in Table 1 .

Those cellulose samples used to bracket the value of flame spread corresponding to the threshold of full fire involvement in the fu11-scale simulated attic tests are identified as samples A through $E$. The four additional formulations of cellulose that were manufactured to produce flame spread values below the threshold of fire involvement are identified as samples $\mathrm{G}$ through $\mathrm{J}$; and those above the threshold are identified as samples $\mathrm{K}$ through $\mathrm{N}$. Those above the threshold had the same chemical formulation as those below but contained a lesser chemical add-on. The untreated cellulose, shredded glass fiber, and blown mineral wool were identified as samples $F, O$, and $P$, respectively.

In addition, the six additional samples of cellulose mentioned previously that were received from the Department of Energy were evaluated. These are identified in this Report as samples $Q$, $\mathrm{R}, \mathrm{S}, \mathrm{T}, \mathrm{V}$, and $\mathrm{W}$.

A11 sample materials were blown through a machine designed for field application of the material. The machine consisted of a $40 \mathrm{lb}$ capacity hopper, a $1 \mathrm{hp}$ blower, a 1/3 hp agitator motor and 2 in. diameter plastic blowing hose. The test materials were installed in a manner commensurate with typical field practice such that the material was blown in a direction parallel to the attic joist to assure complete filling of the joist cavity and elimination of possible air spaces or voids in the insulation. 
Page 6

File USNC97

\section{EXPERIMENTS}

\section{Full Scale Attic Tests}

The purpose of this portion of the investigation was to evaluate the fire performance of various materials in a simulated full-scale attic exposed to ignition sources representative of field conditions. The simulated attic was fabricated using typical construction practices. In order to simulate summer conditions, provision was made to conduct tests at an elevated ambient temperature.

The attic assembly was constructed of materials and methods commonly used in field construction. The assembly consists of a chamber $8 \mathrm{ft}$ wide and $12 \mathrm{ft}$ long with a sloping roof inclined from the level of the joists at one end to a height of approximately $5 \mathrm{ft}$ at the other end, as shown in ILIS. 1, 2 and 3. Roof rafters and vertical studs were nominal 2 by 4 in. lumber, and the attic floor joists were nominal 2 by 6 in. lumber on 16 in. centers. The roof rafters and vertical sides of chamber were sheathed with $1 / 2$ in. plywood. The underside of the joists was covered with $1 / 2$ in. gypsum wallboard.

The attic space was preheated for several hours to an ambient attic temperature of $150 \mathrm{~F}$ before each test. For comparative purposes, two heating methods were used, one convective and one radiative. Although the heating of an attic space in reality is achieved by the radiant effect of the sun, the majority of the attic tests were conducted using a convective heating method. This method achieved the $150^{\circ} \mathrm{F}$ ambient temperature much quicker than the radiant method, and exposed the materials to the elevated temperature for a longer duration within the confines of test period.

The convective method employed a portable kerosene heater to blow hot air into the structure through a flexible supply duct. A diffusing baffle was installed at a distance of 12 in. from the outlet end of the supply duct and in a plane perpendicular to the duct. The baffle was used to uniformly distribute the hot air throughout the attic space (IIISS.1, 2 and 3). The distance between the exhaust end of the heater and the inlet end of the supply duct was adjusted to produce the desired attic temperature. This heater was allowed to operate for approximately $5 \mathrm{hr}$ prior to conducting the test in order to develop an equilibrium condition. Immediately before the test, heating was discontinued. 
File USNC97

The radiative heating method used two $4 \mathrm{ft}$ long radiant heaters with a total capacity of $1500 \mathrm{w}$, fastened directly to the rafters. A blackened baffle was positioned parallel to and approximately 8 in. below the heaters. These heaters were operated for approximately $5 \mathrm{hr}$ prior to and during the test. This assisted in maintaining the desired air temperature during the early stages of the test.

The various insulation materials were installed in a blown density condition between the ceiling joists to provide a simulation of exposed insulation in an open attic of a wood frame residential dwelling.

Sample materials in all tests filled the joist cavities to the top of the joists. In most attic tests, all joist cavities were filled, but a few tests were performed for comparison purposes with only two adjacent joist cavities filled.

Test Builaing

All ful1-scale simulated attic tests were conducted in a fire test building approximately 60 by 60 by $16 \mathrm{ft}$ high and equipped with afterburners for smoke abatement purposes. Atmospheric conditions were not controlled in this fire test room but were recorded as part of the test record and are shown in Table 2.

Ignition Sources

The application of the various ignition sources was located near the center of the instrumented joist cavity approximately 12 in. from the $4 \mathrm{ft}$ high end wall.

The flaming ignition source in most of the simulated attic tests used $15 \mathrm{~m} 1$ of absolute ethyl alcohol ignited with a match. The alcohol was applied to the test material over a circular area approximately $50 \mathrm{~mm}$ in diameter. The alcohol was selected because of the ease of handling and application, reproducible burning rate, and the ability to develop a surface burning fire without prolonged contribution from the ignition source. 


\section{Page 8}

File USNC97

Two attic tests were conducted in which the ignition source was a propane burner flame applied continuously to the surface of the insulation at the same previously noted location.

The recessed electric ceiling fixture was purchased on the open marketplace. It was rated for a 60 watt incandescent lamp, and measured 6-3/4 in. square and 4-1/2 in. deep. The housing was made of steel and incorporated a white 8 in. square opaque glass. To produce the over-rated lamp condition, a $150 \mathrm{~W}$ incandescent bulb was inserted into the fixture without any modification. In all attic tests that utilized the recessed fixture, all insulation materials were blown to completely surround and cover the fixture. As in previous tests, the attic enclosure was preheated for approximately five hours. The fixtures were electrically activated at the start of the preheating phase and continued for a minimum four hours after the heating was discontinued. Measurements were made of the extent of insulation material discoloration and smoldering rate if present.

The cigarette ignition source consisted of cigarettes without filter tips, made from natural tobacco and were approximately $85 \mathrm{~mm}$ long with a tobacco packing density of approximately $0.27 \mathrm{~g} / \mathrm{cm}^{3}$ and a total weight of approximately $1.1 \mathrm{gm}$. The cigarette was inserted vertically, with the lit end up, into the test sample at the center of the joist cavity. The burning of the cigarette and the smoldering of the sample material were allowed to proceed undisturbed in the attic for a minimum of $4 \mathrm{hr}$. The rate of smoldering in in./hr was recorded for each material.

Attic test with overheated electric wires was conducted with a No. 14 gauge bared copper wire loop installed in the center of a cavity at mid-depth in the insulation as shown on ILL. 5. The current load of 48 amperes was selected to represent the upper range that would be anticipated in residential dwellings. The temperature rise of the bare wire buried in the insulation was monitored during the test and measurements made of discoloration and/or any smoldering that developed. 
File USNC97

\section{Instrumentation}

In the attic tests, temperatures were monitored by a grid of Type $\mathrm{K}$ Inconel-sheathed thermocouples located in the air, at the insulation upper surface and internally within the test material as indicated in ILL. 5. Thermocouples were also positioned on the steel housing of the recessed lighting fixtures and on the overheated electrical wire.

\section{Laboratory Scale Tests}

\section{Ft Tunne1 Test}

The 25-Ft Tunnel Tests were conducted in accordance with UL 723 (ASTM E84) - "Tests For Surface Burning Characteristics of Building Materials." 1 The apparatus consists of a chamber measuring approximately $18 \mathrm{in}$. wide, $13 \mathrm{in}$. deep, and $25 \mathrm{ft}$ long. The test samples are placed in the ceiling position spanning the width and length of the chamber. The test samples are exposed to a controlled ignition flame from the floor of the chamber with an induced air velocity across the surface of the sample such that an area of approximately $7 \mathrm{sq} \mathrm{ft}$ is under direct impingement of the ignition flame. Observations are made on the propagation of the flame along the length of the sample.

It is the purpose of this test to determine the comparative burning characteristics of the sample under test by evaluating the spread of flame over its surface. The values for flame spread are compared with a combustible material (red oak lumber) as approximately 100 , and a noncombustible material (asbestoscement board) as 0 on the classification scale. During the tests, a11 materials were supported in the ceiling position by an angle-iron frame with a 100 mesh steel screen stretched over the bottom of the support frame. As indicated in the Guide to Mounting Methods described in Appendix A of UL 723.1 Since the wire screening retards flame propagation, the observed results were adjusted using a correction factor that has been previously determined experimentally. The correction factor used was 1.30. This technique is presently described in the Appendix of the above Standards. 
File USNC97

\section{Attic Floor Radiant Panel Test}

All test materials were subjected to the Attic Floor Radiant Pane1 Test. Tests were conducted in accordance with the method entitled "Standard Method of Test for Critical Radiant Flux of Exposed Attic Floor Insulating Using a Radiant Heat Energy Source," as current1y specified in the GSA HH-I-515D Specification for "Insulation Thermal (Loose Fill for Pneumatic or Poured Application): Cellulosic or Wood Fiber,"2 and the Consumer Product Safety Commission Interim Safety Standard (16 CFR Part 1209 dated July 6,1979$) .3$

The apparatus operated with a gas fired radiant panel inclined at a $30^{\circ}$ angle above a horizontal sample. The radiant panel generates a radiant energy flux distribution ranging along the approximate $100 \mathrm{~cm}$ length of the test sample from $1.2 \mathrm{~W} / \mathrm{cm}^{2}$ at the end near the radiant panel to $0.10 \mathrm{~W} / \mathrm{cm}^{2}$ at the other end.

Results

\section{$25 \mathrm{Ft}$ Tunnel Test}

The flame spread results by the $25 \mathrm{Ft}$ Tunnel Test are summarized in Table 3 and graphically represented in ILL. 6.

\section{Attic Floor Radiant Panel Test}

Values of Critical Radiant Flux (CRF) measured with the AFRP Test apparatus are summarized in Table 3 and graphically displayed in ILL. 7.

\section{Full Scale Attic Tests}

The results of the sixty-six simulated attic tests are summarized in Table 4. Voice records made during the conduct of each of the attic tests have been transcribed and edited for clarification, and appear in Appendix A. Typical photographs taken during the tests are included as Appendix B. 
Page 11

File USNC97

\section{DISCUSSION}

For the treated cellulose materials investigated, as the loading or add-on rate of the chemical was reduced, the resulting flame spread values increased, as shown in Table 3 . This is demonstrated by samples A through $E$, which incorporated the same chemical formulation but different chemical loadings. The relationship of chemical add-on and the resulting flame spread values are graphically shown in ILL. 6. This graph displays a linear relationship of flame spread versus percent chemical add-on. It may be noted that the resulting flame spread values were substantially influenced by the percentage of chemicals utilized. However, the flame spread values exhibited by the materials were less affected by the type of chemicals incorporated. It may also be noted that a percent chemical add-on of 16 or greater resulted in flame spread values at or below the threshold values.

The AFRP Test produces radiant heat flux on the sample which varies from $1,2 \mathrm{~W} / \mathrm{cm}^{2}$ at the end nearest the radiant source to $0.10 \mathrm{~W} / \mathrm{cm}^{2}$ at the other end of the sample. The majority of the cellulose materials used experienced burning the length of the sample, and thus the reported CRF would be $0.10 \mathrm{~W} / \mathrm{cm}^{2}$. This is shown by the relationship between CRF and percent chemical add-on in ILL. 7. It is noted that 8 percent of the measurement range of the apparatus was utilized, and 11 of 18 cellulosic samples tested developed the lowest possible value of CRF, $0.10 \mathrm{~W} / \mathrm{cm}^{2}$. Thus, for this application, the AFRP Test is used near the limit of its measurement range, and it is incapable of making any distinction among those materials whose CRF are only slightly less than the acceptance limit of $0.12 \mathrm{~W} / \mathrm{cm}^{2}$. This condition exists because the sample was not long enough in relation to the level of radiant energy imposed, or the level of radiant energy was too great for the size of sample being tested.

Comparison of the flame spread values and the values of CRF (Table 3) suggests that materials having flame spread values of 25 or less usually show a CRF of $0.12 \mathrm{~W} / \mathrm{cm}^{2}$ or greater. Materials having flame spread values of approximately 30 or greater exhibited values of CRF of $0.10 \mathrm{~W} / \mathrm{cm}^{2}$. Since the AFRP Test method is unable to indicate values of CRF less than $0.10 \mathrm{~W} / \mathrm{cm}^{2}$, it was not possible to establish the relationship between $C R F$ values and flame spread values for materials having flame spread values generally greater than 25. This is graphically displayed on ILL. 8. It is not known why sample $T$, as shown on ILL. 8, developed poor CRF values as compared to other samples having flame spread values of 25 or less. However, it should be noted that sample $T$ contained the least amount of borate chemicals and the highest amount of sulphate chemicals than any other sample evaluted. 
Page 12

File USNC

Although all cellulosic loose fill materials supported flaming combustion in the attic tests, those materials that exhibited a flame spread of 40 or greater, propagated flaming combustion to a much greater extent than did the materials with flame spread values of 35 or less. Six of the ten attic tests conducted on the 40 or greater flame spread materials resulted in full flaming involvement. The remaining four tests developed results, in terms of affected area, in the range of 31 to $44 \mathrm{sq} \mathrm{ft}$. The eight attic tests conducted on the 35 or less flame spread materials resulted in affected areas of $4.7 \mathrm{ft}^{2}$ or less.

A graphic representation of flame spread and the affected area of flaming by the alcohol spill in the attic tests, is shown on ILL. 9. From this graph, it is shown that samples having a flame spread value of 35 or less restricted the affected area to less than $5 \mathrm{ft}^{2}$. This identified the threshold for full flame involvement as occurring between the flame spread values of 35 to 40 .

The corresponding threshold value of CRF appears to be less than $0.10 \mathrm{~W} / \mathrm{cm}^{2}$, which is beyond the measurement range of the AFRP Test. Seventeen tests were conducted utilizing materials with a flaming ignition source that exhibited a CRF of $0.10 \mathrm{~W} / \mathrm{cm}^{2}$. Six of these materials resulted in full attic involvement (96 $\mathrm{ft}^{2}$ ). Four developed involvement in terms of affected area of 31 to $44 \mathrm{ft}^{2}$. Seven resulted in affected areas of $4.7 \mathrm{ft}^{2}$ or less.

The 25-Ft Tunnel Test provides a means of ranking or grading the flammability performance of cellulosic materials in comparison of the results developed in the attic tests. However, because the measurements are limited to values of CRF greater than $0.10 \mathrm{~W} / \mathrm{cm}^{2}$ by the AFRP Test apparatus, correlation cannot be made with the attic tests in terms of flammability performance for materials that developed test results near the threshold values.

Ten of the fifteen cellulosic insulations tested that utilized the cigarette ignition source developed smoldering combustion. The rate of smoldering ranged from 3.25 in. per $h$ for loose fill material having a flame spread of 25 to 6.6 in. per $h$ for untreated cellulose having a flame spread of 70 . Those samples that did not support smoldering combustion were $Q, S, T, V$, and $W$. These samples all had chemical add-on rated of 25 percent by weight. Sample $R$ also had a chemical add-on rate of 25 percent but supported smoldering combustion at a rate of 3.4 in. per h (Tests 49 and 54). This is consistent with the National Bureau of Standards observation that the effect of borax is to increase the amount of boric acid needed to inhibit smoldering in the cigarette ignition test. Of the 
File USNC97

samples that contained 25 percent chemical add-on (Table 1), sample $R$ had the highest percent of borax and therefore a higher smoldering rate would be expected. This is graphically displayed in ILL. 10 .

The relation of the rate of smoldering combustion by cigarette ignition to flame spread is shown in ILL. 11. A similar relationship of smoldering combustion to percent chemical add-on is shown in ILL. 10. As shown on graphs 10 and 11 , the smoldering rate of samples $H$ and $I$ are significantly higher as compared to other materials having similar chemical add-on rates. It is noted that materials $H$ and $I$ contain sulphate chemicals which do not restrict the rate of smoldering combustion as well as borax and boric acid chemicals at similar chemical add-on rates.

The blown mineral wool and shredded glass fiber materials (samples $P$ and $O$, respectively) did not support flaming when exposed to the flaming ignition sources nor smoldering combustion when exposed to the nonflaming ignition source in the attic test.

In those tests that utilized the recessed light fixture in a rated lamped condition (i.e., $60 \mathrm{w}$ bulb), smoldering combustion was not developed. The maximum temperatures that were observed during each test, as measured by a thermocouple positioned on the housing of the fixture, are shown in Table 5. With the same smaples exposed to the light fixture in an over-rated condition (i.e., with a $150 \mathrm{w}$ bulb), all materials developed smoldering combustion. These are shown in Table 4 and the maximum temperatures observed are shown in Table 5.

When the fixture housing reached a temperature in the range of 475 to $550^{\circ} \mathrm{F}$, temperatures within the insulation began to rise at a faster rate. This sudden change in the rate of temperature rise indicated that the material had begun to support smoldering combustion. As shown in Table 5, the maximum temperature of the fixture with the $60 \mathrm{~W}$ bulb was $320^{\circ} \mathrm{F}$, with no evidence of smoldering combustion in any of the materials tested. The lowest temperature of the fixture utilizing the $150 \mathrm{~W}$ bulb was $480^{\circ} \mathrm{F}$ and all materials supported smoldering combustion. 
File USNC97

I11ustration 12 shows time-temperature histories of the recessed light fixture housing in an overlamped condition for several representative attic tests. The shaded area of the graph represents the range of temperatures in which cellulose materials reportedly begin to support smoldering combustion $\left(475-550^{\circ} \mathrm{F}\right)$. The " $\mathrm{x}$ " located in each of the temperature profiles represents the time at which a sudden increase in the rate of temperature rise occurred, and is believed to be the point at which the materials began to support smoldering combustion. The following are the times and temperatures at which smoldering is believed to have begun for the four materials involved.

Test No. Material Temperature, ${ }^{\circ} \mathrm{F}$ Time, Min Percent Add-On

$\begin{array}{lllrl}62 & \text { W } & 545 & 70 & 25 \\ 27 & \text { B } & 535 & 105 & 19 \\ 34 & \text { G } & 530 & 75 & 16 \\ 35 & \text { I } & 480 & 55 & 16\end{array}$

It is noted that sample I, which contained sulphate chemicals, smoldering combustion occurred sooner and at lower temperature than did Sample $G$, which contained borate chemicals; and both had 16 percent chemical loading.

The overloaded electrical wire resulted in a maximum temperature, as measured on the wire of $315^{\circ} \mathrm{F}$ after $8 \mathrm{~h}$ of exposure with a current of 48 amperes (Table 6). No discoloration or evidence of smoldering was present. No further tests were conducted using the overheated wire since it was known from the light fixture experiments and other studies 9,10 that the threshold for smoldering combustion is approximately $500^{\circ} \mathrm{F}$.

\section{SUMMARY STATEMENTS AND RECOMMENDATIONS}

Sixty-six simulated attic tests were conducted on twenty different cellulose loose fill materials, one shredded glass fiber product, and one mineral wool insulation in this investigation. Information developed is summarized as follows: 
File USNC97

1. The data generated indicated that the 25-Ft Tunnel Test is capable of distinguishing between materials which did or did not propagate flames in the simulated attic tests. Those materials that limited flaming to the immediate area of the ignition source had flame spread values of 35 or less. Those materials that did not confine the flaming to the immediate area of the ignition source had flame spread values of 45 or greater.

2. The present acceptance criterion ${ }^{3}$ of $0.12 \mathrm{~W} / \mathrm{cm}^{2}$ is near the lowest critical radiant flux (CRF) that the Attic Floor Radiant Panel (AFRP) Test is capable of measuring for the cellulose insulations used. All materials with lower CRF received the same value, e.g., $0.10 \mathrm{~W} / \mathrm{cm}^{2}$, the minimum value measurable. Because the AFRP Test is incapable of providing values of the CRF less than $0.10 \mathrm{~W} / \mathrm{cm}^{2}$ for the cellulose materials, threshold values of the CRF for full attic involvement fall outside the measurement range of the test. Thus, the AFRP Test did not always distinguish between materials which did or did not propagate flames in the simulated attic tests with a flaming ignition mode. The acceptance criterion of $0.12 \mathrm{~W} / \mathrm{cm}^{2}$ thus eliminates some materials shown to perform acceptably in the simulated attic.

3. Blown mineral wool and shredded glass fiber materials did not support flaming or smoldering combustion in the simulated attic tests.

4. The attic tests that utilized the cigarette ignition source developed a rate of smoldering combustion for all cellulose products having a chemical add-on rate of less than 25 percent by weight. The rate of smoldering ranged from $3.25 \mathrm{in}$. per $\mathrm{h}$ for cellulose material having a flame spread of 25 to 6.60 in. per $\mathrm{h}$ for untreated cellulose. Accordingly, the 25 ft Tunnel test method provides an indication of relative smoldering combustion propagation rate for materials having various treatment levels.

5. The results indicated that sulphate chemicals do not restrict the rate of smoldering combustion in cellulosic loose fill formulations as well as borate chemicals at similar chemical add-on rates. 
File USNC97

6. For the materials used, the flaming characteristics of cellulose materials, as measured by the 25-Ft Tunnel Test, were less influenced by the type of chemicals utilized than by the percentage of chemical add-on (ILL. 6). However, smoldering combustion was influenced significantly by both the type of chemical and the amount of add-on (ILLS. 10 and 11).

7. Smoldering combustion was not produced when the various cellulose materials were exposed to the recessed 1ight fixture using its rated lamp capacity $(60 \mathrm{~W})$, regardless of the chemical loading, flame spread or CRF values. Smoldering combustion was produced in all cellulose materials when the recessed light fixture was overlamped $(150 \mathrm{~W})$.

8. It was demonstrated that the cellulose insulation materials used will begin to support smoldering combustion when exposed to a heat source that will develop temperatures in the range of 475 $550^{\circ} \mathrm{F}$.

9. Test results indicated that smoldering combustion did not occur in the cellulose material when exposed to an overloaded 14 gauge electric wire with a current 48 amperes. Temperatures on the wire did not exceed $320^{\circ} \mathrm{F}$ for an $8 \mathrm{hr}$ period. These results are based on a limited time exposure. The effect of lesser temperatures over longer periods of time was not investigated.

The results of this investigation suggest continued research, development and testing in several areas as follows:

1. Additional tests should be conducted to develop data that would allow for the analysis of the relationship that may exist between treating chemical add-on percentages and the smoldering combustion of the finished cellulosic insulation at an ambient temperature of $150^{\circ} \mathrm{F}$.

2. Additiona1 tests should be conducted to develop data on the maximum ambient temperature needed to bring about the smoldering combustion of the finished cellulosic insulations containing high percentages of chemical add-on (25 percent loading).

3. Additional tests should be conducted to develop data that would allow for the analysis of the relationship that exists between the type of chemical utilized in cellulosic insulations and their acceptable performance in the Attic Floor Radiant Panel apparatus and simulated attic test. 


\section{Page 17}

\section{File USNC97}

4. Additional tests should be conducted to develop data on the effect of the cellulosic insulation when exposed to an overloaded electric wire over an extended period of time.

5. Additional tests should be conducted to develop data that would allow for the analysis of the relationship that may exist between the treating chemical add-on percentages and the smoldering combustion of the finished cellulosic insulation when exposed to a recessed lighting fixture in an overlamped condition $(150 \mathrm{~W})$. 
Page 18

File USNC97

\section{REFERENCES}

1. Anon., Standard for Tests for Surface Burning Characteristics of Building Materials, UL 723-77 (ASTM E-84, NFPA 255, and ANSI A2.5).

2. Anon., Standard Method of Test for Critical Radiant Flux of Exposed Attic Floor Insulation Using a Radiant Heat Energy Source, General Services Administration, HH-I-515D Specification for Insulation Thermal (Loose Fill for Pneumatic or Poured App1ication): Cellulose or Wood Fiber, June 15, 1978.

3. Anon., Amended Interim Standard for Cellulose Insulation, Consumer Product Safety Commission, Federa1 Register, Vo1. 44, No. 47, Friday, July 6, 1979.

4. Anon., Interim Safety Standard for Cellulose Insulation, Consumer Product Safety Commission, Federal Register, Vo1. 43, No. 153, Tuesday, August 8, 1978.

5. Liskey, J.F., Briefing Paper on Proposed Amendment to the Interim Standard for Cellulose Insulation, Consumer Product Safety Commission, January 29, 1979.

6. Gross, D., A Preliminary Study of the Fire Safety of Thermal Insulation For Use In Attics Or Enclosed Spaces In Residential Housing, National Bureau of Standards, NBSIR 78-1497, Ju1y, 1978.

7. Anon., Technical Note on Flammability of Cellulosic Loose Fill Materials Used For Building Insulation During LaboratoryScale And Full-Scale Fire Exposures, Underwriters Laboratories Inc., File Subject 86., Project 78ES518, August 8, 1978.

8. Anon., National Electrical Code 1981 Edition, National Fire Protection Association.

9. National Bureau of Standards, Report No. 80-2085, "Fire Performance of Loose Fill Cellulosic Insulation in Residential Occupancies - A Progress Report," August 1980.

10. National Bureau of Standards, Report No. 81-2350, "Smoldering Combustion Hazards of Thermal Insulation Materials, August, 1981. 
File USNC97

TABLE 1

Chemical Formulation of Test Materials

\begin{tabular}{|c|c|c|c|}
\hline $\begin{array}{c}\text { Material } \\
\text { Identification }\end{array}$ & $\begin{array}{l}\text { Chemical } \\
\text { Formulation }\end{array}$ & $\begin{array}{l}\text { Percent } \\
\text { Chemical } \\
\text { Ioad }\end{array}$ & $\begin{array}{c}\text { Blown } \\
\text { Density, } \\
\text { lb/ } \mathrm{ft}^{3}\end{array}$ \\
\hline A & $\begin{array}{l}\text { Hydrated Alum-40\% } \\
\text { Boric Acid-40\% } \\
\text { Borax }-20 \%\end{array}$ & 22 & 2.2 \\
\hline B & $\begin{array}{l}\text { Hydrated Alum-40\% } \\
\text { Boric Acid-40\% } \\
\text { Borax }-20 \%\end{array}$ & 19 & 1.9 \\
\hline C & $\begin{array}{l}\text { Hydrated Alum-40\% } \\
\text { Boric Acid-40\% } \\
\text { Borax-20\% }\end{array}$ & 13 & 1.7 \\
\hline D & $\begin{array}{l}\text { Hydrated Alum-40\% } \\
\text { Boric Acid-40\% } \\
\text { Borax-20\% }\end{array}$ & 7 & 1.7 \\
\hline$E$ & $\begin{array}{l}\text { Hydrated Alum-40\% } \\
\text { Boric Acid-40\% } \\
\text { Borax-20\% }\end{array}$ & 3 & 1.7 \\
\hline $\mathrm{F}$ & Untreated & None & 1.6 \\
\hline G & $\begin{array}{l}\text { Boric Acid-50\% } \\
\text { Borax }-50 \%\end{array}$ & 16 & 1.9 \\
\hline $\mathrm{H}$ & $\begin{array}{l}\text { Boric Acid-25\% } \\
\text { Borax-50\% } \\
\text { Aluminum Sulfate- }\end{array}$ & 18 & 1.9 \\
\hline
\end{tabular}


File USNC97

TABLE 1 CONT'D

\begin{tabular}{|c|c|c|c|}
\hline $\begin{array}{c}\text { Material } \\
\text { Identification }\end{array}$ & $\begin{array}{l}\text { Chemical } \\
\text { Formulation }\end{array}$ & $\begin{array}{l}\text { Percent } \\
\text { Chemical } \\
\text { Load }\end{array}$ & $\begin{array}{r}\text { Blown } \\
\text { Density, } \\
\text { lb/ft3 } \\
\end{array}$ \\
\hline$I$ & $\begin{array}{l}\text { Borax-25\% } \\
\text { Ammonium Sulfate-75\% }\end{array}$ & 16 & 1.7 \\
\hline $\mathrm{J}$ & $\begin{array}{l}\text { Borid Acid-25\% } \\
\text { Borax-75\% }\end{array}$ & 16 & 1.8 \\
\hline K & Same as "G" & 11 & 1.6 \\
\hline $\mathrm{L}$ & Same as "H" & 12 & 1.7 \\
\hline M & Same as "I" & 11 & 1.7 \\
\hline $\mathrm{N}$ & Same as "J" & 12 & 1.7 \\
\hline $\mathrm{O}$ & Shredded Glass Fiber & $\mathrm{NA}$ & 0.7 \\
\hline $\mathrm{P}$ & Shredded Mineral Wool & $1 \mathrm{NA}$ & 1.9 \\
\hline$Q$ & $\begin{array}{l}\text { Borax }-33 \% \\
\text { Boric Acid-67\% }\end{array}$ & 25 & 2.4 \\
\hline $\mathrm{R}$ & $\begin{array}{l}\text { Borax-67\% } \\
\text { Boric Acid-33\% }\end{array}$ & 25 & 2.2 \\
\hline $\mathrm{s}$ & $\begin{array}{l}\text { Borax-33\% } \\
\text { Boric Acid-33\% } \\
\text { Aluminum Sulfate-33\% }\end{array}$ & 25 & 2.3 \\
\hline $\mathrm{T}$ & $\begin{array}{l}\text { Borax }-20 \% \\
\text { Aluminum Sulfate- } 80 \%\end{array}$ & 25 & 2.1 \\
\hline $\mathrm{V}$ & $\begin{array}{l}\text { Borax }-40 \% \\
\text { Boric Acid-40\% } \\
\text { Aluminum Sulfate-2.0\% }\end{array}$ & 25 & 2.1 \\
\hline W & $\begin{array}{l}\text { Polybor }-67 \% \\
\text { Boric Acid-33응 }\end{array}$ & 25 & 2.2 \\
\hline
\end{tabular}


File USNC97

TABLE 2

$\frac{\text { Atmospheric Conditions }}{\text { Attic }}$

Attic Experiments

\begin{tabular}{|c|c|c|c|c|}
\hline $\begin{array}{l}\text { Test } \\
\text { No. }\end{array}$ & $\begin{array}{r}\text { Material } \\
\text { Identi- } \\
\text { fication } \\
\end{array}$ & $\begin{array}{c}\text { Room } \\
\text { Temperature, } \\
\text { Degrees } \mathrm{F} \\
\end{array}$ & $\begin{array}{l}\text { Relative } \\
\text { Humidity, } \\
\text { Percent } \\
\end{array}$ & $\begin{array}{l}\text { Ignition } \\
\text { Source }\end{array}$ \\
\hline 1 & A & 75 & 50 & Alc. Spill \\
\hline 2 & B & 75 & 52 & Alc. Spill \\
\hline 3 & C & 78 & 54 & Alc. Spill \\
\hline 4 & D & 63 & 65 & Alc. Spill \\
\hline 5 & $\mathrm{E}$ & 64 & 41 & Alc. Spill \\
\hline 6 & $\mathrm{~F}$ & 77 & 74 & Alc. Spill \\
\hline 7 & $\bar{A}$ & 85 & 64 & Cigarette \\
\hline 8 & B & 85 & 64 & Cigarette \\
\hline 9 & C & 84 & 64 & Cigarette \\
\hline 10 & D & 84 & 64 & Cigarette \\
\hline 11 & $\mathrm{E}$ & 85 & 48 & Cigarette \\
\hline 12 & F & 85 & 48 & Cigarette \\
\hline 13 & B & 87 & 65 & $\begin{array}{l}\text { Alc. Spill- } \\
\text { Radiant }\end{array}$ \\
\hline 14 & C & 85 & 47 & $\begin{array}{l}\text { Alc-Spill- } \\
\text { Radiant }\end{array}$ \\
\hline 15 & B & 77 & 65 & Torch \\
\hline 16 & C & 77 & 60 & Torch \\
\hline 17 & 0 & 78 & 50 & Alc. Spill \\
\hline 18 & $\mathrm{P}$ & 78 & 50 & Alc. Spill \\
\hline 19 & $\mathrm{~J}$ & 86 & 70 & Cigarette \\
\hline 20 & I & 86 & 70 & Cigarette \\
\hline 21 & $\mathrm{H}$ & 73 & 75 & Cigarette \\
\hline 22 & B & 67 & 75 & $\begin{array}{l}\text { Fixture- } \\
\text { Rated }\end{array}$ \\
\hline 23 & $\mathrm{H}$ & 67 & 75 & $\begin{array}{l}\text { Fixture- } \\
\text { Rated }\end{array}$ \\
\hline 24 & $\mathrm{H}$ & 70 & 76 & Alc. Spill \\
\hline 25 & $I$ & 74 & 60 & Alc. Spill \\
\hline 26 & J & 74 & 84 & Alc. Spill \\
\hline 27 & $\mathrm{H}$ & 74 & 84 & $\begin{array}{l}\text { Fixture- } \\
\text { Over-rated }\end{array}$ \\
\hline 28 & B & $74^{\circ}$ & 84 & $\begin{array}{l}\text { Fixture- } \\
\text { Over-rated }\end{array}$ \\
\hline 29 & G & 75 & 72 & Alc. Spill \\
\hline 30 & $\mathrm{~N}$ & 75 & 72 & Alc. Spill \\
\hline
\end{tabular}


File USNC97

TABIE 2 CONT'D

\begin{tabular}{|c|c|c|c|c|}
\hline $\begin{array}{r}\text { Test } \\
\text { No. }\end{array}$ & $\begin{array}{r}\text { Material } \\
\text { Identi- } \\
\text { fication } \\
\end{array}$ & $\begin{array}{c}\text { Room } \\
\text { Temperature, } \\
\text { Degrees F } \\
\end{array}$ & $\begin{array}{l}\text { Relative } \\
\text { Humidity, } \\
\text { Percent } \\
\end{array}$ & $\begin{array}{l}\text { Ignition } \\
\text { Source }\end{array}$ \\
\hline 31 & G & 72 & 58 & $\begin{array}{l}\text { Fixture- } \\
\text { Rated }\end{array}$ \\
\hline 32 & $I$ & 72 & 58 & $\begin{array}{l}\text { Fixture- } \\
\text { Rated }\end{array}$ \\
\hline 33 & $\mathrm{~L}$ & 73 & 68 & Alc. Spill \\
\hline 34 & G & 73 & 68 & $\begin{array}{l}\text { Fixture- } \\
\text { Over-rated }\end{array}$ \\
\hline 35 & $I$ & 73 & 68 & $\begin{array}{l}\text { Fixture- } \\
\text { Over-rated }\end{array}$ \\
\hline 36 & $\mathrm{~K}$ & 68 & 62 & Alc. Spill \\
\hline 37 & M & 68 & 62 & Alc. Spill \\
\hline 38 & G & 77 & 68 & Cigarette \\
\hline 39 & $\mathrm{~J}$ & 77 & 68 & $\begin{array}{l}\text { Fixture- } \\
\text { Rated }\end{array}$ \\
\hline 40 & $\mathrm{~J}$ & 76 & 60 & $\begin{array}{l}\text { Fixture- } \\
\text { Over-rated }\end{array}$ \\
\hline 41 & $\mathrm{~J}$ & 72 & 62 & $\begin{array}{l}\text { Overheated } \\
\text { Wire }\end{array}$ \\
\hline 42 & $\mathrm{~S}$ & 79 & 55 & Alc. Spill \\
\hline 43 & $\mathrm{~T}$ & 79 & 55 & Alc. Spill \\
\hline 44 & $\mathbf{T}$ & 78 & 57 & Cigarette \\
\hline 45 & $\mathrm{~S}$ & 85 & 57 & Cigarette \\
\hline 46 & W & 85 & 57 & Alc. Spill \\
\hline 47 & $\mathrm{R}$ & 76 & 88 & Alc. Spill \\
\hline 48 & W & 76 & 88 & Cigarette \\
\hline 49 & $\mathbf{R}$ & 84 & 67 & Cigarette \\
\hline 50 & V & 84 & 67 & Alc. Spill \\
\hline 51 & $Q$ & 84 & 67 & Alc. Spill \\
\hline 52 & V & 79 & 84 & Cigarette \\
\hline 53 & $Q$ & 79 & 84 & Cigarette \\
\hline 54 & $\mathrm{R}$ & 74 & 87 & Cigarette \\
\hline 55 & V & 80 & 58 & $\begin{array}{c}\text { Fixture- } \\
\text { Rated }\end{array}$ \\
\hline 56 & $\mathbf{S}$ & 80 & 58 & $\begin{array}{l}\text { Fixture- } \\
\text { Rated }\end{array}$ \\
\hline 57 & $Q$ & 80 & 58 & $\begin{array}{l}\text { Fixture- } \\
\text { Rated }\end{array}$ \\
\hline 58 & $\mathrm{~T}$ & 80 & 58 & $\begin{array}{l}\text { Fixture- } \\
\text { Rated }\end{array}$ \\
\hline 59 & V & 74 & 82 & $\begin{array}{l}\text { Fixture- } \\
\text { Rated. }\end{array}$ \\
\hline
\end{tabular}


File USNC97

TABLE 2 CONT'D

\begin{tabular}{|c|c|c|c|c|}
\hline $\begin{array}{l}\text { Test } \\
\text { No. }\end{array}$ & $\begin{array}{r}\text { Material } \\
\text { Identi- } \\
\text { fication } \\
\end{array}$ & $\begin{array}{c}\text { Room } \\
\text { Temperature, } \\
\text { Degrees } \mathrm{F} \\
\end{array}$ & $\begin{array}{l}\text { Relative } \\
\text { Humidity, } \\
\text { Percent } \\
\end{array}$ & $\begin{array}{l}\text { Ignition } \\
\text { Source }\end{array}$ \\
\hline 60 & $S$ & 74 & 82 & $\begin{array}{l}\text { Fixture- } \\
\text { Rated }\end{array}$ \\
\hline 61 & Q & 74 & 82 & $\begin{array}{l}\text { Fixture- } \\
\text { Rated }\end{array}$ \\
\hline 62 & $\mathrm{~T}$ & 74 & 82 & $\begin{array}{l}\text { Fixture- } \\
\text { Rated }\end{array}$ \\
\hline 63 & $W$ & 74 & 52 & $\begin{array}{l}\text { Fixture- } \\
\text { Rated }\end{array}$ \\
\hline 64 & $W$ & 74 & 52 & $\begin{array}{l}\text { Fixture- } \\
\text { Rated }\end{array}$ \\
\hline 65 & $\mathrm{R}$ & 74 & 52 & $\begin{array}{l}\text { Fixture- } \\
\text { Over-rated }\end{array}$ \\
\hline 66 & $\mathrm{R}$ & 74 & 52 & $\begin{array}{l}\text { Fixture- } \\
\text { Rated }\end{array}$ \\
\hline
\end{tabular}


TABLE 3

Iaboratory Test Results

Installed

Blown

Material

Identification

A

B

C

D

$\mathrm{E}$

$\mathrm{F}$

G

$\mathrm{H}$

J

$\mathrm{K}$

I

N

$\mathrm{O}$

$\mathrm{P}$

$Q$

R

$\mathrm{T}$

V
Density
$1 \mathrm{~b} / \mathrm{ft}^{3}$

2.2
2.0

1.7

1.7

1.7

1.6

1.9

1.9

1.7

1.8

1.6

1.7

1.7

1.7

0.7

1.9

2.4

2.2

2.3

2.1

2.1

2.2

\begin{tabular}{|c|c|c|}
\hline $\begin{array}{l}\text { Percent } \\
\text { Chemical }\end{array}$ & \multicolumn{2}{|c|}{$\begin{array}{l}\text { 25-Ft Funnel Test } \\
\text { Flame Spread }\end{array}$} \\
\hline Loading & Test 1 & Test 2 \\
\hline 22 & 22.6 & 25.9 \\
\hline 19 & 35.6 & 38.5 \\
\hline 13 & 48.7 & 39.1 \\
\hline 7 & 51.4 & 47.3 \\
\hline 3 & 61.1 & 58.4 \\
\hline- & 71.7 & 63.8 \\
\hline 16 & 24.8 & 25.3 \\
\hline 18 & 33.9 & 37.7 \\
\hline 16 & 32.3 & 31.9 \\
\hline 16 & 39.1 & 35.6 \\
\hline 11 & 45.4 & 48.8 \\
\hline 12 & 45.2 & 42.0 \\
\hline 11 & 38.7 & 39.0 \\
\hline 12 & 52.3 & $\mathrm{NC}+$ \\
\hline NA & 9.6 & 9.8 \\
\hline NA & 3.0 & 3.0 \\
\hline 25 & 22.7 & $\mathrm{NC}+$ \\
\hline 25 & 19.3 & $\mathrm{NC}+$ \\
\hline 25 & 19.4 & $\mathrm{NC}+$ \\
\hline 25 & 22.8 & $\mathrm{NC}+$ \\
\hline 25 & 19.2 & $\mathrm{NC}+$ \\
\hline 25 & 21.9 & $\mathrm{NC}+$ \\
\hline
\end{tabular}

Attic Floor Radiant

Panel Test

$\mathrm{CRF}, \mathrm{W} / \mathrm{cm}^{2}$

\begin{tabular}{|c|c|c|}
\hline \multicolumn{3}{|c|}{$\mathrm{CRF}, \mathrm{W} / \mathrm{cm}$} \\
\hline Test 1 & Test 2 & Test 3 \\
\hline 0.14 & 0.13 & 0.13 \\
\hline 0.10 & 0.10 & 0.10 \\
\hline 0.10 & 0.10 & 0.10 \\
\hline 0.10 & 0.10 & 0.10 \\
\hline
\end{tabular}

$\mathrm{NC}++\mathrm{NC}++\quad \mathrm{NC}++$

$\mathrm{NC}+\mathrm{NC}+\mathrm{NC}++$

$\begin{array}{lll}0.16 & 0.15 & 0.15\end{array}$

$0.11 \quad 0.10 \quad 0.10$

$\begin{array}{lll}0.10 & 0.10 & 0.10\end{array}$

$\begin{array}{lll}0.11 & 0.10 & 0.10\end{array}$

$\begin{array}{lll}0.10 & 0.10 & 0.10\end{array}$

$\begin{array}{lll}0.10 & 0.10 & \mathrm{NC}+\end{array}$

$0.10 \quad 0.10 \quad \mathrm{NC+}$

$\begin{array}{llll}0.10 & 0.10 & \mathrm{NCH}\end{array}$

$\begin{array}{lll}1.2 & 1.2 & 1.2\end{array}$

$\begin{array}{lll}1.2 & 1.2 & 1.2\end{array}$

$\begin{array}{lll}0.17 & 0.16 & 0.17\end{array}$

$\begin{array}{lll}0.15 & 0.14 & 0.16\end{array}$

$\begin{array}{lll}0.11 & 0.14 & 0.14\end{array}$

$\begin{array}{lll}0.10 & 0.10 & 0.10\end{array}$

$\begin{array}{lll}0.10 & 0.13 & 0.11\end{array}$

$\begin{array}{lll}0.17 & 0.18 & 0.18\end{array}$

$\mathrm{NC}+=$ Not conducted .

$\mathrm{NC}++=$ Not conducted based on preceding test results.

NA $=$ Not applicable 
TABLE 4

Results of Simulated Attic Tests

(Initial Ambient Temperature of $150^{\circ} \mathrm{F}$ )

$\begin{array}{lll} & \text { Maximum } \\ \text { Average } & \text { Extent Affected } & \\ \text { Critical Rate of }\end{array}$

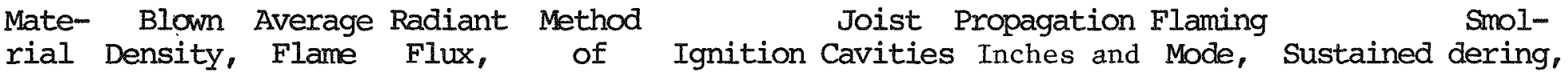

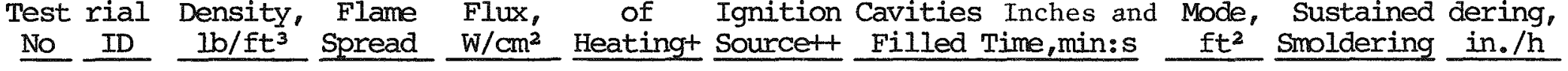

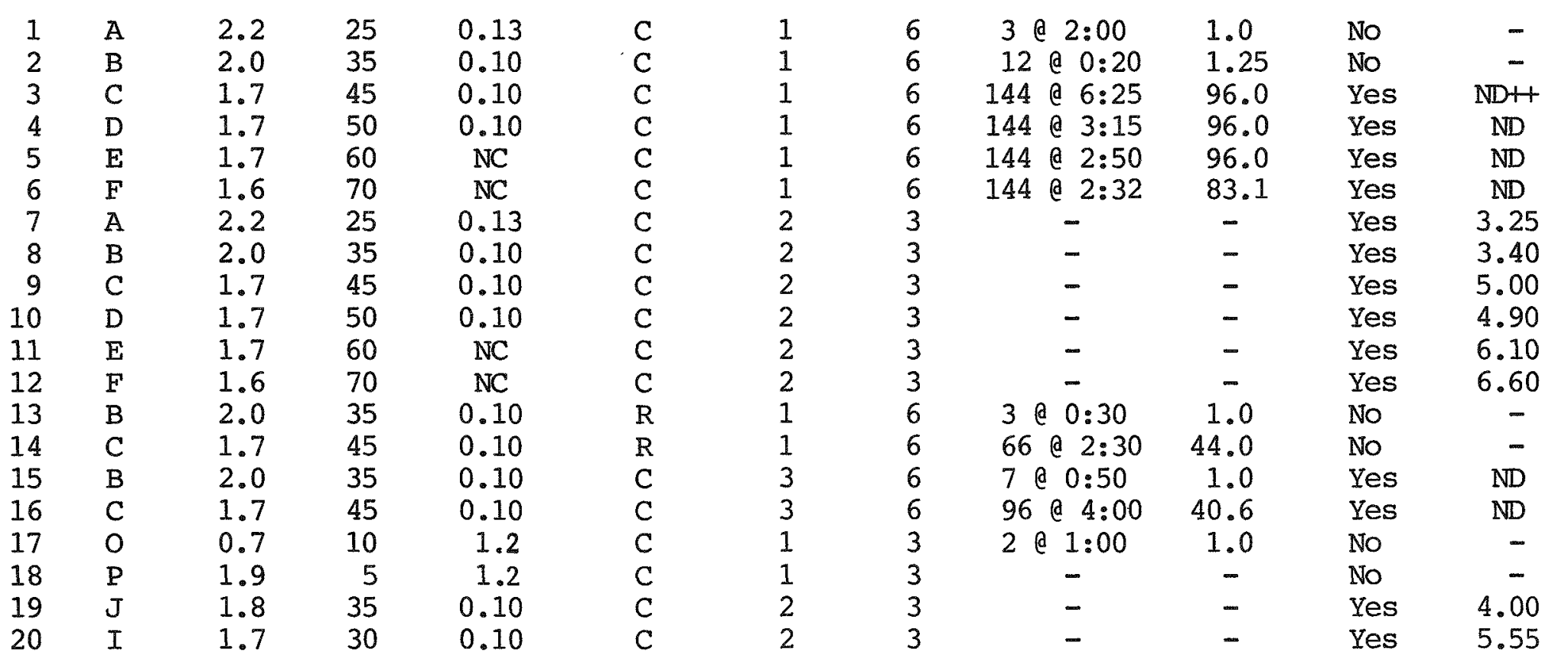


TABLE 4 CONT'D

\begin{tabular}{|c|c|c|c|c|c|c|c|c|c|c|c|}
\hline $\begin{array}{c}\text { Test } \\
\text { No }\end{array}$ & $\begin{array}{l}\text { Mate- } \\
\text { rial } \\
\text { ID } \\
\end{array}$ & $\begin{array}{c}\text { Blown } \\
\text { Density, } \\
\text { lb/ } \mathrm{ft}^{3}\end{array}$ & $\begin{array}{c}\text { Average } \\
\text { Flame } \\
\text { Spread }\end{array}$ & $\begin{array}{c}\text { Average } \\
\text { Critical } \\
\text { Radiant } \\
\text { Flux, } \\
\text { W/cm } \\
\end{array}$ & $\begin{array}{l}\text { Method } \\
\text { of } \\
\text { Heatingt }\end{array}$ & $\begin{array}{l}\text { Ignition } \\
\text { Sourcet+ }\end{array}$ & $\begin{array}{c}\text { No. Of } \\
\text { Joist } \\
\text { Cavities } \\
\text { Filled } \\
\end{array}$ & $\begin{array}{l}\text { Maximum } \\
\text { Extent } \\
\text { Of Flame } \\
\text { Propagation } \\
\text { s In, and } \\
\text { Time,min:s }\end{array}$ & $\begin{array}{c}\text { Affected } \\
\text { Area } \\
\text { Flaming } \\
\text { Mode, } \\
\mathrm{ft}^{2} \\
\end{array}$ & $\begin{array}{l}\text { Sustained } \\
\text { Smoldering } \\
\end{array}$ & $\begin{array}{r}\text { Rate O } \\
\text { Smol- } \\
\text { dering } \\
\text { in./h } \\
\end{array}$ \\
\hline 21 & $\mathrm{H}$ & 1.9 & 35 & 0.10 & C & 2 & 6 & - & - & Yes & 4.75 \\
\hline 22 & B & 2.0 & 35 & 0.10 & $\mathrm{C}$ & 4 & 3 & - & - & No & - \\
\hline 23 & $\mathrm{H}$ & 1.9 & 35 & 0.10 & $\mathrm{C}$ & 4 & 3 & - & - & No & - \\
\hline 24 & $\mathrm{H}$ & 1.9 & 35 & 0.10 & C & 1 & 6 & 3 a 1:00 & 1.0 & Yes & ND \\
\hline 25 & $I$ & 1.7 & 30 & 0.10 & C & 1 & 6 & 30 e $1: 15$ & 4.7 & Yes & $\mathrm{ND}$ \\
\hline 26 & $\mathrm{~J}$ & 1.8 & 35 & 0.10 & $\mathrm{C}$ & 1 & 6 & $2.5 \Leftrightarrow 0: 30$ & 1.0 & No & - \\
\hline 27 & $\mathrm{H}$ & 1.9 & 35 & 0.10 & $\mathrm{C}$ & 5 & 3 & - & - & Yes & 7.09 \\
\hline 28 & B & 2.0 & 35 & 0.10 & C & 5 & 3 & - & - & Yes & 3.40 \\
\hline 29 & G & 1.9 & 25 & 0.15 & $\mathrm{C}$ & 1 & 6 & 3 a $0: 30$ & 1.0 & No & - \\
\hline 30 & $\mathrm{~N}$ & 1.7 & 50 & 0.10 & $\mathrm{C}$ & 1 & 6 & 66 @ $3: 15$ & 31.3 & Yes & ND \\
\hline 31 & G & 1.9 & 25 & 0.15 & $\mathrm{C}$ & 4 & 3 & - & - & No & - \\
\hline 32 & I & 1.7 & 30 & 0.10 & C & 4 & 3 & - & - & No & - \\
\hline 33 & $\mathrm{~L}$ & 1.7 & 45 & 0.10 & C & 1 & 6 & $90 \propto 6: 00$ & 32.3 & Yes & ND \\
\hline 34 & G & 1.9 & 25 & $0 . ! 5$ & C & 5 & 3 & - & - & Yes & 4.20 \\
\hline 35 & I & 1.7 & 30 & 0.10 & $\mathrm{C}$ & 5 & 3 & - & - & Yes & 5.32 \\
\hline 36 & $\mathrm{~K}$ & 1.6 & 45 & 0.10 & $\mathrm{C}$ & 1 & 6 & 144 e $6: 00$ & 74.6 & Yes & ND \\
\hline 37 & M & 1.7 & 40 & 0.10 & $\mathrm{C}$ & 1 & 6 & $144 @ 3: 45$ & 76.0 & Yes & $\mathrm{ND}$ \\
\hline 38 & G & 1.9 & 25 & 0.15 & C & 2 & 3 & - & - & Yes & 3.80 \\
\hline 39 & $\mathrm{~J}$ & 1.8 & 35 & 0.10 & $\mathrm{C}$ & 4 & 3 & - & - & No & - \\
\hline 40 & $\mathrm{~J}$ & 1.8 & 35 & 0.10 & C & 5 & 3 & - & - & Yes & 4.30 \\
\hline 41 & $\mathrm{~J}$ & 1.3 & 35 & 0.10 & $\mathrm{C}$ & 6 & 3 & - & - & Yes & 4.30 \\
\hline 42 & $\mathrm{~s}$ & 2.3 & 20 & 0.13 & C & 1 & 3 & $2.5 @ 0: 30$ & 1.0 & No & - \\
\hline 43 & $\mathbf{T}$ & 2.1 & 25 & 0.10 & C & 1 & 3 & $2.75 @ 0: 30$ & 1.0 & No & - \\
\hline 44 & $\mathbf{T}$ & 2.1 & 25 & 0.10 & C & 2 & 3 & - & - & No & - \\
\hline 45 & $\mathbf{S}$ & 2.3 & 20 & 0.13 & C & 2 & 3 & - & - & No & - \\
\hline 46 & W & 2.2 & 20 & 0.18 & C & 1 & 3 & $3.0 @ 0: 45$ & 1.0 & No & - \\
\hline
\end{tabular}


TABLE 4 CONT'D

\begin{tabular}{|c|c|c|c|c|c|c|c|c|c|c|c|c|}
\hline $\begin{array}{r}\text { Test } \\
\text { No. }\end{array}$ & $\begin{array}{l}\text { Mate- } \\
\text { rial } \\
\text { ID } \\
\end{array}$ & $\begin{array}{l}\text { Blown } \\
\text { Density } \\
\text { lb/ft }{ }^{3} \\
\end{array}$ & $\begin{array}{l}\text { Average } \\
\text { Flame } \\
\text { Spread } \\
\end{array}$ & $\begin{array}{l}\text { Average } \\
\text { Critical } \\
\text { Radiant } \\
\text { Flux, } \\
W / \mathrm{cm}^{2} \\
\end{array}$ & $\begin{array}{l}\text { Method } \\
\text { of } \\
\text { Heating+ } \\
\end{array}$ & $\begin{array}{l}\text { Ignition } \\
\text { Sourcet+ }\end{array}$ & $\begin{array}{l}\text { No. of } \\
\text { Joist } \\
\text { Cavities } \\
\text { Filled } \\
\end{array}$ & $\begin{array}{r}\text { Maxi } \\
\text { Ext } \\
\text { Of } \mathrm{F} 1 \\
\text { Propa } \\
\text { Inch } \\
\text { Time, }\end{array}$ & $\begin{array}{l}\text { Imum } \\
\text { sent } \\
\text { Lame } \\
\text { gation } \\
\text { ies and } \\
\text { Min:s }\end{array}$ & $\begin{array}{l}\text { Affected } \\
\text { Area } \\
\text { Flaming } \\
\text { Mode, } \\
\text { ft }^{2} \\
\end{array}$ & $\begin{array}{l}\text { Sus- } \\
\text { tained } \\
\text { Smol- } \\
\text { dering }\end{array}$ & $\begin{array}{l}\text { Rate of } \\
\text { Smol- } \\
\text { dering, } \\
\text { in./h } \\
\end{array}$ \\
\hline 47 & $\mathbf{R}$ & 2.2 & 20 & 0.15 & $\mathrm{C}$ & 1 & 3 & 3.5 & $0: 15$ & 1.0 & No & - \\
\hline 48 & W & 2.2 & 20 & 0.18 & $\mathrm{C}$ & 2 & 3 & - & - & - & No & - \\
\hline 49 & $\mathrm{R}$ & 2.2 & 20 & 0.15 & $\mathrm{C}$ & 2 & 3 & - & - & - & Yes & 3.43 \\
\hline 50 & V & 2.1 & 20 & 0.11 & $\mathrm{C}$ & 1 & 3 & 4.25 & (a) $1: 00$ & 1.0 & No & - \\
\hline 51 & $Q$ & 2.4 & 25 & 0.17 & C & 1 & 3 & 5.25 & (c) $0: 15$ & 1.0 & No & - \\
\hline 52 & V & 2.1 & 20 & 0.11 & $\mathrm{C}$ & 2 & 3 & - & - & - & No & - \\
\hline 53 & Q & 2.4 & 25 & 0.17 & C & 2 & 3 & - & - & - & No & - \\
\hline 54 & $\mathrm{R}$ & 2.2 & 20 & 0.15 & $\mathrm{C}$ & 2 & 3 & - & - & - & Yes & 3.43 \\
\hline 55 & V & 2.1 & 20 & 0.11 & $\mathrm{C}$ & 4 & 3 & - & - & - & No & - \\
\hline 56 & S & 2.3 & 20 & 0.13 & C & 4 & 3 & - & - & - & No & - \\
\hline 57 & $Q$ & 2.4 & 25 & 0.17 & C & 4 & 3 & - & - & - & No & - \\
\hline 58 & $\mathrm{~T}$ & 2.1 & 25 & 0.10 & C & 4 & 3 & - & - & - & No & - \\
\hline 59 & V & 2.1 & 20 & 0.11 & C & 5 & 3 & - & - & - & Yes & 3.76 \\
\hline 60 & $\mathrm{~S}$ & 2.3 & 20 & 0.13 & $\mathrm{x}$ & 5 & 3 & - & - & - & Yes & 3.70 \\
\hline 61 & Q & 2.4 & 25 & 0.17 & C & 5 & 3 & - & - & - & Yes & 2.53 \\
\hline 62 & $\mathrm{~T}$ & 2.1 & 25 & 0.10 & C & 5 & 3 & - & - & - & Yes & 2.48 \\
\hline 63 & W & 2.2 & 20 & 0.18 & C & 5 & 3 & - & - & - & Yes & 3.70 \\
\hline 64 & W & 2.2 & 20 & 0.18 & C & 4 & 3 & - & - & - & No & - \\
\hline 65 & $\mathrm{R}$ & 2.2 & 20 & 0.15 & $\mathrm{C}$ & 5 & 3 & - & - & - & Yes & 1.92 \\
\hline 66 & $\mathbf{R}$ & 2.2 & 20 & 0.15 & C & 4 & 3 & - & - & - & No & - \\
\hline \multicolumn{5}{|c|}{$\begin{aligned}+-\mathrm{C} & =\text { Convective } \\
\mathrm{R} & =\text { Radiant }\end{aligned}$} & \multicolumn{7}{|c|}{$\begin{array}{l}6 \text { = Overheated wire } \\
N C \text { - Not conducted } \\
N D \text { - Not determined }\end{array}$} & \\
\hline
\end{tabular}


File USNC97

TABLE 5

Maximm Temperature of Recessed Fixture

\begin{tabular}{|c|c|c|c|}
\hline $\begin{array}{r}\text { Test } \\
\text { No. }\end{array}$ & Material & Test Method & $\begin{array}{l}\text { Maximum } \\
\text { Temperature } \\
\text { on Fixture, } \\
{ }^{\circ} \mathrm{F} \text { (Prior To } \\
\text { Smoldering }\end{array}$ \\
\hline 22 & B & Rated $60 \mathrm{~W}$ & $153+$ \\
\hline 23 & $\mathrm{H}$ & Rated $60 \mathrm{~W}$ & 200 \\
\hline 27 & $\mathrm{H}$ & Overrated $150 \mathrm{~W}$ & 550 \\
\hline 28 & B & Overrated $150 \mathrm{~W}$ & 535 \\
\hline 31 & G & Rated $60 \mathrm{~W}$ & 290 \\
\hline 32 & I & Rated $60 \mathrm{~W}$ & 293 \\
\hline 34 & G & Overrated $150 \mathrm{~W}$ & 530 \\
\hline 35 & I & Overrated $150 \mathrm{~W}$ & 480 \\
\hline 39 & J & Rated $60 \mathrm{~W}$ & 305 \\
\hline 40 & $\mathrm{~J}$ & Overrated $150 \mathrm{~W}$ & 610 \\
\hline 55 & $\mathrm{~V}$ & Rated $60 \mathrm{~W}$ & 290 \\
\hline 56 & $S$ & Rated $60 \mathrm{~W}$ & 290 \\
\hline 57 & Q & Rated $60 \mathrm{~W}$ & 315 \\
\hline 58 & $\mathrm{~T}$ & Rated $60 \mathrm{~W}$ & 315 \\
\hline 59 & $\mathrm{~V}$ & Overrated $150 \mathrm{~W}$ & 550 \\
\hline 60 & $S$ & Overrated $150 \mathrm{~W}$ & 540 \\
\hline 61 & $Q$ & Overrated $150 \mathrm{~W}$ & 550 \\
\hline 62 & $\tilde{T}$ & Overrated $150 \mathrm{~W}$ & 550 \\
\hline 63 & W & Overrated $150 \mathrm{~W}$ & 545 \\
\hline 64 & $W$ & Rated $60 \mathrm{~W}$ & 320 \\
\hline 65 & $\mathrm{R}$ & Overrated $150 \mathrm{~W}$ & 545 \\
\hline 66 & R & Rated $60 \mathrm{~W}$ & 300 \\
\hline
\end{tabular}




\section{Page 29}

File USNC97

\section{TABLE 6}

Overloaded Electric Wire Temperatures

Test No. 41

Time,

h:m

Material J(16 Percent Add-On)

$0: 00$

$0: 30$

$1: 00$

$1: 30$

2:00

$2: 30$

$3: 00$

$3: 30$

$4: 00$

$4: 30$

5:00

$5: 30$

$6: 00$

$6: 30$

$7: 00$

$7: 45$

$8: 00$

\begin{tabular}{l} 
Amperage \\
\hline 48 \\
48 \\
48 \\
47.5 \\
47.5 \\
47.5 \\
47.5 \\
47.5 \\
47.5 \\
47.5 \\
48 \\
48 \\
48 \\
48 \\
48 \\
48 \\
48
\end{tabular}

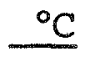

$\stackrel{\circ}{\circ}$

$52 \quad 126$

$124 \quad 255$

$138 \quad 280$

$144 \quad 291$

$147 \quad 297$

$148 \quad 298$

$149 \quad 300$

$150 \quad 302$

$150 \quad 302$

$150 \quad 302$

$152 \quad 306$

$153 \quad 307$

$154 \quad 309$

$155 \quad 311$

$155 \quad 311$

$157 \quad 314$

$157 \quad 315$ 


\section{SIMULATED ATTIC}

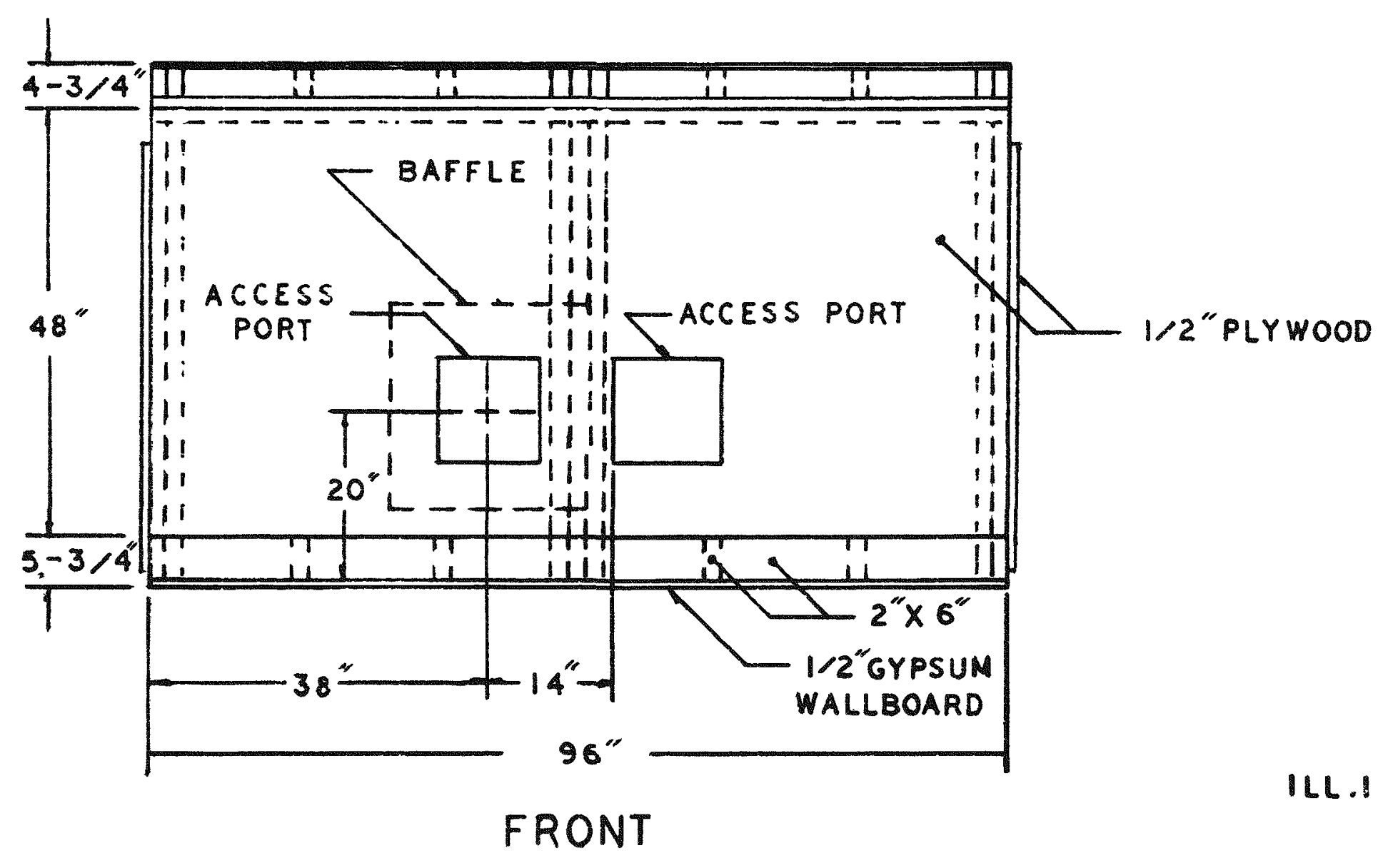




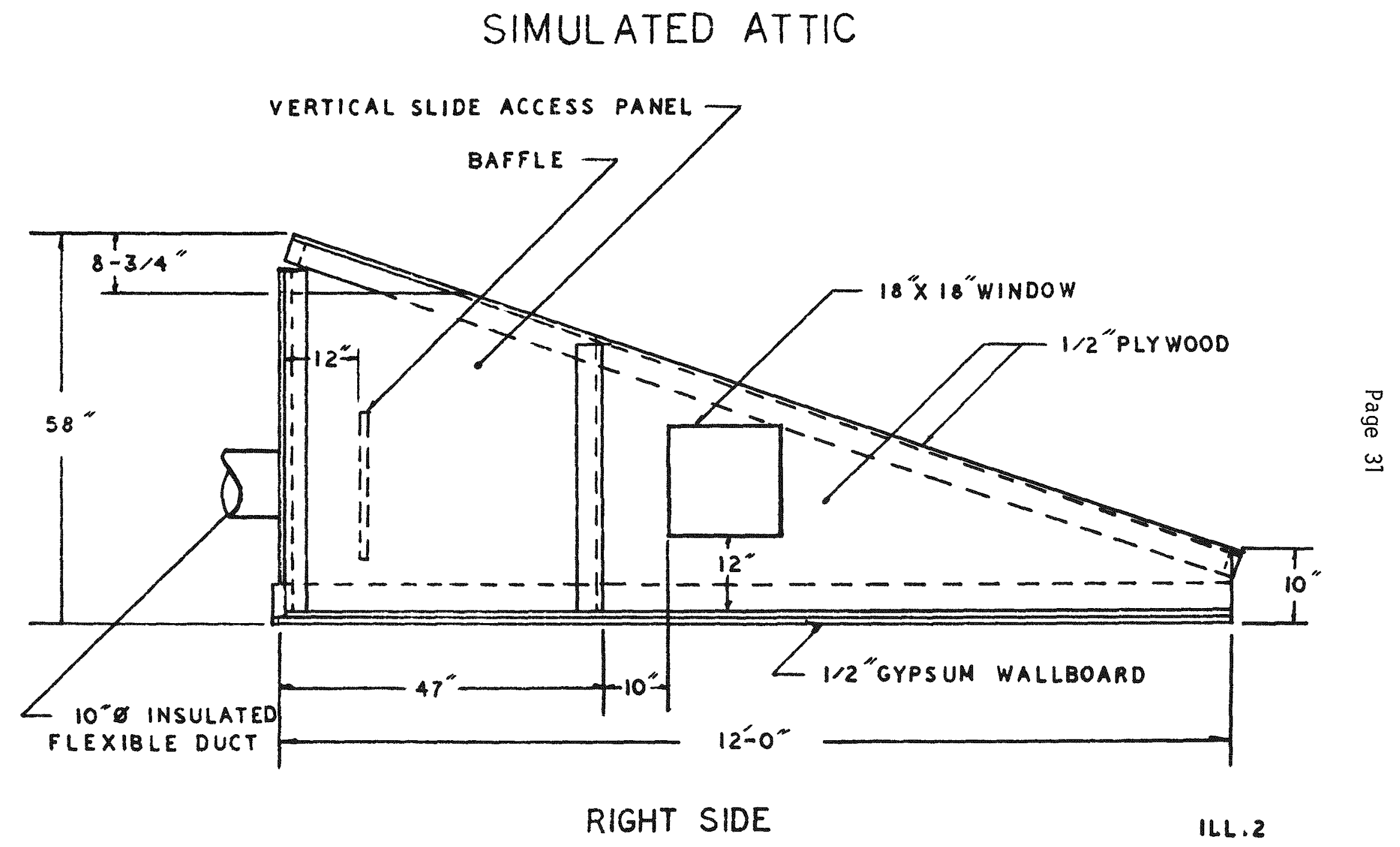




\section{SIMULATED ATTIC}

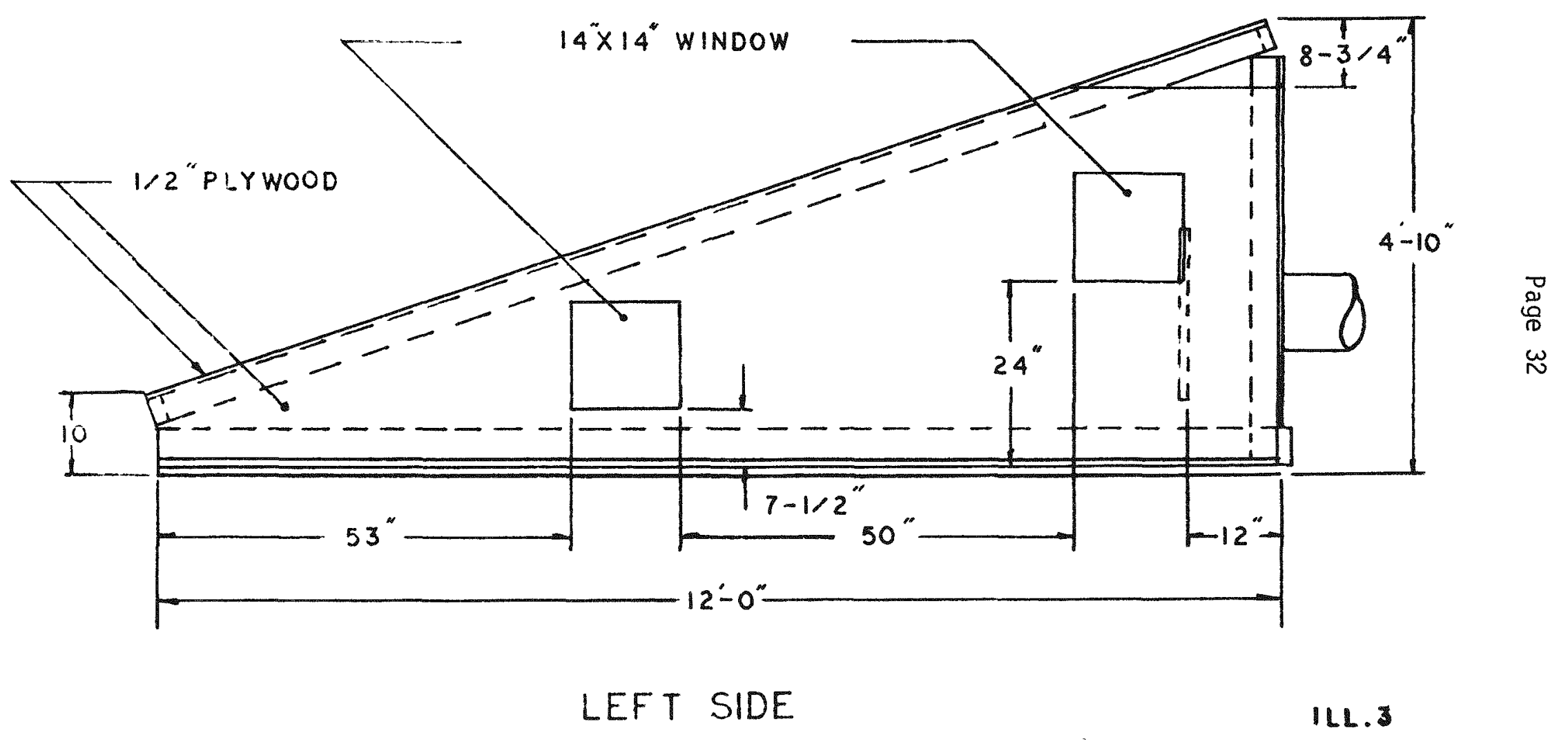


Page 33

RADIANT PRE-HEATING ASSEMBLY
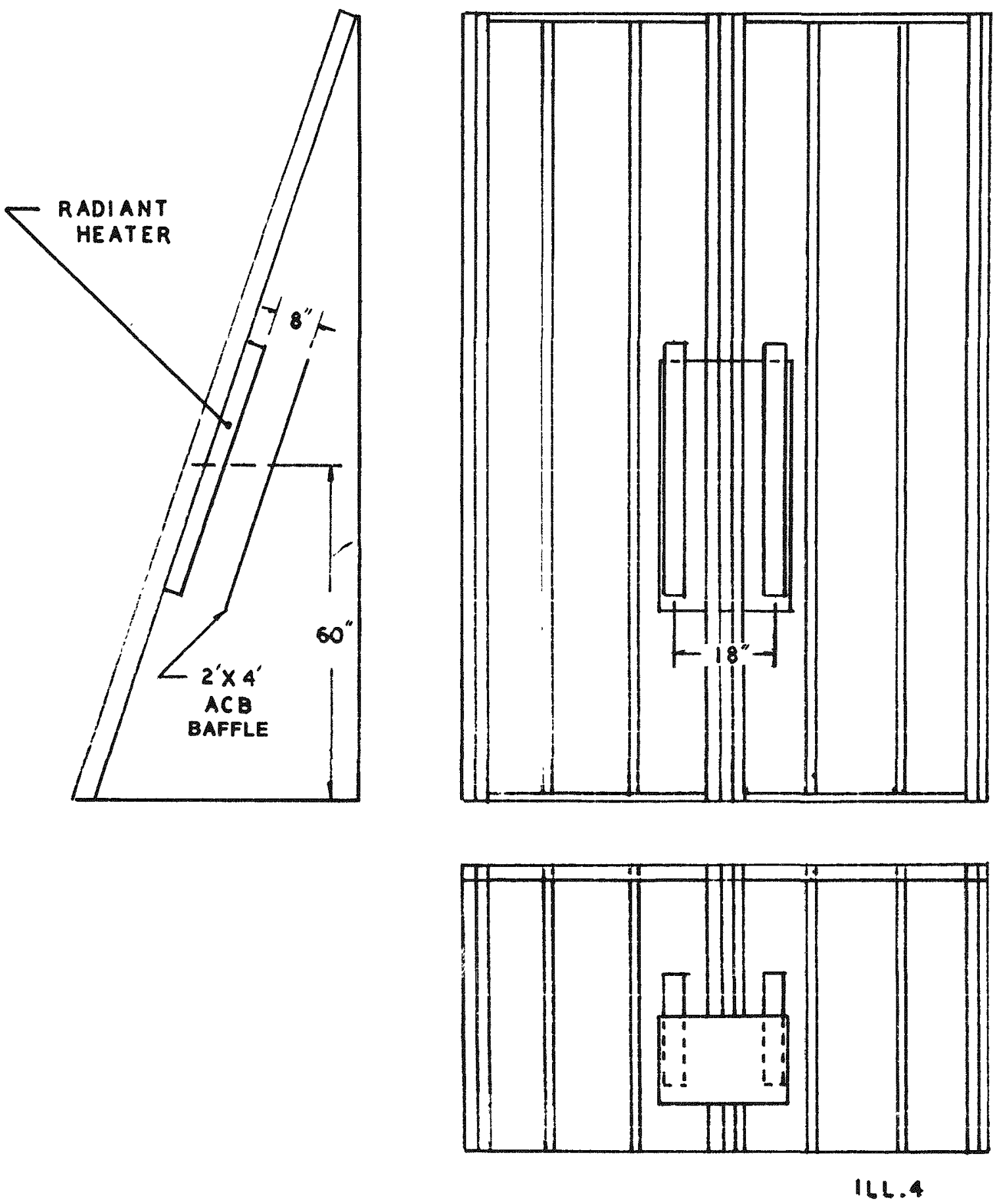
Page 34

ATTIC THERMOCOUPLE LOCATIONS
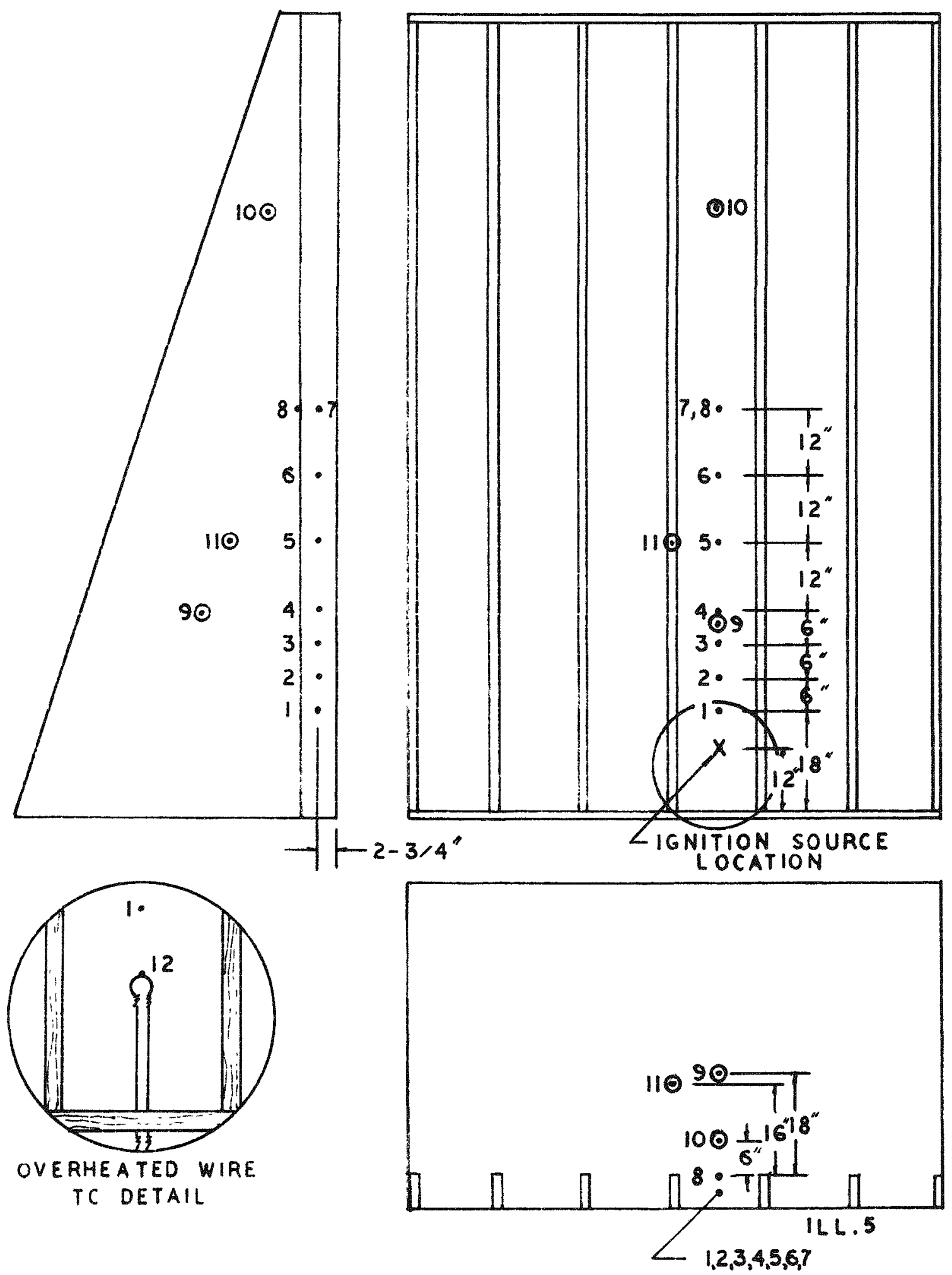
FLAME SPREAD vs. PERCENT CHEMICAL ADD-ON

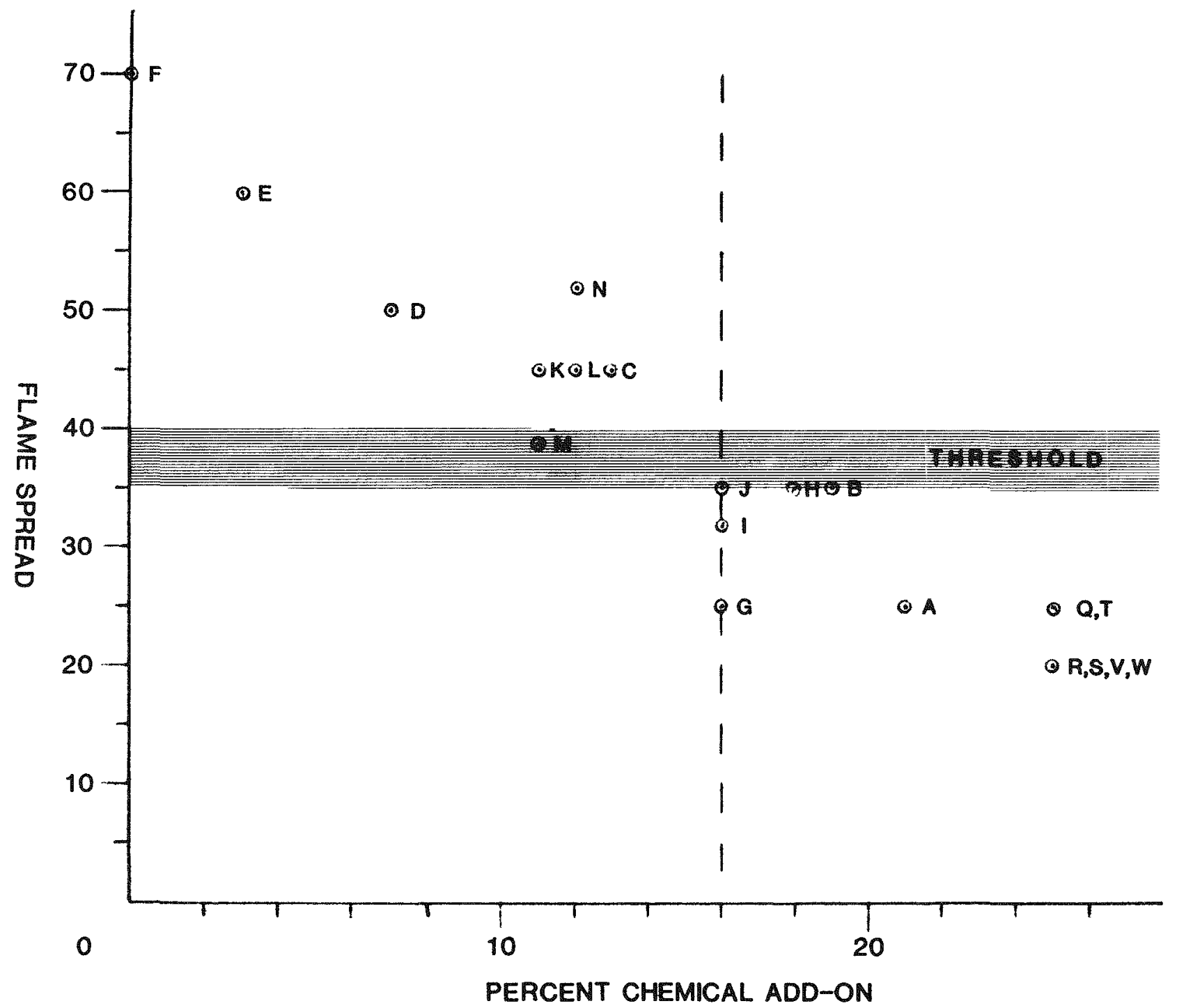


CRITICAL RADIANT FLUX vS. PERCENT CHEMICAL ADD-ON

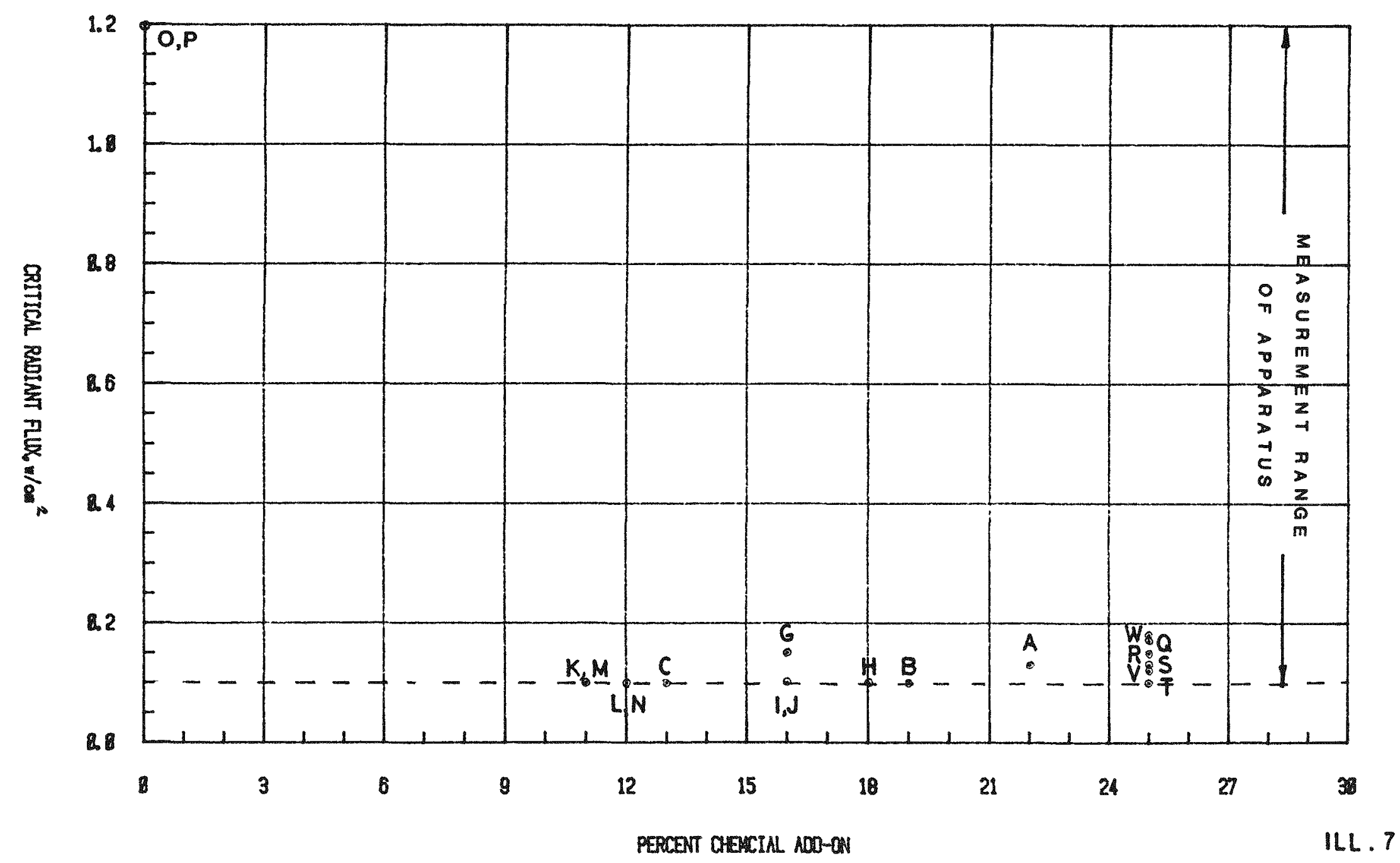


FLAME SPREAD vs. CRITICAL RADIANT FLUX

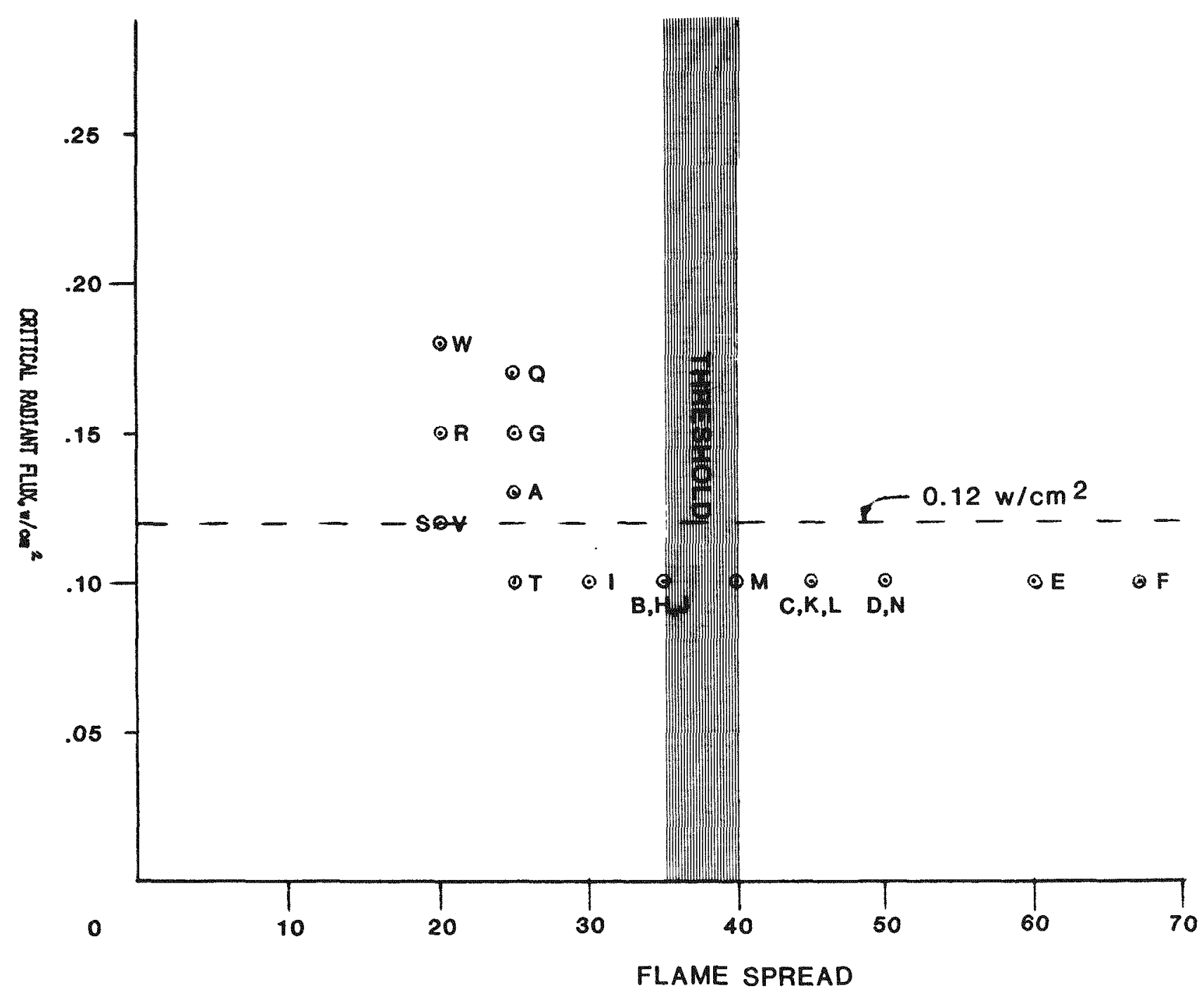


FLAME SPREAD vs. AFFECTED AREA SIMULATED ATTIC TESTS

ALCOHOL SPILL

CONVECTIVE HEATING

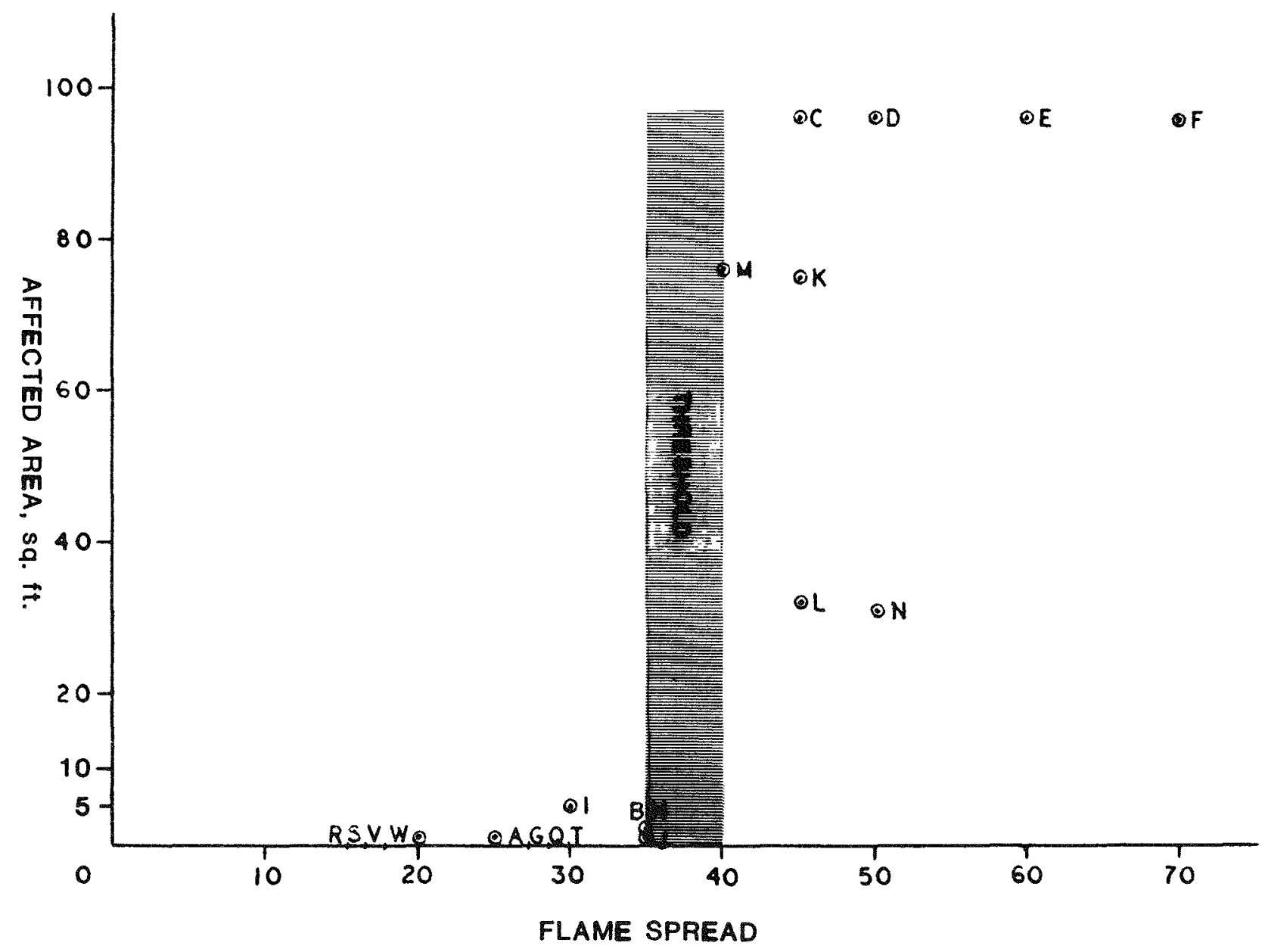

ILL. 9 
RATE OF SMOLDERING COMBUSTION vS.CHEMICAL ADD-ON

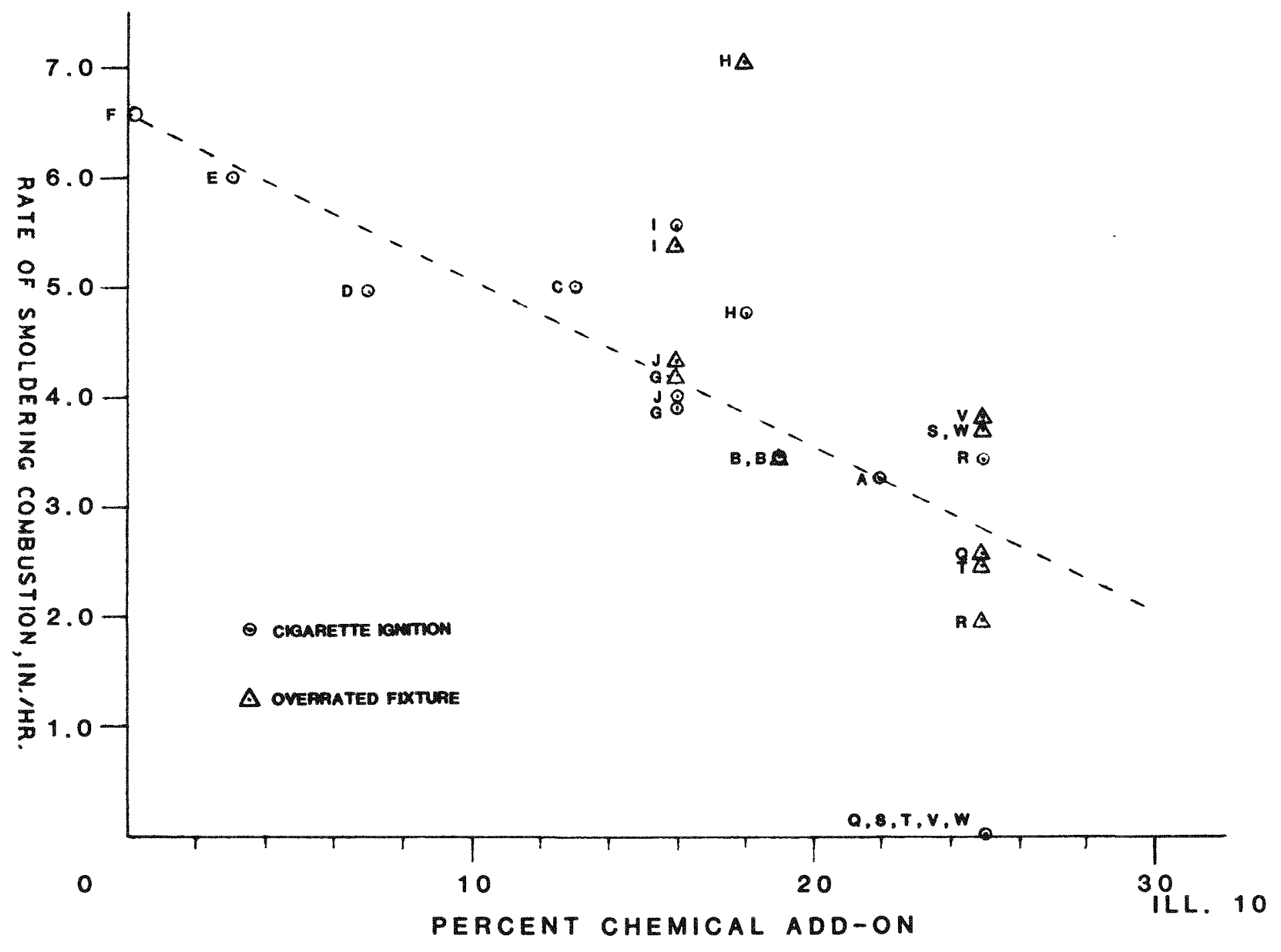


FLAME SPREAD vS. RATE OF SMOLDERING COMBUSTION

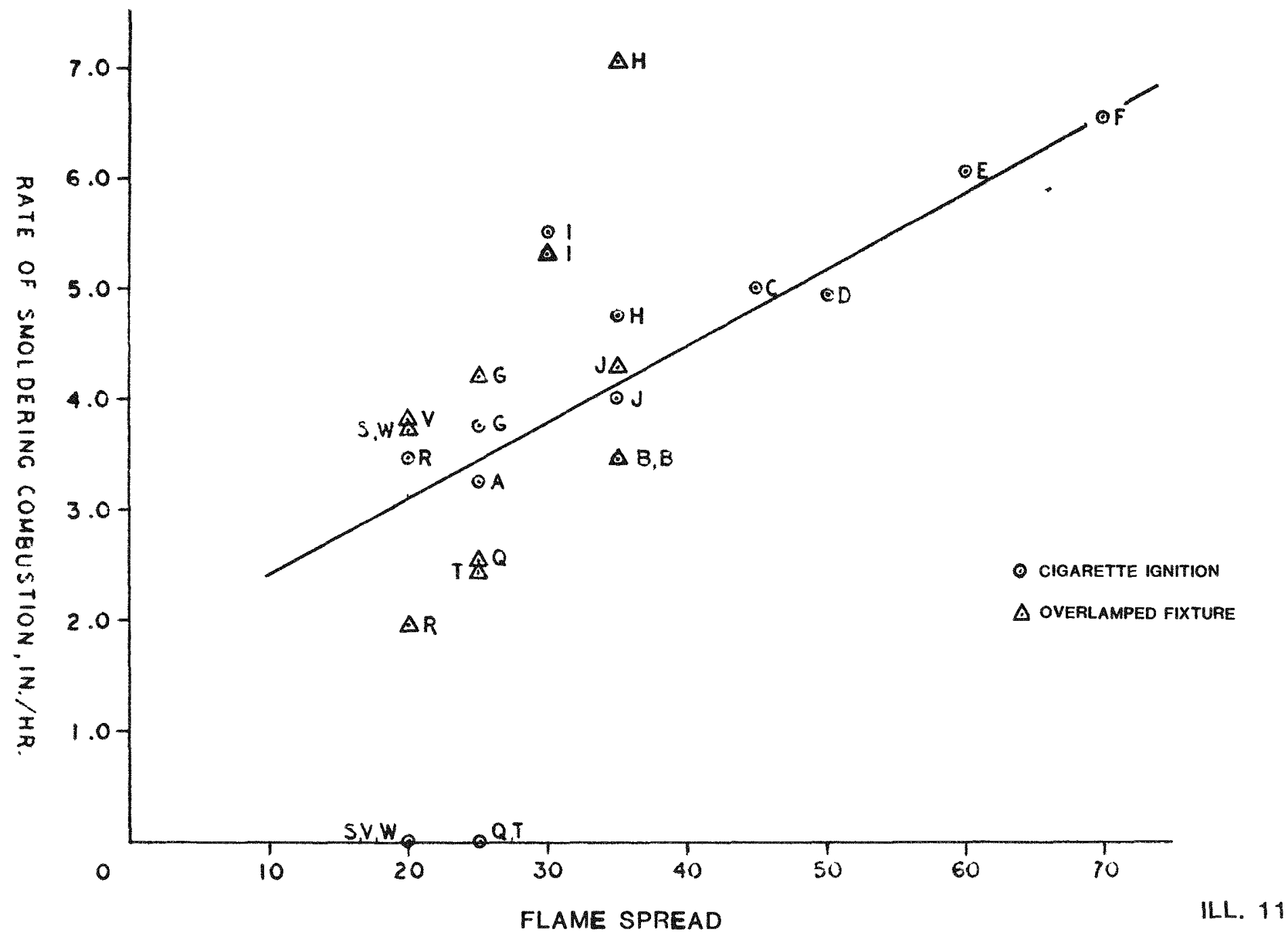




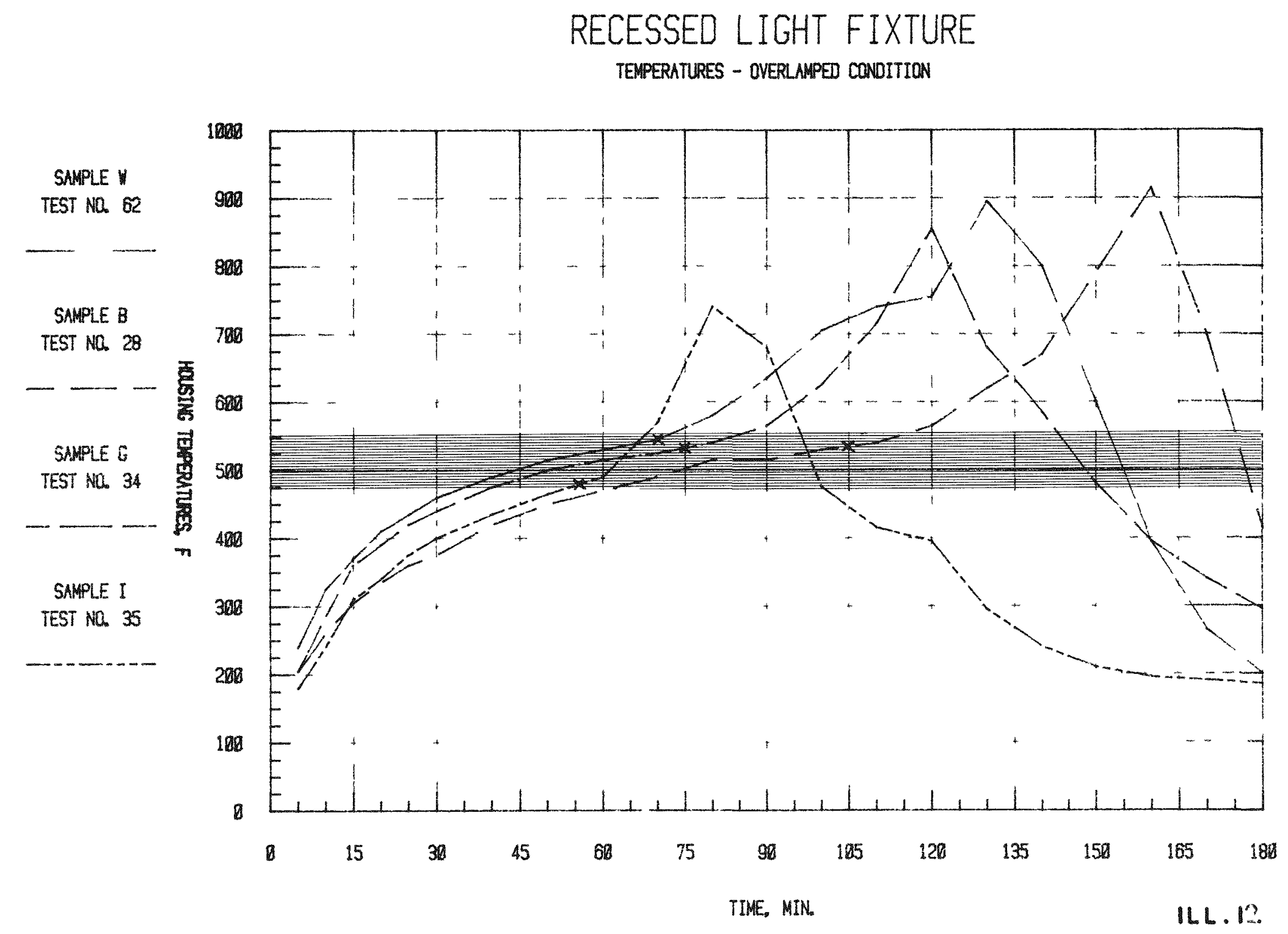


Page 42

File USNC97

\section{APPENDIX A}

\section{TRANSCRIBED VOICE RECORDS}

The following transcribed voice records provides information of time and events occurring during the course of each full-scale simulated attic experiment. 
File USNC97

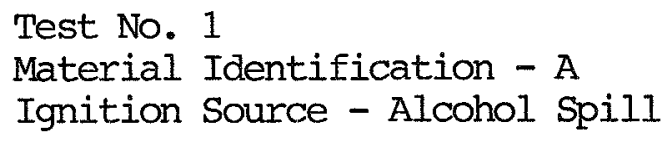

8:40 All flaming and glow self-extinguished. 
File USNC97

Test No. 3

Material Identification - C

Ignition Source - Alcohol Spill

Time, Min

$0: 00$

$0: 10$

$0: 25$

$0: 35$

$0: 54$

$1: 11$

$1: 25$

$1: 47$

$2: 30$

$3: 30$

$4: 10$

$4: 40$

$5: 20$

$6: 25$

$7: 10$

$7: 25$

$7: 45$

$9: 41$
Observations

\section{Ignition.}

Flames spread to 18 in. diameter.

Flames spread to $2 \mathrm{ft}$ mark (cavity 4).

Flames jumped to cavity 5.

Flames spread to 3-1/2 ft mark.

Flames jumped to cavity 3.

Flames spread in two cavities to $5 \mathrm{ft}$.

Flames now in cavities 3, 4, 5 and 6 .

Flames spread in cavities 3 and 4 to $7 \mathrm{ft}$, cavities 5 and 6 to $6-1 / 2 \mathrm{ft}$.

Flames spread in cavities 3 and 4 to $8 \mathrm{ft}$.

Flames spread in cavities 5 and 6 to $8 \mathrm{ft}$.

Flames spread in cavities 3 and 4 to $10 \mathrm{ft}$.

Flames spread in cavity 2 at $8 \mathrm{ft.}$

Flames spread in cavity 4 (spill cavity) to end.

Flaming to end in cavities 5 and 6 .

Flaming out in cavities 4,5 and 6 .

Flames spread to $10-1 / 2 \mathrm{ft}$ in cavity 3 .

Flames spread in cavity 2 to end. 
File USNC97

Time, Min

$10: 16$

$15: 00$

$19: 45$

$25: 00$

$42: 00$

$\star$
Observations

Al1 flaming out. Slight glow in spill area. No sign of glow, appears out. Material continues to smoke in spill area. Smoldering apparent.

Char area to $14 \mathrm{in.} \mathrm{mark.}$

Material continued to smolder. The test was terminated $6 \mathrm{~h}$ after ignition. Refer to smoldering rate column of appropriate tables.

Test No. 4

Material Identification - D

Ignition Source - Alcohol Spill

Time, Min

$0: 00$

$0: 10$

$0: 15$

$0: 30$

$0: 55$

$1: 20$

$1: 50$

$3: 15$

$4: 12$
Observations

Ignition.

Flaming in cavity 4 to $2 \mathrm{ft}$.

Flames jumped to cavities 3 and 5 .

Flames spread to $4 \mathrm{ft}$ in cavities $3,4,5$ and 6.

Flames jumped to cavity 1, spread in all other cavities to $6 \mathrm{ft}$.

Flames spread to $8 \mathrm{ft}$ in all but cavity 1 .

Flames spread to $10 \mathrm{ft}$ in all cavities.

Flames spread to end in all cavities.

All flaming out except in spill area. 
File USNC97

Time, Min

$6: 00$

$11: 25$

$17: 00$

*
Observations

No change.

All flaming out. Slight glow in spill area.

Smoke continues in spill area. Smoldering apparent.

Material continued to smolder. Test terminated 1:45:00 after ignition.

Test No. 5

Material Identification - E

Ignition Source - Alcohol Spill

Time, Min

$0: 00$

$0: 10$

$0: 20$

$0: 25$

$0: 30$

$0: 35$

$1: 00$

$2: 00$

$2: 50$

$3: 10$

$3: 20$

\section{Observations}

Ignition.

Flames spread to 2 ft mark - cavity 4.

Flames jumped to cavities 3 and 5 .

Flames in all but cavity 1.

Flames spread in all affected cavities to $4 \mathrm{ft}$.

Flames spread in all cavities to $5-1 / 2 \mathrm{ft}$.

Flames spread in all cavities to $7 \mathrm{ft}$.

Flames spread to $11 \mathrm{ft}$.

Flames to end in cavities 1, 2, 3 and 6 .

Roof rafters at end of cavity 4 on fire.

Flames to end in cavities 4 and 5. 
File USNC97

Time, Min

Observations

4:30 Flaming out with exception of spill area.

$6: 00 \quad$ No change.

9:45 All flaming out.

15:30 Smoke continues from spill area. Smoldering apparent

* Material continued to smolder. Test terminated 1:30:00 after ignition. Refer to smoldering rate table.

Test No. 6

Material Identification - F

Ignition Source - Alcohol Spill

Time, Min

Observations

$0: 00$

Ignition.

$0: 16$

Flames spread to $2-1 / 2 \mathrm{ft}$ in cavity 4.

$0: 44$

Flames spread to $5 \mathrm{ft}$, all cavities involved.

$1: 04$

Flames spread to $7-1 / 2$ ft in all cavities but No. 6 .

$1: 34$

Flames spread to $9 \mathrm{ft}$ mark.

$1: 46$

Flames to $10 \mathrm{ft}$ in all cavities but No. 6 .

$1: 52$

Flames spread to $10-1 / 2 \mathrm{ft}$.

$1: 58$

Flames to $11 \mathrm{ft}$ in cavities.

$2: 32$

Flames spread to $12 \mathrm{ft}$ in cavities 1,2 and 3.

$4: 05$

Flames spreading in cavity 1 from approx $6 \mathrm{ft}$ mark backwards towards the 0 ft mark. 
File USNC97

Time, Min

$6: 25$

$9: 53$

$20: 00$

$48: 00$

$63: 00$
Observations

All flaming out except in spill area.

Flaming out. Smoke continues.

No change.

Smoke continues and increasing.

Test terminated. Smoldering in cavity 1 at 12 ft mark.

Test No. 7

Material Identification - A

Ignition Source - Cigarette

Time, Min

$0: 00$

$3: 00$

$6: 00$

$13: 00$

$21: 00$

$26: 00$

$33: 00$

$38: 00$

$47: 00$

$53: 00$
Observations

An ignited cigarette has been placed lit end up into the material.

Cigarette continues to smoke; light char surrounding the cigarette.

Discoloration around the source approx $1 / 2$ in. radius.

No change; still smoking.

Smoking increased.

Char approx 1-1/2 in. radius.

Diameter of char 4 in.

Diameter of char 4-1/2 in.

Diameter of char 6 in.

Diameter of char $7 \mathrm{in.}$ 
File USNC97

Time, Min

$62: 00$

$180: 00$

$200: 00$

$214: 00$
Observations

Diameter of char 8 in.

The char reached the 20 in. mark within the cavity. The diameter of char could not continue because as the material charred, it sank into the cavity, therefore, bringing it within a given cavity only.

The char reached the $24 \mathrm{in.} \mathrm{mark.} \mathrm{The} \mathrm{test}$ was terminated.

Refer to the smoldering rate table for the smoldering rate.

Test No. 8

Material Identification - B

Ignition Source - Cigarette

Time, Min

Observations

$0: 00$

The lighted cigarette was placed into the material with the burning end up.

3:00 The cigarette continued to smoke with light char occurring around the cigarette.

6:00 Discoloration around source approx $1 / 2$ in. radius.

13:00 No change; still smoking.

21:00 The sample appears to be out; no flaming or smoke is visible.

26:00 No change.

38:00 The diameter of char is approx 3 in.

47:00 The diameter of char is $4 \mathrm{in}$. 


\section{Page 50}

File USNC97

Time, Min

$53: 00$

$62: 00$

$74: 00$

$84: 00$

$95: 00$

$110: 00$

$131: 00$

$180: 00$

$200: 00$

$214: 00$
Observations

The diameter of char is 5 in.

The diameter of char is 6 in.

The diameter of char is 7 in.

The diameter of char is $10 \mathrm{in}$.

The diameter of char is 6 in.

The diameter of char is 14 in.

The diameter of char is $16 \mathrm{in}$.

The char has reached the 20 in. mark.

The char has reached the 22 in. mark.

The test was terminated. Refer to the smoldering rate table for the individual values.

Test No. 9

Material Identification - C

Ignition Source - Cigarette

Time, Min

Observations

$0: 00$

$2: 00$

$6: 00$

$10: 00$

$15: 00$
Glowing cigarette inserted with glowing end up into material.

1/4 in. radius char around cigarette. 1/2 in. radius char around cigarette. Medium smoke beginning in chamber.

1 in. radius char; smoke increasing to heavy. 1-1/2 in. radius char around cigarette. 
File USNC97

Time, Min Observations

$20: 00$

2 in. radius of char.

$30: 00$

6 in. diameter of char.

$40: 00$

8 in. diameter of char.

$55: 00$

12 in. diameter of char.

$65: 00$

14 in. diameter of char.

$95: 00$

Char has reached the 21 in. mark.

$110: 00$

Char has reached the 22 in. mark.

$135: 00$

Char the full width of the cavity; has extended to the $2 \mathrm{ft}$ mark.

$190: 00$

The test was terminated; char had extended to the $2 \mathrm{ft}, 3 \mathrm{in}$. mark. Refer to the smoldering rate table for individual smoldering rates.

Test No. 10

Material Identification - D

Ignition Source - Cigarette

Time, Min

$0: 00$

$2: 00$

$6: 00$

$10: 00$

$15: 00$
Observations

Glowing cigarette inserted into insulation material.

1/4 in. radius char around cigarette.

1/2 in. radius char around cigarette. Medium smoke in chamber.

No change.

1 in. radius char around cigarette. 
File USNC97

Time, Min Observations

$20: 00$

3 in. diameter char.

$30: 00$

5 in. diameter char.

$40: 00$

8 in. diameter char.

$55: 00$

12 in. diameter char.

$65: 00$

No change.

$95: 00$

16 in. diameter of char. Heavy smoke being emitted from the smoldering area.

110:00 Char has reached the 21 in. mark.

135:00 Char the full width of the cavity and extending to the 2 ft mark.

190:00 The test was terminated; char had extended the full width of the cavity to the $2 \mathrm{ft}$, 9 in. mark. Refer to the smoldering rate table for individual values.

Test No. 11

Material Identification - E

Ignition Source - Cigarette

Time, Min

Observations

$0: 00$

Glowing cigarette installed into insulation material.

4:00 $\quad 1 / 2$ in. radius char around cigarette.

14:00 3 in. diameter char.

30:00 6 in. diameter char. Heavy smoke visible.

45:00 12 in. diameter char. Heavy smoke continues. 
File USNC97

Time, Min

Observations

$60: 00$

14 in. diameter char with heavy smoking.

$70: 00$

Visibility in the attic is limited to three cavities.

$75: 00$

Char is the full width of the cavity and spreads to the 19 in. mark.

$105: 00$

Char has spread to the 21 in. mark.

$120: 00$

Char has spread to the $2 \mathrm{ft}$ mark.

$160: 00$

Char has spread to the $2 \mathrm{ft}, 2$ in. mark.

$200: 00$

Char has spread to $30 \mathrm{in.}$

*

The test was terminated at $7 \mathrm{~h}, 15 \mathrm{~min}$ after ignition. Smoldering continued all during this time. The test, when terminated, had spread to the $4 \mathrm{ft}, 7$ in. mark. Refer to the smoldering rate table for individual values.

Test No. 12

Material Identification - F

Ignition Source - Cigarette

Time, Min

$0: 00$

$4: 00$

$14: 00$

$30: 00$

$45: 00$
Observations

Glowing cigarette inserted into insulation material.

$1 / 2$ in. radius of char; light smoke beginning.

1 in. radius of char; heavy smoking beginning.

4 "in. diameter; heavy smoke continues.

10 in. diameter of char around cigarette. 
File USNC97

Time, Min

$60: 00$

$70: 00$

$75: 00$

$105: 00$

$120: 00$

$160: 00$

$200: 00$

$715: 00$
Observations

12 in. diameter of char around cigarette. Visibility in attic limited to 3 cavities. Char is extended to the full width of the cavity and has spread to 19 in. mark.

Char has spread to the 22 in. mark. Char has reached the 2 ft mark.

Char to the 22 in. mark.

Char has reached the $2-1 / 2$ ft mark.

Test terminated. Smoldering continued up until this point. Spread of char reached a maximum of $4 \mathrm{ft}, 7$ in. Material would have continued to smolder if it were allowed. Refer to the smoldering rate table for individual values.

Test No. 13

Material Identification - B

Ignition Source - Alcohol Spill with Radiant Heating Preheat

Time, Min

$0: 00$

$0: 30$

$1: 30$

$3: 30$

$6: 00$

$7: 30$

$10: 00$
Observations

Ignition of alcohol.

6 in. diameter of char.

No change.

Flame height reduced from 6 in. to 2 in. 6 in. diameter of char.

6 in. diameter of char, $1 / 2$ in. flame height.

Flaming out, minor glow continues.

No smoke, no glow, test terminated. 
File USNC97

Test No. 14

Material Identification - C

Ignition Source - Alcohol Spill with Radiant Heating Preheat

Time, Min Observations

$0: 00$

Ignition.

$0: 30$

Flaming in cavity No. 4 , out to $3 \mathrm{ft}$ mark, flaming has also jumped to cavities 5 and 3.

$1: 10$

Flaming to $4 \mathrm{ft}$ mark in cavity $4,3-1 / 2 \mathrm{ft}$ in cavities 3,5 and 6 .

$2: 00$

Flaming to 5 ft in cavities 3, 4, 5 and 6 .

$2: 30$

Flaming in all cavities to 5-1/2 $\mathrm{ft}$.

$3: 30$

Flaming subsiding in all cavities.

$4: 45$

All flaming out except in spill area.

$8: 30$

Light flickering at alcohol spill only.

$11: 45$

All flaming is out, no apparent smoldering. Test terminated.

Test No. 15

Material Identification - B

Ignition Source - Propane Torch

Time, Min

Observations

$0: 00$

Ignition of torch.

$0: 13$

Ignition of sample material as the burner is lowered at approx the $60 \mathrm{deg}$ angle to within 1 in. of the surface.

$0: 50$

6 in. diameter of char. 
File USNC97

Time, Min

$1: 42$

$3: 00$

$5: 00$

$10: 00$
Observations

Light smoke from ignition area. Flames have spread to approx 19 in.

No change. All flaming of sample appears out; only the test flame continues.

No change.

Flame removed and test terminated.

Sample continues to smolder at point of flame contact.

Test No. 16

Material Identification - C

Ignition Source - Propane Torch

Time, Min

Observations

$0: 00$

$0: 15$

$0: 40$

Ignition of material on contact in cavity form.

Spread in cavity form to 2-1/2 ft, flames have jumped to cavities 3 and 5.

Flames jumped to cavities 2 and 6 , spread to $5 \mathrm{ft}$.

2:00 Spread to $6 \mathrm{ft}$ in cavities 4 and 6 , spread to $5 \mathrm{ft}$ in cavities 2 and 3.

4:00 Spread of flame to $8 \mathrm{ft}$ in cavity 6, all other flaming appears out.

6:00 Flaming appears out.

10:00 Test terminated; light smoke in ignition area indicates presence of smoldering. 
File USNC97

Test No. 17

Material Identification - 0

Ignition Source - Alcohol Spill

\begin{tabular}{|c|c|}
\hline Time, Min & Observations \\
\hline $0: 00$ & Ignition of alcohol. \\
\hline $1: 00$ & $\begin{array}{l}\text { Discoloration of the sample material in the } \\
\text { direct spill area. }\end{array}$ \\
\hline $2: 00$ & $\begin{array}{l}\text { Light flaming in the glass below the surface; } \\
\text { slight smoking observed. }\end{array}$ \\
\hline $3: 00$ & No change. \\
\hline $4: 00$ & $\begin{array}{l}\text { Flaming within the material appears to be } \\
\text { out. }\end{array}$ \\
\hline $5: 00$ & No activity can be seen. \\
\hline $10: 00$ & Test terminated. \\
\hline \multicolumn{2}{|c|}{$\begin{array}{l}\text { Test No. } 18 \\
\text { Material Identification - P } \\
\text { Ignition Source - Alcohol Spill }\end{array}$} \\
\hline Time, Min & Observations \\
\hline $0: 00$ & Ignition of alcohol. \\
\hline $1: 00$ & $\begin{array}{l}\text { No change other than the flaming that remains } \\
\text { in the ignition area. }\end{array}$ \\
\hline $2: 00$ & $\begin{array}{l}\text { Flames approx } 4 \text { to } 6 \text { in. high. No change or } \\
\text { char noticed in material. }\end{array}$ \\
\hline $3: 00$ & No change. \\
\hline
\end{tabular}


File USNC97

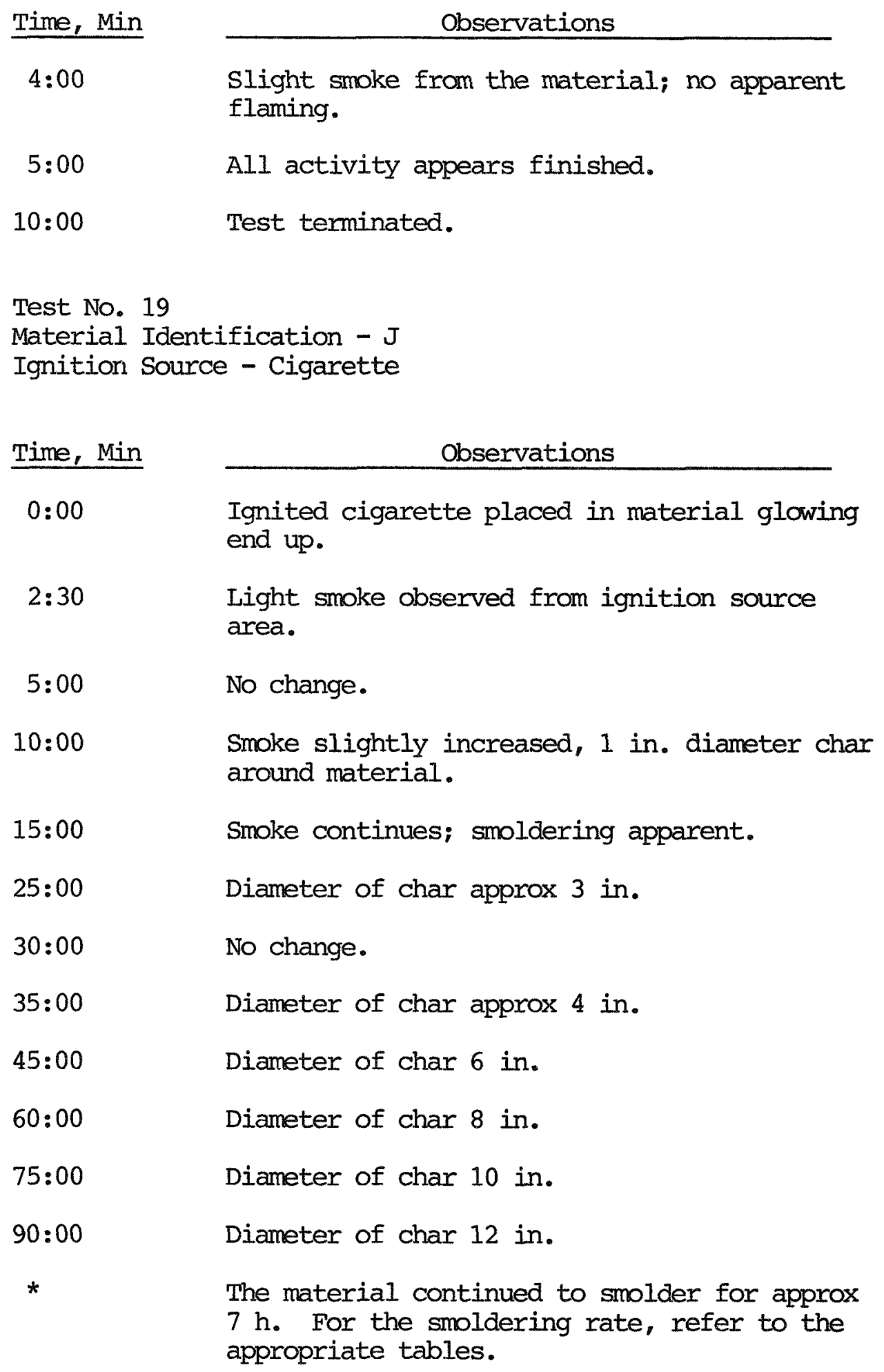
appropriate tables. 
File USNC97

Test No. 20

Material Identification - I

Ignition Source - Cigarette

Time, Min

Observations

$0: 00$

Ignited cigarette placed in material glowing end up.

Light smoke detected from ignition area.

$5: 00$

No change.

$10: 00$

Smoking slightly increased, 1 in. diameter char around cigarette.

$15: 00$

Smoke continues, smoldering apparent.

$25: 00$

Smoking continues, diameter of char around cigarette 3 in.

$30: 00$

No change.

$35: 00$

Diameter of char approx 3 in.

$45: 00$

Diameter of char around cigarette 5 in.

$60: 00$

Diameter of char 7 in.

$75: 00$

Diameter of char 9 in.

$90: 00$

Diameter of char approx 14 in. time the test was terminated. Refer to the smoldering table for the appropriate rate. 
File USNC97

Test No. 21

Material Identification - $\mathrm{H}$

Ignition Source - Cigarette

Time, Min

$0: 00$

$5: 00$

$10: 00$

$20: 00$

$45: 00$

$60: 00$

$75: 00$

*
Observations

Ignited cigarette placed in material glowing end up.

No apparent activity.

$1 / 2$ in. radius of char from around cigarette.

3 in. diameter char; smoke increasing.

6 in. diameter of char around cigarette. smoke continues to increase.

10 in. diameter char.

12 in. diameter of char.

Material continued to smolder approx $7 \mathrm{~h}$ at which time the test was terminated. For the calculated smoldering rate, see the appropriate tables.

Test No. 22

Material Identification - B

Ignition Source - Light Fixture Rated Bulb

At 9:30 in the morning, after $2 \mathrm{~h}$ of preheat, the recessed light fixture was switched on. Temperatures were monitored during the test with no smoke, no discoloration of the material and no smoldering apparent when the test was terminated at 9:00 P.M. 
File USNC97

Test No. 23

Material Identification - $\mathrm{H}$

Ignition Source - Light Fixture Rated Bulb

At 9:30 in the morning, after $2 \mathrm{~h}$ of preheat, the recessed light fixture was switched on. Temperatures were monitored during the test with no smoke, no discoloration of the material and no smoldering apparent when the test was terminated at 9:00 P.M.

Test No. 24

Material Identification - $\mathrm{H}$

Ignition Source - Alcohol Spill

Time, Min Observations

$0: 00$ Ignition.

$0: 30$

4 in. diameter char.

$1: 00$

5 in. diameter of char.

$3: 00$

No change.

$4: 00$

Flame diminishing.

$6: 00$

Light flaming approx 1 in. high; no further spread.

$8: 30$

Light smoke increasing.

$10: 00$

Light flaming and smoke continues; smoke increasing.

$15: 00$

Flaming out, smoke continues, smoldering apparent. 
File USNC97

Test No. 25

Material Identification - I

Ignition Source - Alcohol Spill

Time, Min

Observations

$0: 00$

$0: 30$

$1: 15$

$2: 15$

$5: 00$

$9: 00$

$10: 00$
Ignition.

Flames spread to 2 ft mark, full cavity width, flames have jumped to cavity 5.

Flame spread remains at $2 \mathrm{ft}$. Smoke only observed in cavity 5.

Flame front out. Flaming only observed in the ignition area.

Light flaming in the source area only. Light smoke continues.

No change.

Flaming out. Smoke increasing, smoldering evident.

Test No. 26

Material Identification - J

Ignition Source - Alcohol Spill

Time, Min

Observations

$0: 00 \quad$ Ignition.

$0: 30 \quad 4$ in. diameter char, flame height extending

6 in.

$2: 30 \quad$ No change.

6:30 Light flaming and smoke continues. 
File USNC97

Time, Min

Observations

8:00 Decreased flaming.

10:00 Flaming out, light smoke continues.

15:00 No smoke observed. Test terminated. No apparent smoldering.

Test No. 27

Material Identification - $\mathrm{H}$

Ignition Source - Light Fixture over Iamped

The attic was preheated for $2 \mathrm{~h}$ prior to switching on the recessed light fixture. Preheat was continued for an additional $2 \mathrm{~h}$. Smoldering took place within $2 \mathrm{~h}$ after the light fixture was turned on and continued during the remaining 5 or $6 \mathrm{~h}$ of the test. See the appropriate tables for the smoldering rate.

Test No. 28

Material Identification - B

Ignition Source - Light Fixture Over Lamped

The attic chamber was preheated for $2 \mathrm{~h}$ prior to actuation of the recessed light fixture. The preheat continued for two additional hours. Within the continuing preheat period, smoldering was evident and continued during the remaining $6 \mathrm{~h}$ of the test. For the appropriate smoldering rates, see the smoldering rate table.

Test No. 29

Material Identification - G

Ignition Source - Alcohol Spill

Time, Min

Observations

$0: 00 \quad$ Ignition.

0:30 Flame spread to $6 \mathrm{in}$. diameter, flames 4 to 6 in. high. 


\section{Page 64}

File USNC97

Time, Min

$2: 00$

$4: 30$

$7: 00$

$9: 00$

$13: 00$
Observations

Flame front back to ignition source.

Light flaming only observed in the ignition source area. Light smoke also observed.

Light surface flaming in the material. Very light smoke.

Flaming out. Light smoke continues.

No smoking or flame is evident. Test terminated.

Test No. 30

Material Identification - $\mathrm{N}$

Ignition Source - Alcohol Spill

Time, Min

$0: 00$

$0: 05$

$0: 10$

$0: 45$

$1: 00$

$1: 30$

$2: 30$

$3: 15$

$4: 30$
Observations

Ignition.

Flame spread to $12 \mathrm{in.} \mathrm{radius.}$

Flames jumped into cavities 3 and 5.

Flames spread to the 3 ft mark.

Flames jumped into cavities 6 and 2 .

Spread to $4 \mathrm{ft}$ mark.

Flames have spread into cavity 1.

Flames spread to the $5 \mathrm{ft}$ mark in cavity 5 , 3 ft mark in cavity 2 .

Flaming out in cavity 5. Flaming continues in cavity 2 . 
File USNC97

Time, Min

$5: 13$

$12: 00$

$17: 00$
Observations

Flaming out in cavity 2. Only flaming at ignition source. Light flaming in ignition area at $7 \mathrm{~min}$. Light smoke from the source.

Smoke increasing in the ignition area.

Test terminated. Smoldering evident.

Test No. 31

Material Identification - G

Ignition Source - Light Fixture Rated Bulb

The attic chamber was preheated for $2 \mathrm{~h}$ prior to actuation of the recessed light fixture. The preheat continued for an additional $2 \mathrm{~h}$, after which it was turned off. The lamp remained on. The lamp remained on through the entire test. The results of the test indicated no smoking, no charring or discoloration of the insulation around the lamp and no smoldering.

Test No. 32

Material Identification - I

Ignition Source - Light Fixture Rated Bulb

The attic chamber was preheated for $2 \mathrm{~h}$ prior to actuation of the recessed light fixture. Preheating continued for an additional $2 \mathrm{~h}$, at which time it was terminated and the light remained on during the entire test. The results of the test indicated no smoke, no charring or discoloration of the material adjacent to the light fixture and no smoldering after a period of approx $6 \mathrm{~h}$ of exposure. 
File USNC97

Test No. 33

Material Identification - L

Ignition Source - Alcohol Spill

Time, Min

Observations

$$
0: 00
$$

$0: 30$

$1: 00$

$2: 00$

$3: 00$

$3: 30$

$4: 00$

$5: 00$

$8: 00$

$9: 00$

$10: 00$

$13: 00$
Ignition.

Flames spread to 8 in. of ignition source, full width of the cavity, flames jumping to cavities 3 and 5 .

16 in. spread in all directions.

Flames spread to cavity 1, spread to the $4 \mathrm{ft}$ mark in cavity 4 , slightly less in cavities 3 and 5 .

Flames jumped to cavity 2 .

Flames spread now to the $5 \mathrm{ft}$ mark.

Flaming continues in all cavities.

Flaming to $6-1 / 2$ ft in cavities 2,3 and 4 . Flaming to $7 \mathrm{ft}$ in cavity 4 at $6 \mathrm{~min}$.

All flaming out except in cavity 1 , moving backward toward the perpendicular plane of the ignition source.

Ignition source flaming out.

All flaming out. Smoke continues.

Smoldering evident. Test terminated. 
File USNC97

Test No. 34

Material Identification - G

Ignition Source - Iight Fixture Over Iamped

The attic chamber was preheated for $2 \mathrm{~h}$ prior to actuation of the recessed light fixture. The preheat continued for an additional $2 \mathrm{~h}$ at which time the preheat was terminated. The lamp remained on throughout the entire test from that point on. Smoldering occurred within the first $2 \mathrm{~h}$ after the lamp was ignited and continued throughout the remainder of the test which was approx $6 \mathrm{~h}$. For the smoldering rate, see the appropriate tables.

Test No. 35

Material Identification - I

Ignition Source - Light Fixture Over Iamped

The attic chamber was preheated for $2 \mathrm{~h}$ prior to the actuation of the recessed light fixture. The preheat continued for an additional $2 \mathrm{~h}$ at which time it was terminated. The light continued on from ignition until the end of the test. Within the first $2 \mathrm{~h}$ after ignition of the lamp, smoldering occurred and continued throughout the remaining $6 \mathrm{~h}$ of the test. For the smoldering rate, see the appropriate tables.

Test No. 36

Material Identification - $\mathrm{K}$

Ignition Source - Alcohol Spill

Time, Min

Observations

$0: 00 \quad$ Ignition.

1:00 Flaming has spread into cavities 5, 6, 3 and 2 and has spread to $3 \mathrm{ft}$.

1:20 The flames have spread to $4 \mathrm{ft}$ in cavities 3 , 4 and 5 . 
File USNC97

Time, Min

$2: 00$

$2: 30$

$3: 30$

$5: 00$

$6: 00$

$7: 15$

$7: 40$

$10: 00$

$20: 00$

$25: 00$

$38: 00$

$40: 00$
Observations

Flaming has spread into cavity 1.

Flames spread to $6-1 / 2 \mathrm{ft}$ in all affected cavities.

Flames spread to $8 \mathrm{ft}$ in cavities 2 through 6.

Flames spread to 9 and 10 ft mark in cavities $2,3,4,5$ and 6 .

Flames spread to $11 \mathrm{ft}$ in cavities 4 and 6 to the $10 \mathrm{ft}$ mark in cavity 2 .

Flame front is out in cavities 1,2 and 3. Flames continue in the remaining three cavities.

Flames have reached the 12 ft mark in cavities 4,5 and 6 .

Flaming out in cavities 4 and 6 .

Flaming out in cavity 5. Light flaming at the ignition source.

No change.

Light flaming continues at the ignition source. Smoldering is evident.

Flaming is increasing in the 6 in. diameter circle around the source.

Smoldering continues in cavities 3, 4 and 5. Light spontaneous flaming is observed in cavity 4 for approx a 10 in. char circle.

All flaming out. Test terminated. Smoldering is evident. 
File USNC97

Test No. 37

Material Identification - M

Ignition Source - Alcohol Spill

Time, Min

$0: 00$

$0: 30$

$1: 15$

$2: 00$

$2: 15$

$3: 00$

$3: 45$

$4: 00$

$4: 45$

$5: 30$

$6: 00$

$10: 00$
Observations

Ignition.

Flames spread to cavities 3 and 5. Flame spread to the $3 \mathrm{ft}$ mark.

Flames have jumped to cavities 6 and 2. Flame spread to the $6 \mathrm{ft}$ mark in cavity 4.

Flames have jumped to cavity 1.

Flames to the $8 \mathrm{ft}$ mark and moving rapidly.

Flames to the $11-1 / 2 \mathrm{ft}$ mark in cavities 4 and 5 .

Flames to the $12 \mathrm{ft}$ mark in cavities 4 and 5.

Flaming out in cavities 6 and 1.

Flaming out in cavities 2, 4 and 5. Only cavity 3 continues to flame to the $11 \mathrm{ft}$ mark.

Flaming has extended to the $12 \mathrm{ft}$ mark in cavity 3 and has jumped over to cavity 2 .

The roof rafter ignited and started to flame. It was necessary to extinguish this before continuing the test.

All flaming was out. Smoldering was apparent. The test was terminated at $15 \mathrm{~min}$. 
File USNC97

Test No. 38

Material Identification - G

Ignition Source - Cigarette

Time, Min

Observations

$0: 00$

Ignited cigarette placed with glowing end up.

3:00 Light smoke evident. A browning of the material directly adjacent to the source.

9:00 No change.

20:00 Smoke increasing in the area of the char surrounding the cigarette.

27:00 No change.

35:00 Smoldering evident, smoke increasing.

45:00 3 in. diameter char around cigarette. Smoke increasing.

60:00 4 in. diameter char around source. Smoke continues to increase.

$449: 00$

After the test began, the test was terminated. During that time, smoldering was evident and continued. For the appropriate smoldering rate, see the smoldering tables.

Test No. 39

Material Identification - I

Ignition Source - Insulated Light Fixture Rated Bulb

The attic chamber was preheated for $2 \mathrm{~h}$ prior to actuation of the recessed light fixture. Preheating continued for an additional $2 \mathrm{~h}$, at which time it was terminated and the light remained on during the entire test. The results of the test indicated no smoke, no charring or discoloration of the material adjacent to the light fixture and no smoldering. 


\section{Page 71}

File USNC97

Test No. 40

Material Identification - J

Ignition Source - Light Fixture over Lamped

The attic chamber was preheated $2 \mathrm{~h}$ prior to actuation of the recessed light fixture. The preheat continued for an additional $2 \mathrm{~h}$ and was then terminated. The lamp continued to burn throughout the remainder of the test. Within $2 \mathrm{~h}$ after the ignition of the lamp, smoldering was evident. The smoldering was allowed to continue for approx $6 \mathrm{~h}$ before the test was terminated. For the appropriate smoldering rate, see the smoldering tables.

Test No. 41

Material Identification - J

Ignition Source - Overheated Wire

The attic chamber was preheated for $2 \mathrm{~h}$ prior to activating the overheated wire apparatus. The preheat was continued for two additional hours. Temperatures adjacent to the source were monitored during the test with no smoke, no discoloration or smoldering of the material apparent when the test was terminated. See Table 7 for temperature profile.

Test No. 42

Material Identification - S

Ignition Source - Alcohol Spill

Time, Min

Observations

$0: 00$

Ignition of alcohol.

$0: 15$

Flames extending to $4 \mathrm{in}$. diameter.

$0: 30$

Flames extending to 5 in. diameter; 3 in. flame height.

$1: 00$

Flames decreasing. 
File USNC97

Time, Min

$2: 00$

$7: 45$

$12: 30$
Observations

Iight flickers in spill area only. No change.

Test No. 43

Material Identification - T

Ignition Source - Alcohol Spill

Time, Min

Observations

0:00 Ignition of alcohol.

0:15 Flames extending to 4 in. diameter; 4 in. flame height.

3:30 Flames decreasing.

8:00 Flickering flames in spill area.

10:00 Test terminated.

Test No. 44

Material Identification - T

Ignition Source - Cigarette

Time, Min

Observations

$0: 00$

Glowing cigarette inserted into insulation material.

90:00 1 in. diameter light discoloration around cigarette.

180:00 No smoldering. Test terminated. 
File USNC97

Test No. 45

Material Identification - S

Ignition Source - Cigarette

Time, Min

$0: 00$

$90: 00$

$180: 00$
Observations

Glowing cigarette inserted into insulation material.

1 in. diameter light discoloration around cigarette. No smoldering. Test terminated.

Test No. 46

Material Identification - W

Ignition Source - Alcohol Spill

Time, Min

$0: 00$

$0: 15$

$0: 45$

$2: 00$

$4: 00$

$12: 42$
Observations

Ignition of alcohol.

Flames extending to 4 in. diameter, green-yellow flame approx 3 in. flame height.

Flames extending to 5 in. diameter.

Flames decreasing, 2 in. flame height.

Light flickers in spill area only.

All flame and glow self-extinguished. 
File USNC97

Test No. 47

Material Identification - R

Ignition Source - Alcohol Spill

Time, Min

Observations

0:00 Ignition of alcohol.

0:15 Flames extending to $4 \mathrm{in.}$ diameter, $3 \mathrm{in.}$ flame height.

1:00 No change.

1:45 Flames decreasing, 2 in. height greenish flame.

3:30 Flames in spill area only.

8:30 Light blue flickers in spill area.

14:15 All flame and glow self-extinguished.

Test No. 48

Material Identification - W

Ignition Source - Cigarette

Time, Min

Observations

$0: 00$

Glowing cigarette inserted into insulation material.

10:00 1/2 in. diameter discoloration and light smoke around cigarette.

17:00 1 in. diameter discoloration. Smoldering indicated.

110:00 No smoke, no smoldering, test terminated. 
File USNC97

Test No. 49

Material Identification - $R$

Ignition Source - Cigarette

Time, Min

Observations

$0: 00$

Glowing cigarette inserted into insulation material.

11:00 3/4 in. diameter of discoloration and increasing smoke around cigarette.

$18: 00$ 1-1/2 in. diameter discoloration. Smoldering evident.

73:00 6 in. diameter char.

85:00 8 in. diameter char.

193:00 Char the full width of cavity, extending to $18 \mathrm{in.}$ length and heavy smoke being emitted.

$328: 00$

Char has reached 32 in. mark.

583:00 The test was terminated; char had extended the full width of the cavity to the 47 in. mark. Refer to the smoldering rate table for individual values.

Test No. 50

Material Identification - V

Ignition Source - Alcohol Spill

Time, Min

Observations

$0: 00 \quad$ Ignition of alcohol.

0:15 Flames extending to $6 \mathrm{in}$. diameter and $4 \mathrm{in}$. flame height.

1:00 Flames extending to $8 \mathrm{in}$. width, $6 \mathrm{in.} \mathrm{length}$ with 3 in. high green flame. 
File USNC97

\begin{tabular}{|c|c|}
\hline Time, Min & Observations \\
\hline $2: 00$ & No change. \\
\hline $3: 00$ & Flames decreasing, 1-1/2 in. flame height. \\
\hline $5: 00$ & Light flickers in spill area only. \\
\hline $11: 02$ & Al1 flame and glow self-extinguished. \\
\hline \multicolumn{2}{|c|}{$\begin{array}{l}\text { Test No. } 51 \\
\text { Material Identification - Q } \\
\text { Ignition Source - Alcohol Spill }\end{array}$} \\
\hline Time, Min & Observations \\
\hline $0: 00$ & Ignition of alcohol. \\
\hline $0: 15$ & $\begin{array}{l}\text { Flames extending to } 10 \text { in. width, } 8 \text { in. } \\
\text { length and } 4 \text { in. flame height. }\end{array}$ \\
\hline $1: 00$ & $\begin{array}{l}\text { Flames decreased to spill area, } 3 \text { in. flame } \\
\text { height. }\end{array}$ \\
\hline $3: 00$ & No change. \\
\hline $8: 00$ & Light flickers in spill area only. \\
\hline $10: 02$ & All flame and glow self-extinguished. \\
\hline
\end{tabular}

Test No. 52

Material Identification - V

Ignition Source - Cigarette

\begin{tabular}{ll} 
Time, Min & \multicolumn{1}{c}{ Observations } \\
$0: 00$ & $\begin{array}{l}\text { Glowing cigarette inserted into insulation } \\
\text { material. }\end{array}$ \\
$8: 00$ & $\begin{array}{l}\text { 1/2 in. diameter of discoloration and light } \\
\text { smoke around cigarette. }\end{array}$
\end{tabular}


File USNC97

Time, Min

Observations

$68: 00$

1 in. diameter char, 1-1/2 in. diameter discoloration, no smoke, no glow. Test terminated.

Test No. 53

Material Identification - Q

Ignition Source - Cigarette

Time, Min

$0: 00$

$19: 00$

$79: 00$
Observations

Glowing cigarette inserted into insulation material.

1/2 in. diameter char, 1 in. diameter discoloration and light smoke around cigarette.

1 in. diameter char, 1-1/2 in. diameter discoloration, no smoke, no smoldering. Test terminated.

Test No. 54

Material Identification - $\mathrm{R}$

Ignition Source - Cigarette

Time, Min

Observations

$0: 00$

Glowing cigarette inserted into insulation material.

67:00 5 in. diameter char and medium smoke around cigarette, smoldering evident.

$265: 00$

"Char the full width of cavity and extending to 25 in. mark. Original cigarette burn test verified. Test terminated. 
File USNC97

Test No. 55

Material Identification - V

Ignition Source - Light Fixture Rated Bulb

At 2:00 P.M. after $2 \mathrm{~h}$ of preheat, the light fixture was switched on. Temperatures were monitored during the test with no smoke, no discoloration of the material and no smoldering apparent when the test was terminated at 9:00 P.M. The fixture body temperature was $290^{\circ} \mathrm{F}$.

Test No. 56

Material Identification - S

Ignition Source - Light Fixture Rated Bulb

At 2:00 P.M. after $2 \mathrm{~h}$ of preheat, the light fixture was switched on. Temperatures were monitored during the test with no smoke, no discoloration of the material and no smoldering apparent when the test was terminated at 9:00 P.M. The fixture body temperature was $290^{\circ} \mathrm{F}$.

Test No. 57

Material Identification - Q

Ignition Source - Light Fixture Rated Bulb

At 2:00 P.M. after $2 \mathrm{~h}$ of preheat, the light fixture was switched on. Temperatures were monitored during the test with no smoke, no discoloration of the material and no smoldering apparent when the test was terminated at 9:00 P.M. The fixture body temperature was $315^{\circ} \mathrm{F}$.

Test No. 58

Material Identification - $T$

Ignition Source - Light Fixture Rated Bulb

At 2:00 P.M. after $2 \mathrm{~h}$ of preheat, the light fixture was switched on. Temperatures were monitored during the test with no smoke, no discoloration of the material and no smoldering apparent when the test was terminated at 9:00 P.M. The fixture body temperature was $315^{\circ} \mathrm{F}$. 
File USNC97

Test No. 59

Material Identification - V

Ignition Source - Light Fixture Over Lamped

The attic chamber was preheated for $2 \mathrm{~h}$ prior to actuation of the recessed light fixture. The preheat continued for two additional hours. Within the continuing preheat period, smoldering was evident and continued during the remainder of the test. For the appropriate smoldering rates, see the smoldering rate table. The fixture body temperature prior to smoldering was approx $550^{\circ} \mathrm{F}$.

Test No. 60

Material Identification - S

Ignition Source - Light Fixture Over Lamped

The attic chamber was preheated for $2 \mathrm{~h}$ prior to actuation of the recessed light fixture. The preheat continued for two additional hours. Within the continuing preheat period, smoldering was evident and continued during the remainder of the test. For the appropriate smoldering rates, see the smoldering rate table. The fixture body temperature prior to smoldering was approx $550^{\circ} \mathrm{F}$.

Test No. 61

Material Identification - Q

Ignition Source - Light Fixture Over Lamped

The attic chamber was preheated for $2 \mathrm{~h}$ prior to actuation of the recessed light fixture. The preheat continued for two additional hours. Within the continuing preheat period, smoldering was evident and continued during the remainder of the test. For the appropriate smoldering rates, see the smoldering rate table. The fixture body temperature prior to smoldering was approx $550^{\circ} \mathrm{F}$. 
File USNC97

Test No. 62

Material Identification - T

Ignition Source - Light Fixture Over Lamped

The attic chamber was preheated for $2 \mathrm{~h}$ prior to actuation of the recessed light fixture. The preheat continued for two additional hours. Within the continuing preheat period, smoldering was evident and continued during the remainder of the test. For the appropriate smoldering rates, see the smoldering rate table. The fixture body temperature prior to smoldering was approx $550^{\circ} \mathrm{F}$.

Test No. 63

Material Identification - $W$

Ignition Source - Light Fixture Over Lamped

The attic chamber was preheated for $2 \mathrm{~h}$ prior to actuation of the recessed light fixture. The preheat continued for two additional hours. Within the continuing preheat period, smoldering was evident and continued during the remainder of the test. For the appropriate smoldering rates, see the smoldering rate table. The fixture body temperature prior to smoldering was approx $550^{\circ} \mathrm{F}$.

Test No. 64

Material Identification - $W$

Ignition Source - Light Fixture Rated Bulb

At 12:00 P.M. after $2 \mathrm{~h}$ of preheat, the light fixture was switched on. Temperatures were monitored during the test with no smoke, no discoloration of the material and no smoldering apparent when the test was terminated at 5:30 P.M. The maximum fixture body temperature was $320 \mathrm{~F}$. 
File USNC97

Test No. 65

Material Identification - R

Ignition Source - Light Fixture Over Lamped

The attic chamber was preheated for $2 \mathrm{~h}$ prior to actuation of the recessed light fixture. The preheat continued for two additional hours. Within the continuing preheat period, smoldering was evident and continued during the remainder of the test. For the appropriate smoldering rates, see the smoldering rate table. The fixture body temperature prior to smoldering was approx $550^{\circ} \mathrm{F}$.

Test No. 66

Material Identification - $\mathrm{R}$

Ignition Source - Light Fixture Rated Bulb

At 12:00 P.M. after $2 \mathrm{~h}$ of preheat, the light fixture was switched on. Temperatures were monitored during the test with no smoke, no discoloration of the material and no smoldering apparent when the test was terminated at 5:40 P.M. The maximum fixture body temperature was $300 \mathrm{~F}$. 


\title{
Page 82
}

File USNC97

\author{
APPENDIX B \\ PHOTOGRAPHIC DOCUMENTATION
}

The following photographic documentation provides information of selected fire tests under exposure to the $25 \mathrm{ft}$ Tunnel Test, Attic Floor Radiant Panel Test, and Ful1-Scale Simulated Attic Tests.

NOTE: The reproduction of the photographs are poorer because color photographs were submitted by the subcontractor. 


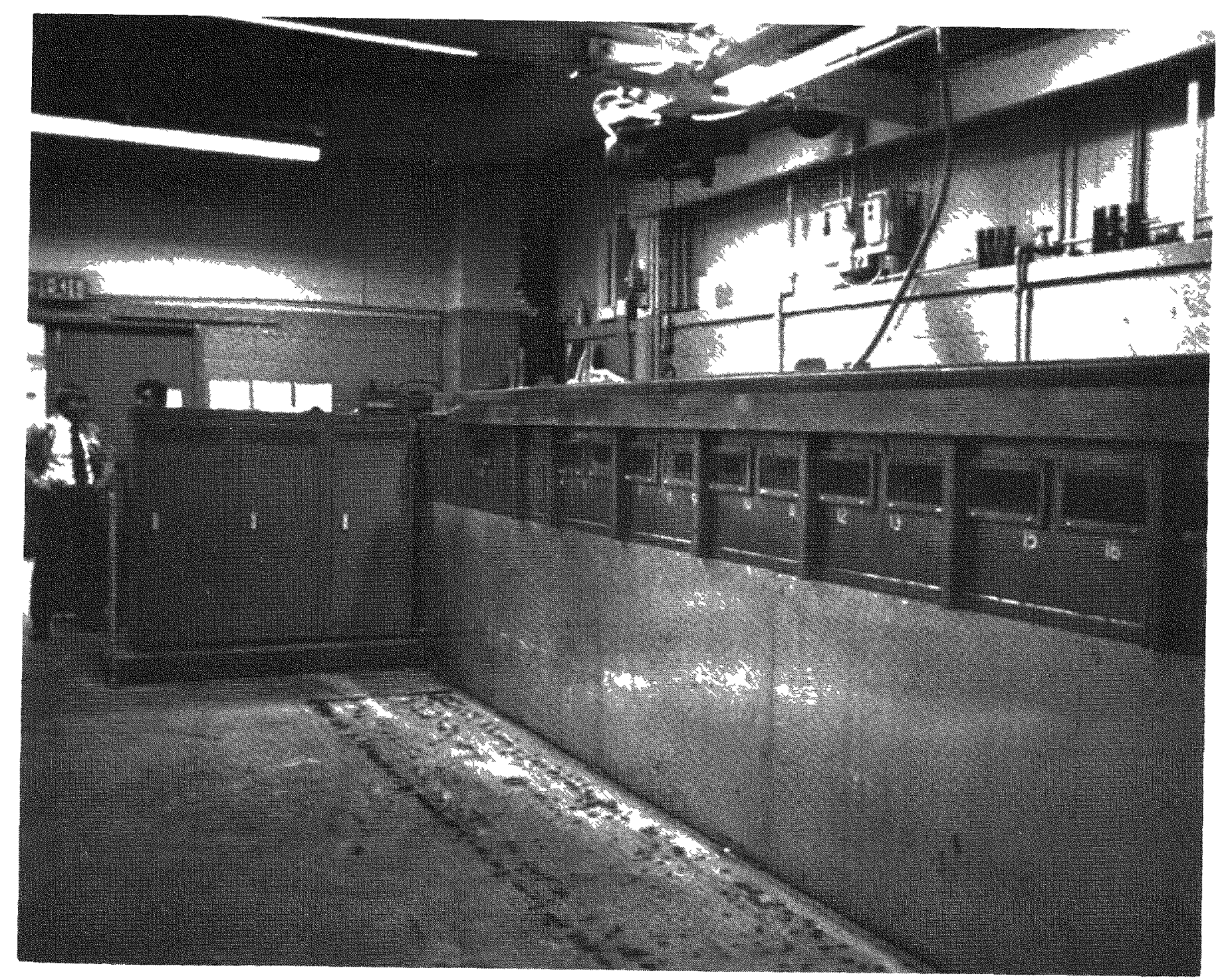




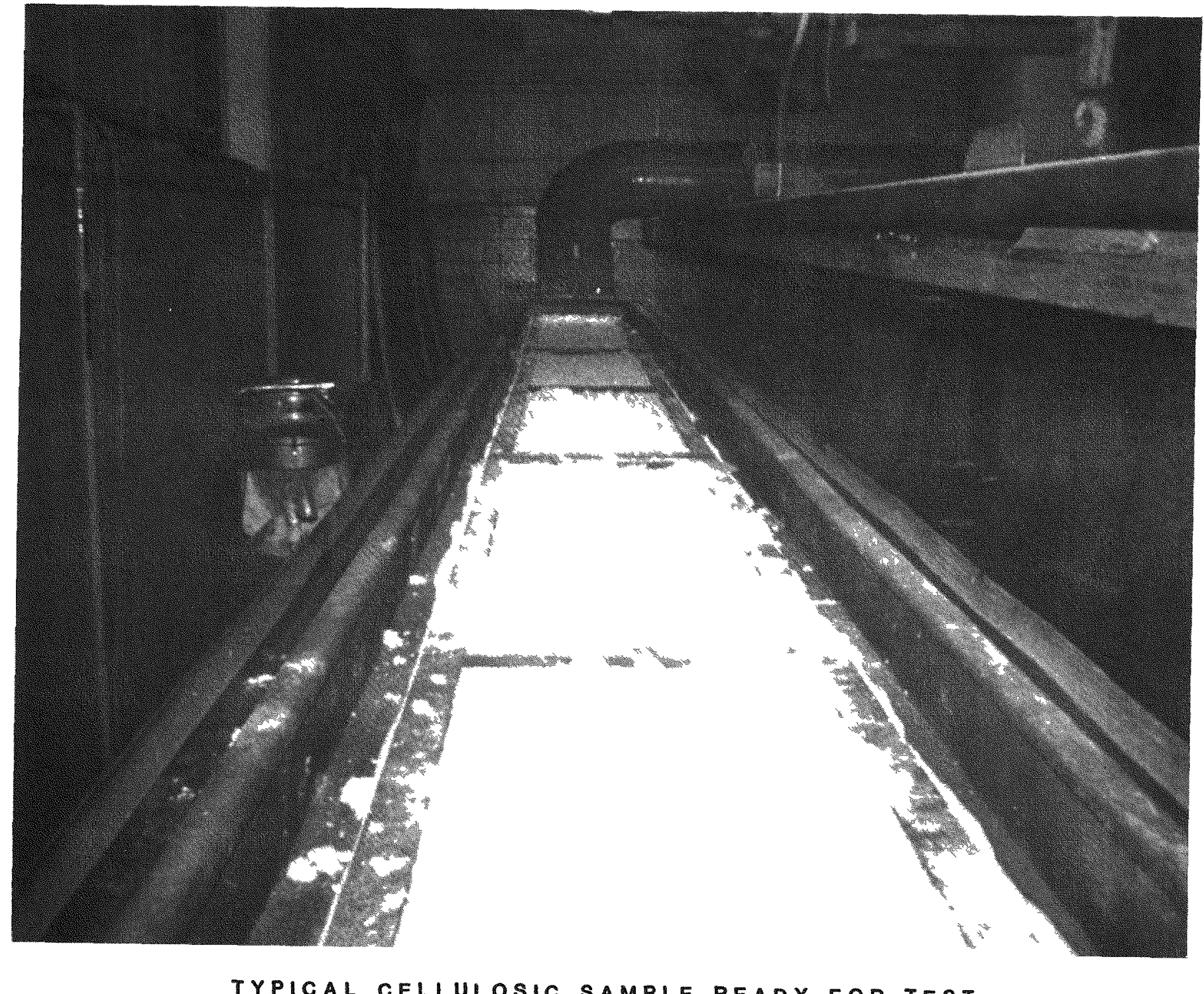

TYPICAL CELLULOSIC SAMPLE READY FOR TEST 
Page 85

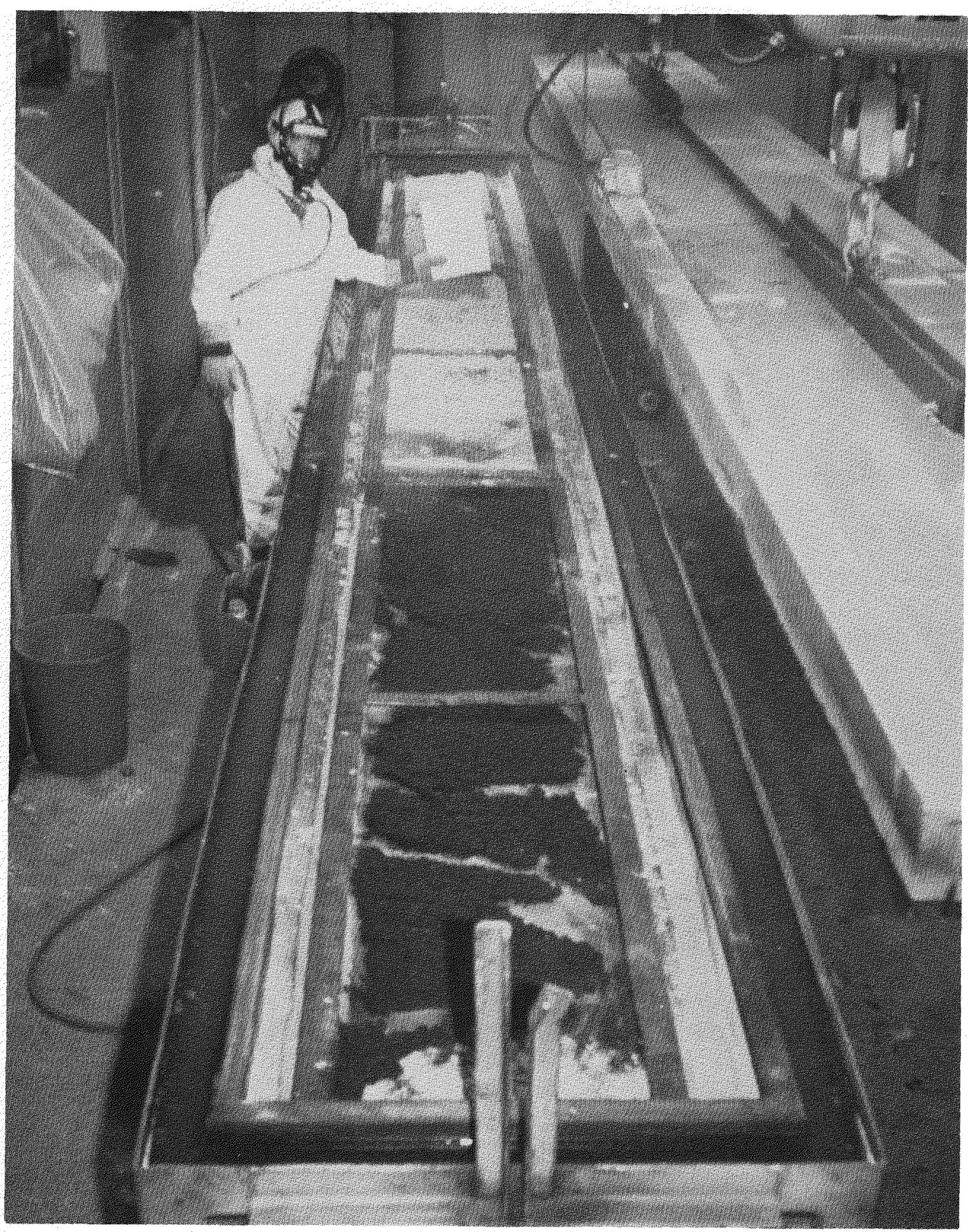

SAMPLE B POST TEST 
Page 86



SAMPLE C POST TEST 


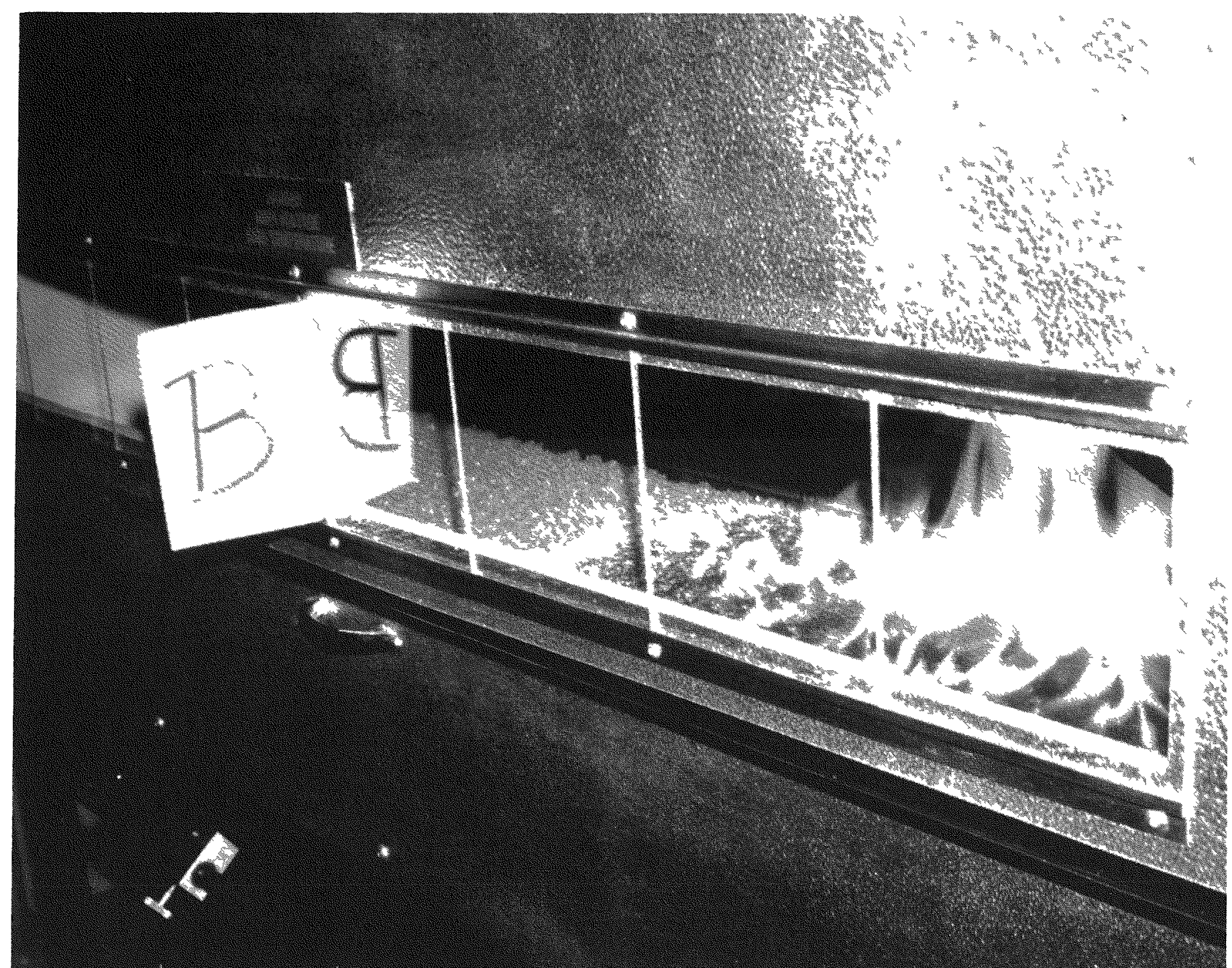

ATTIC FLOOR RADIANT PANEL TEST SAMPLE B 


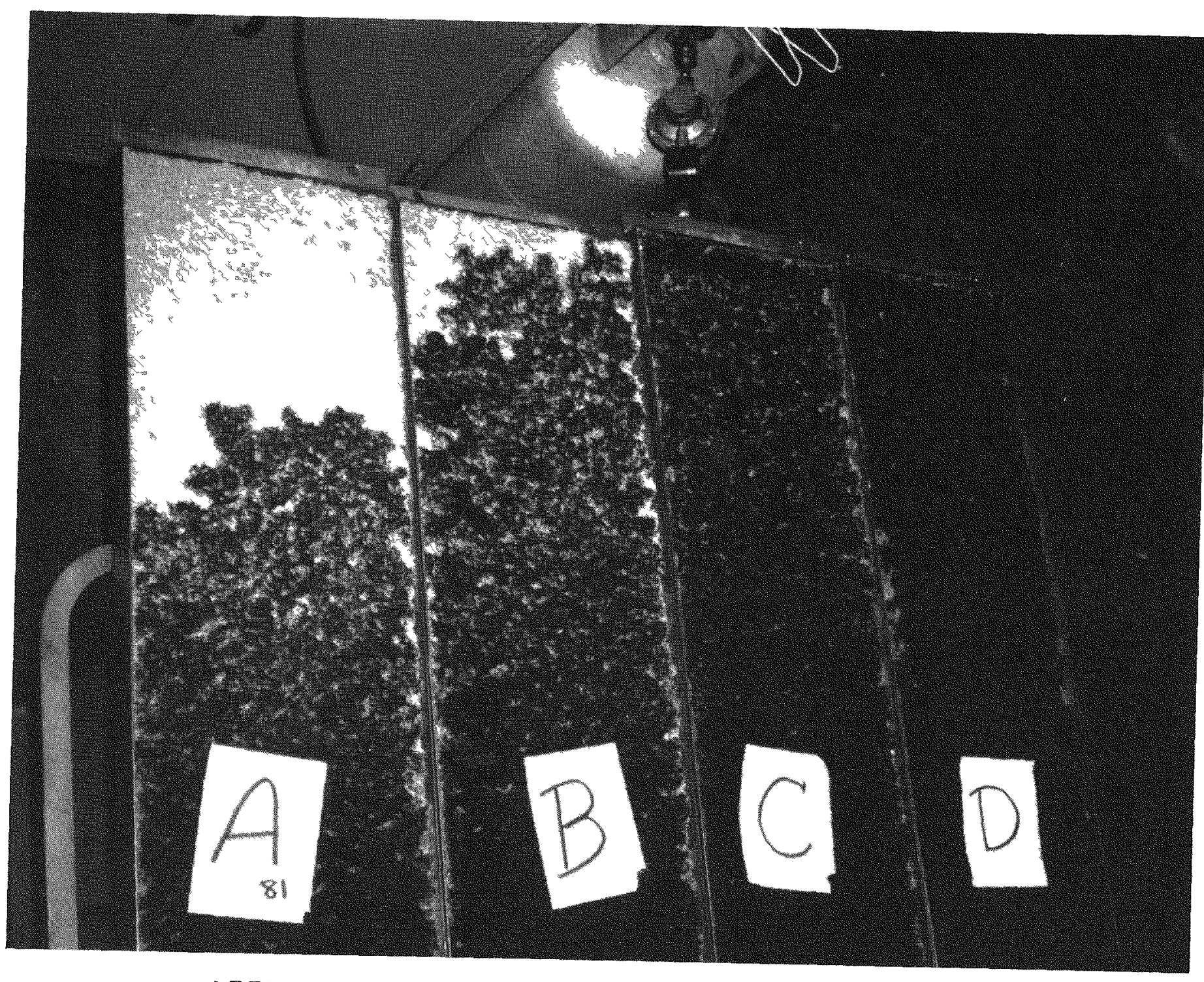

ATTIC FLOOR RADIANT PANEL SAMPLES-POST TEST 


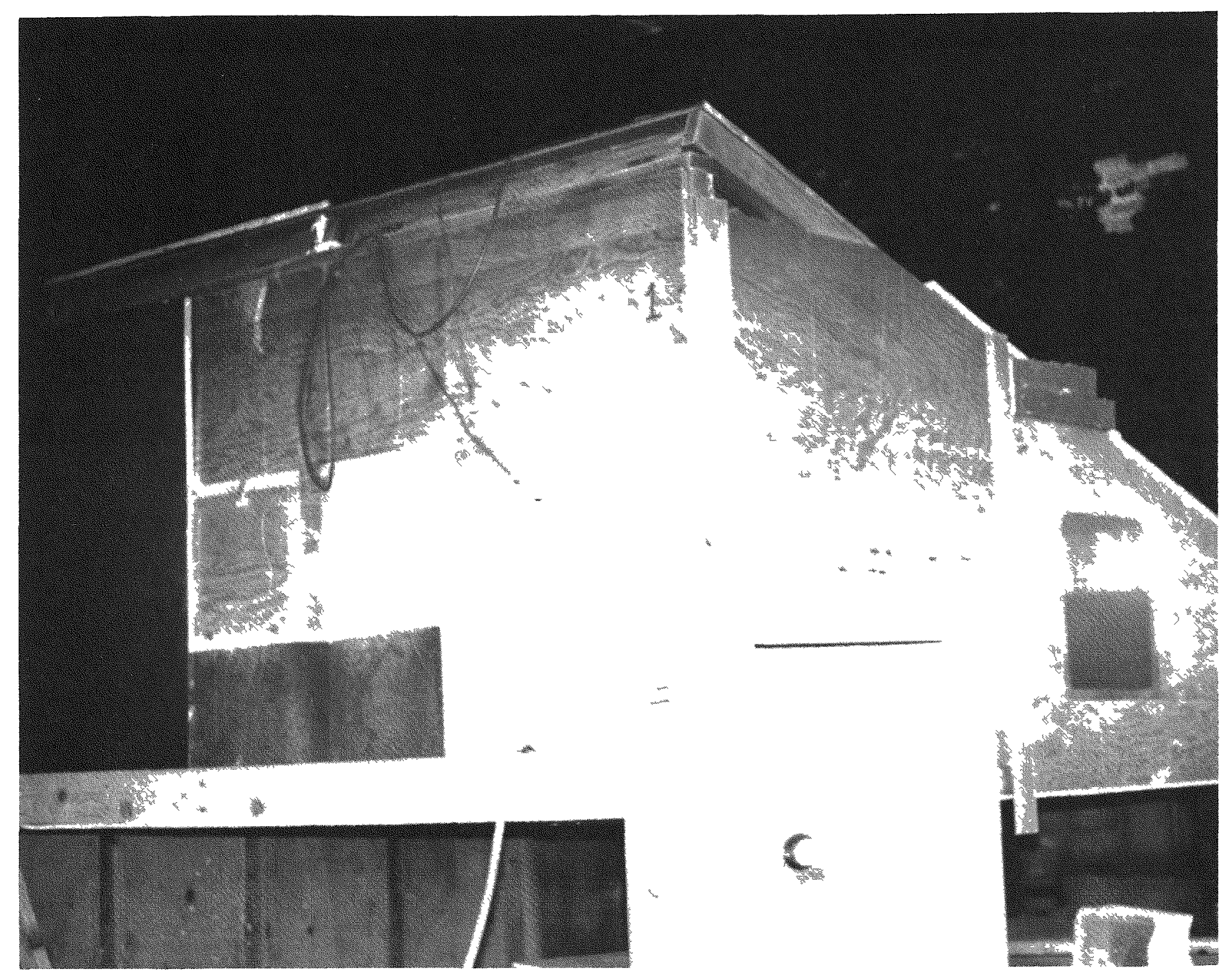


Page 90

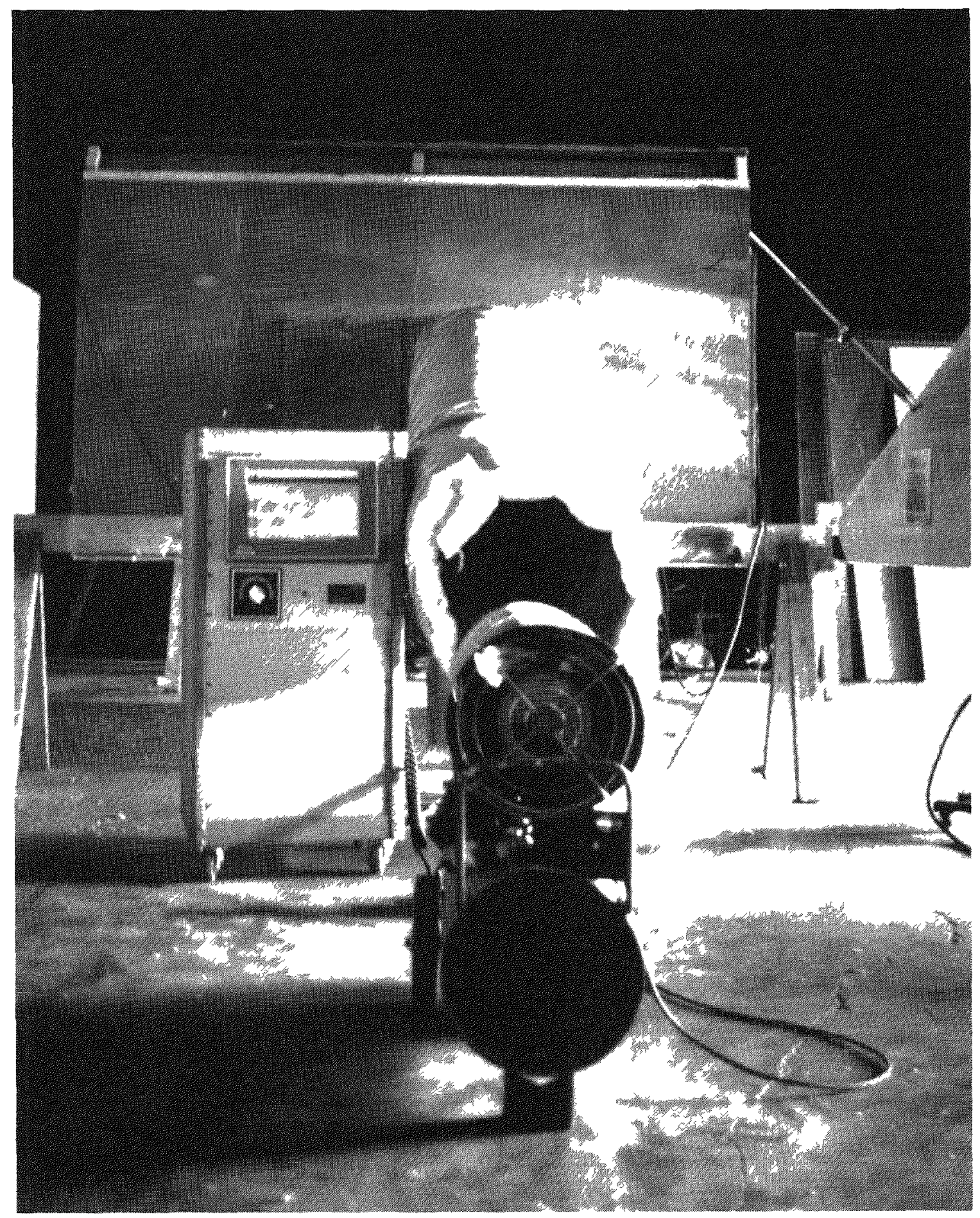

ATTIC ENCLOSURE - CONVECTIVE HEATING MODE 


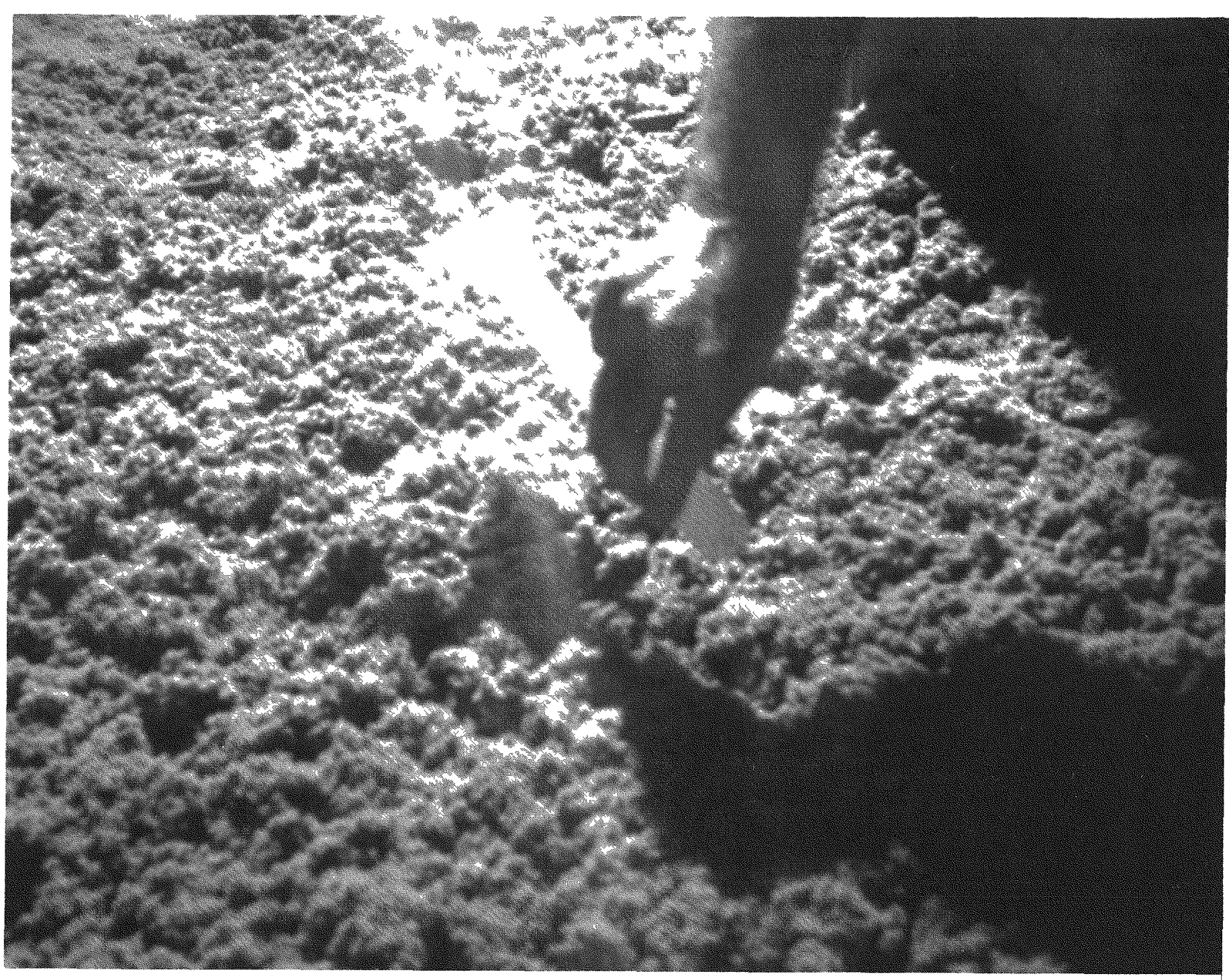


Page 92

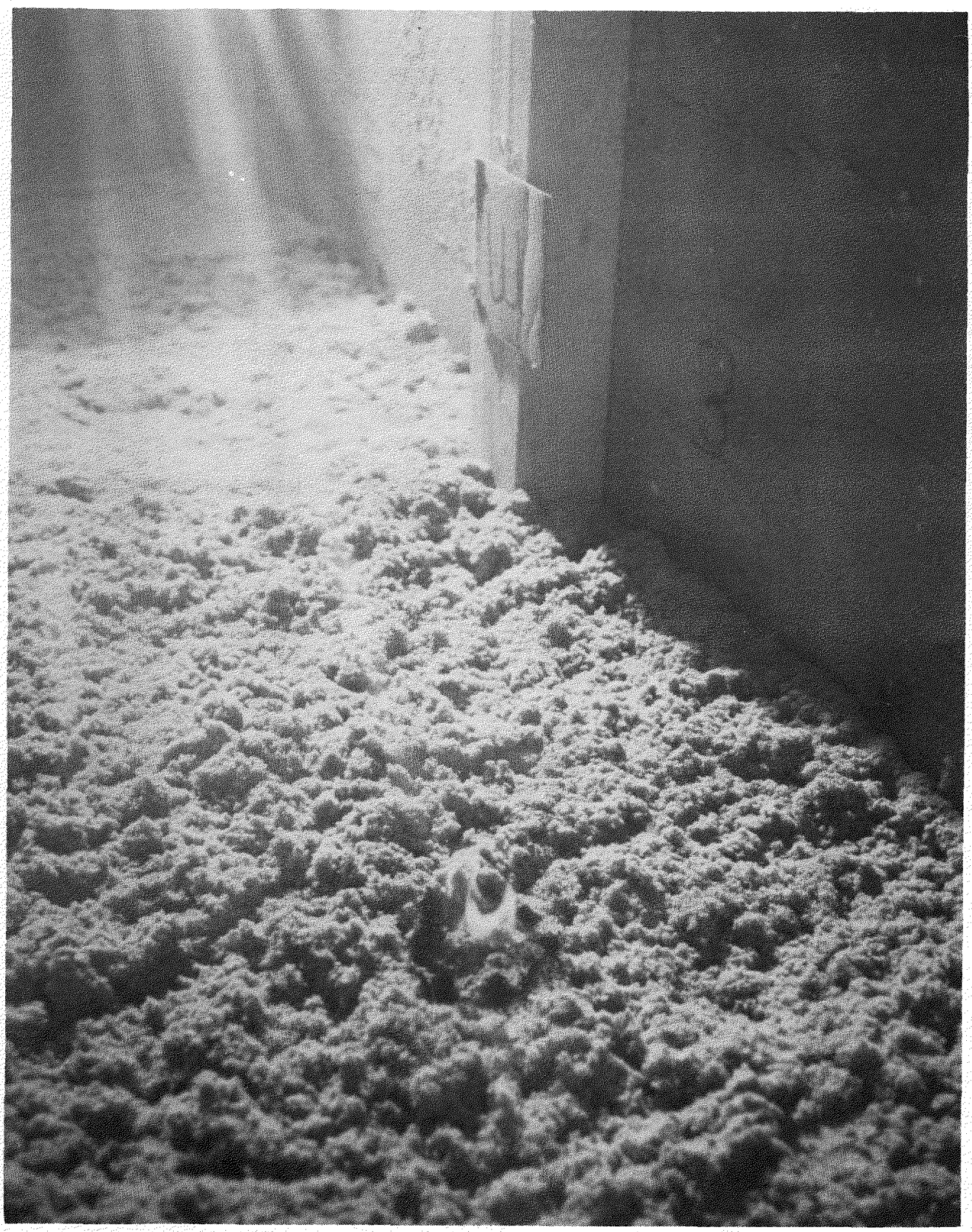

SAMPLE W-ALCOHOL SPILL 




SAMPLE B BY PROPANE TORCH 


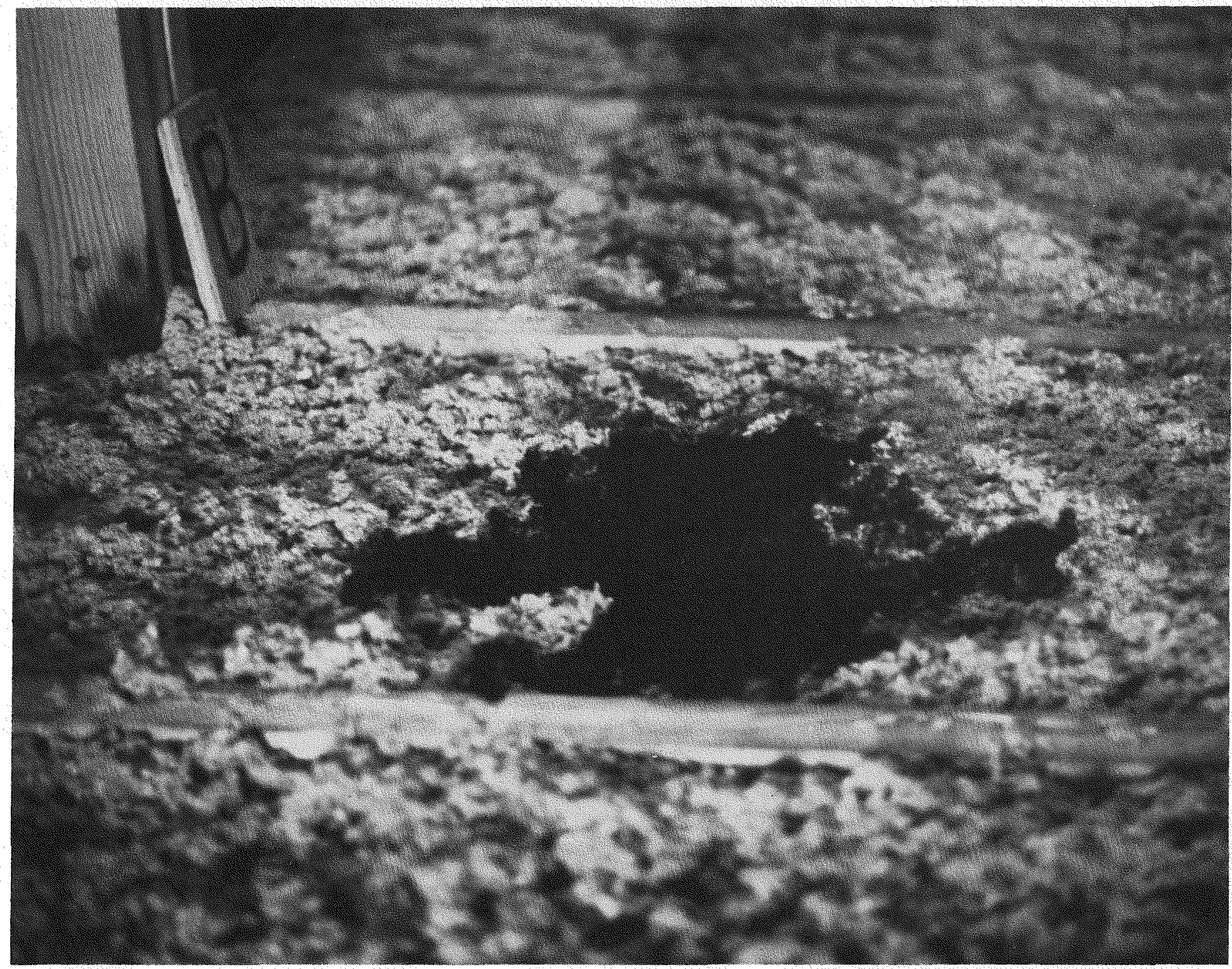

SAMPLE B BY PROPANE TORCH-POST TEST 


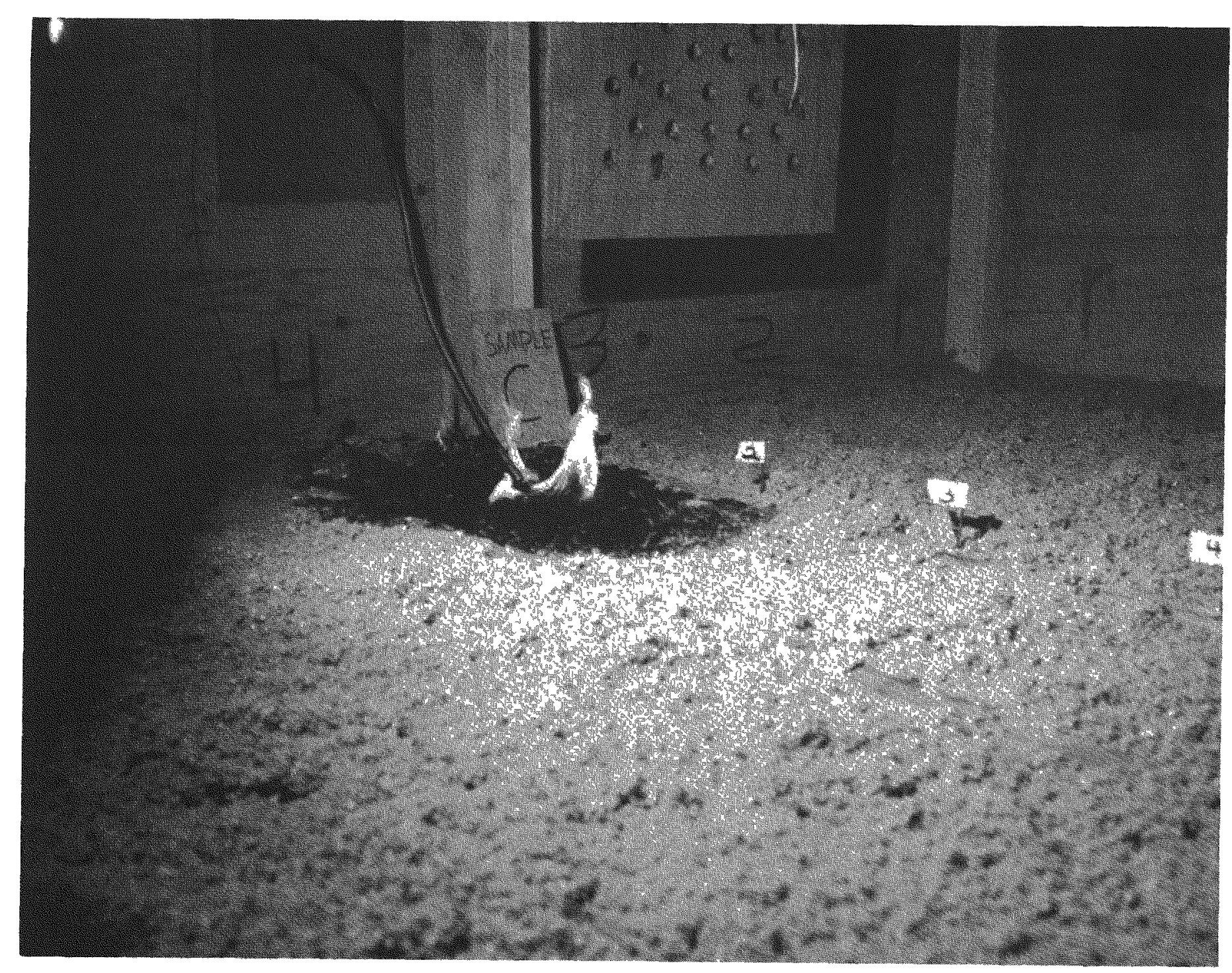




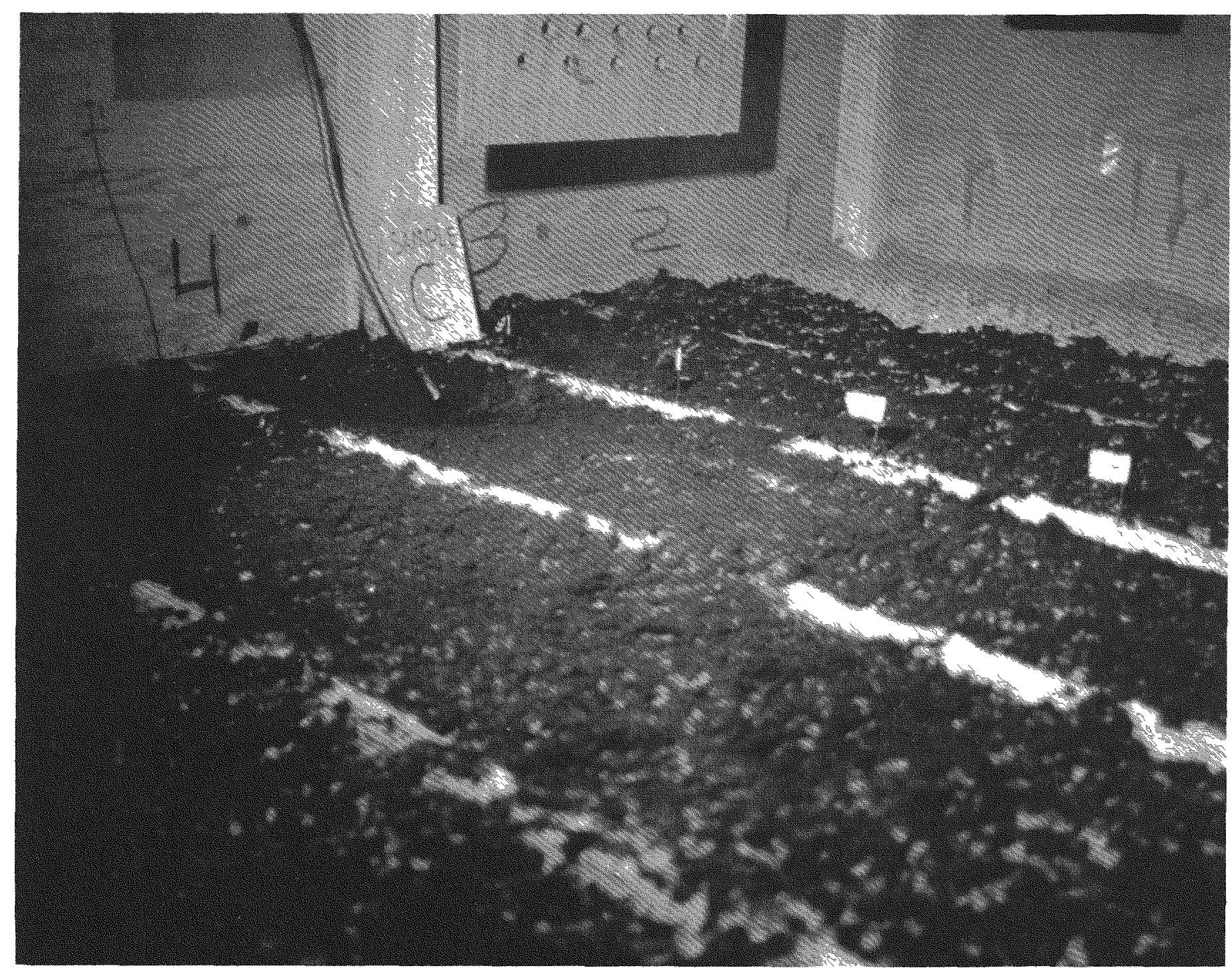

SAMPLE C BY PROPANE TORCH-POST TEST

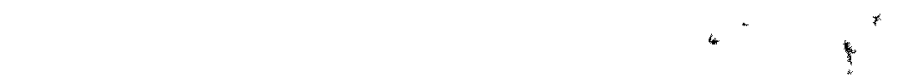




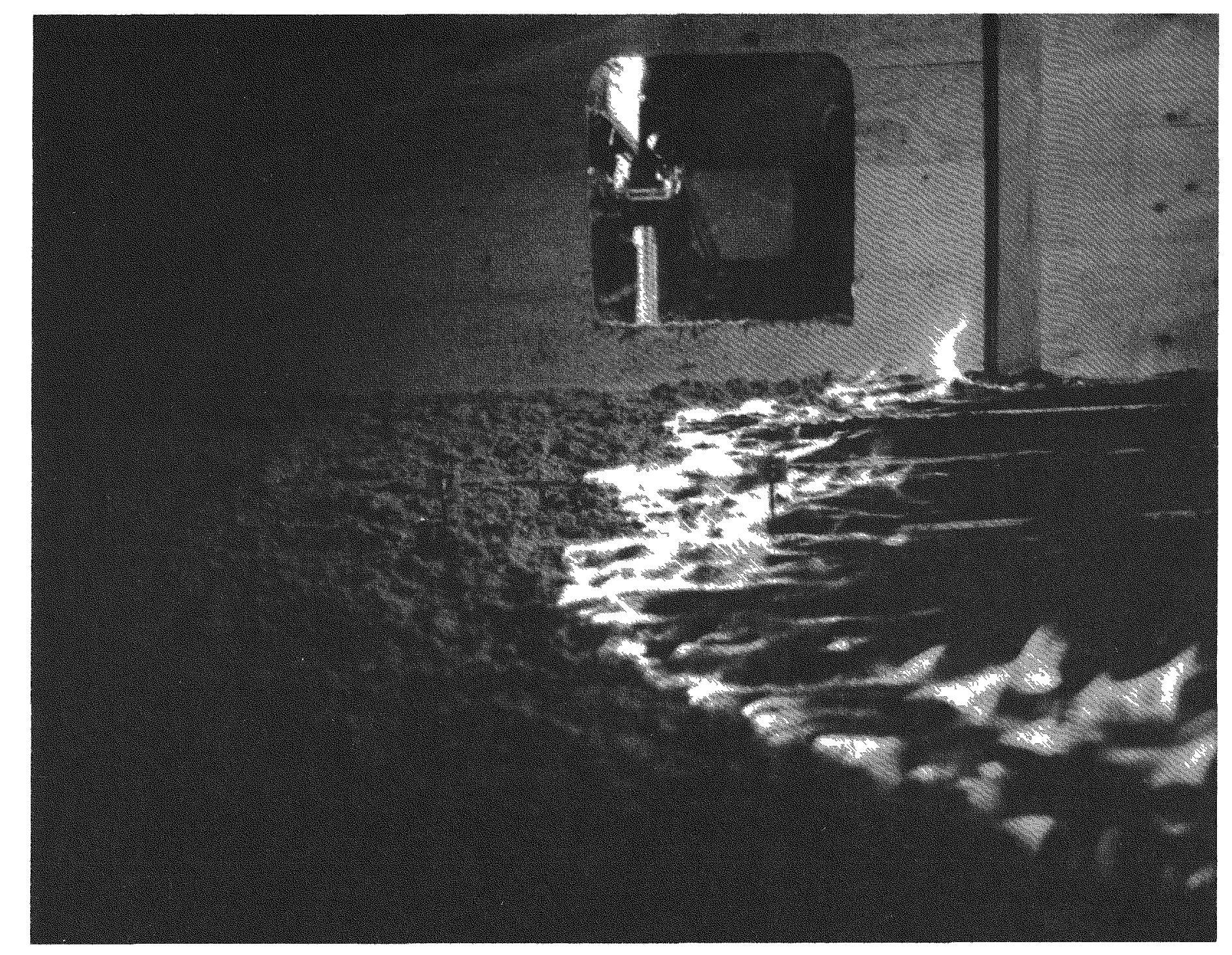

TEST NO. 3-SAMPLE C 


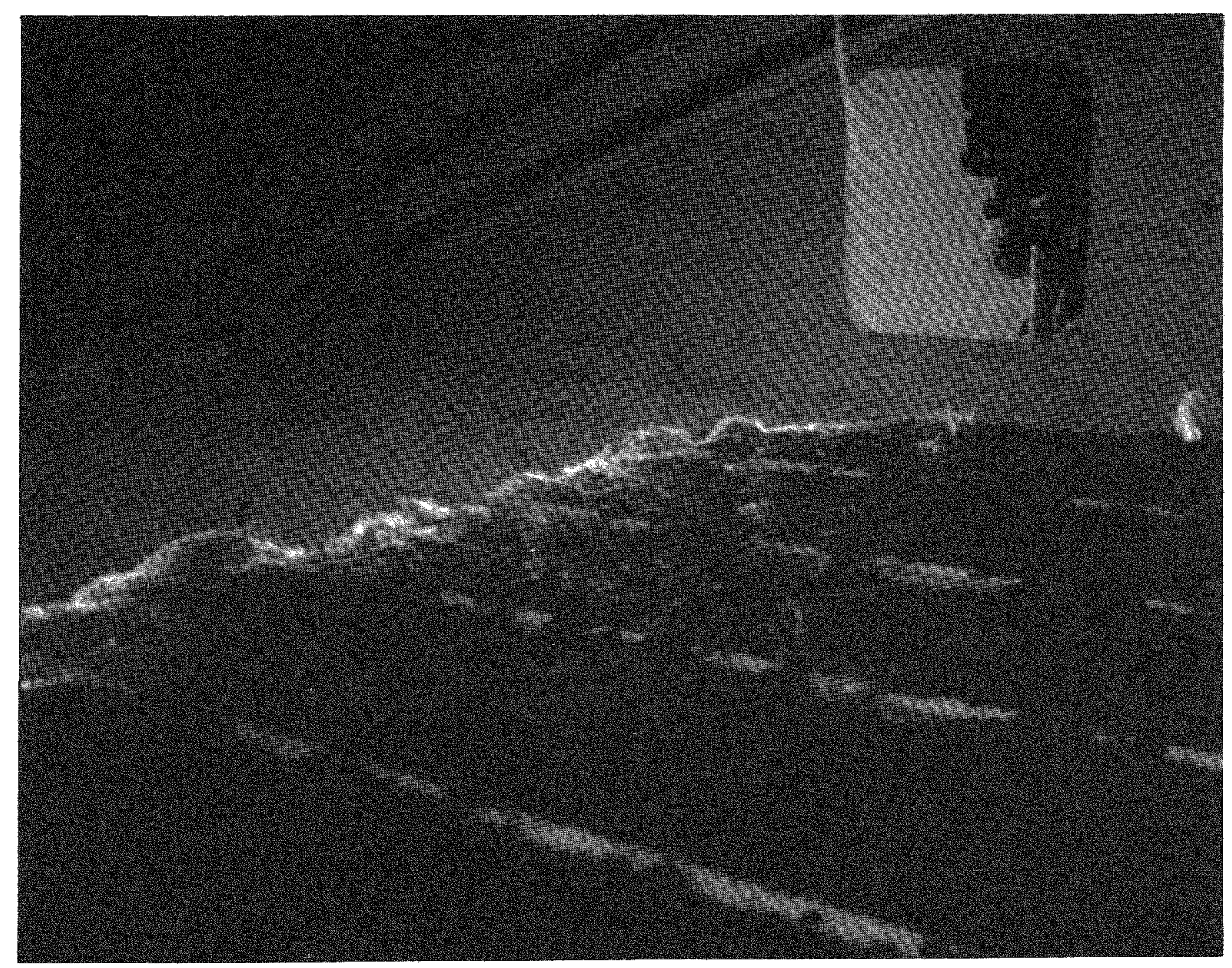

TEST NO. 36-3AMPLEK 


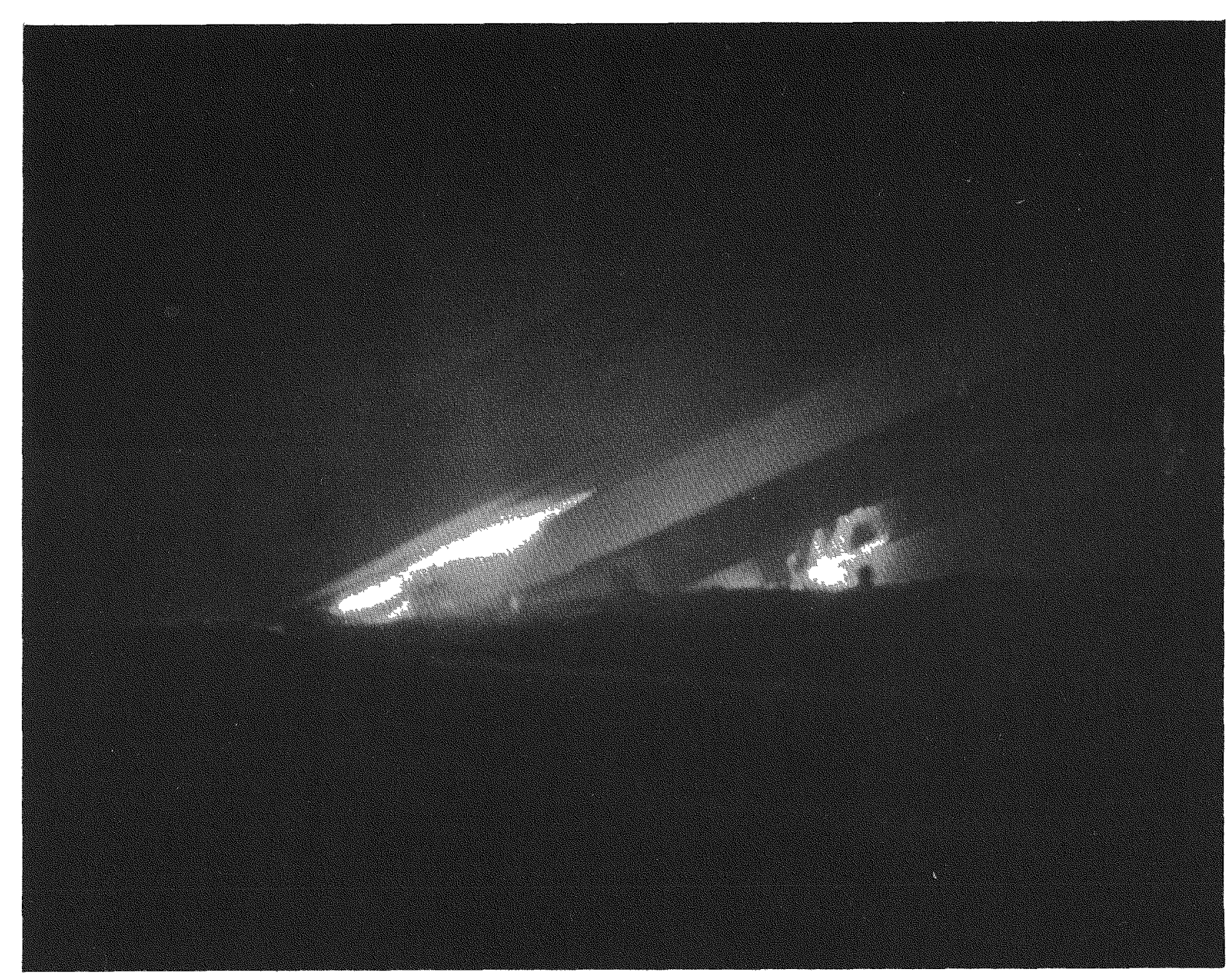

TEST NO. 37-SAMPLEM 


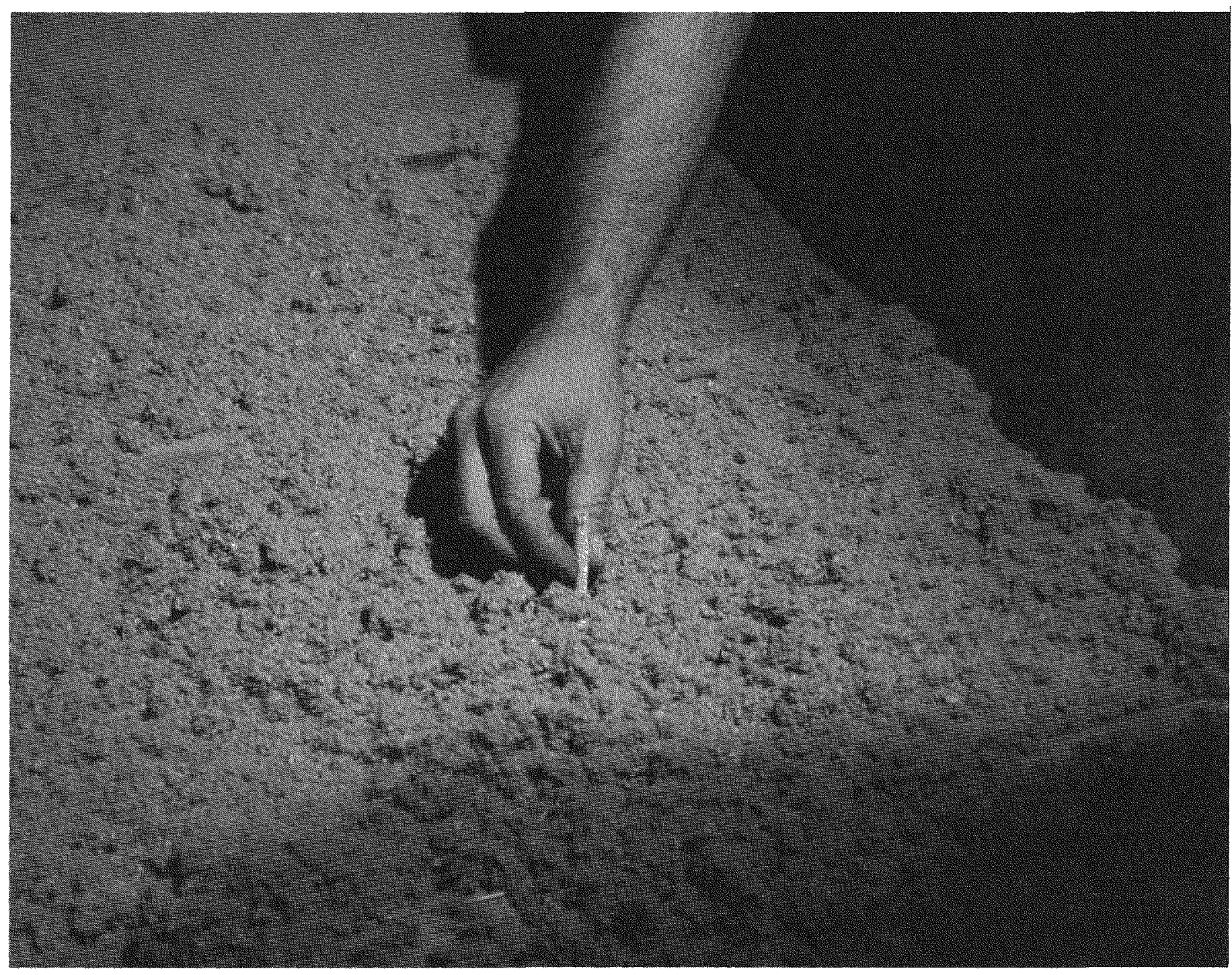

TYPICAL CELLULOSIC SAMPLE-CIGARETTE IGNITION 


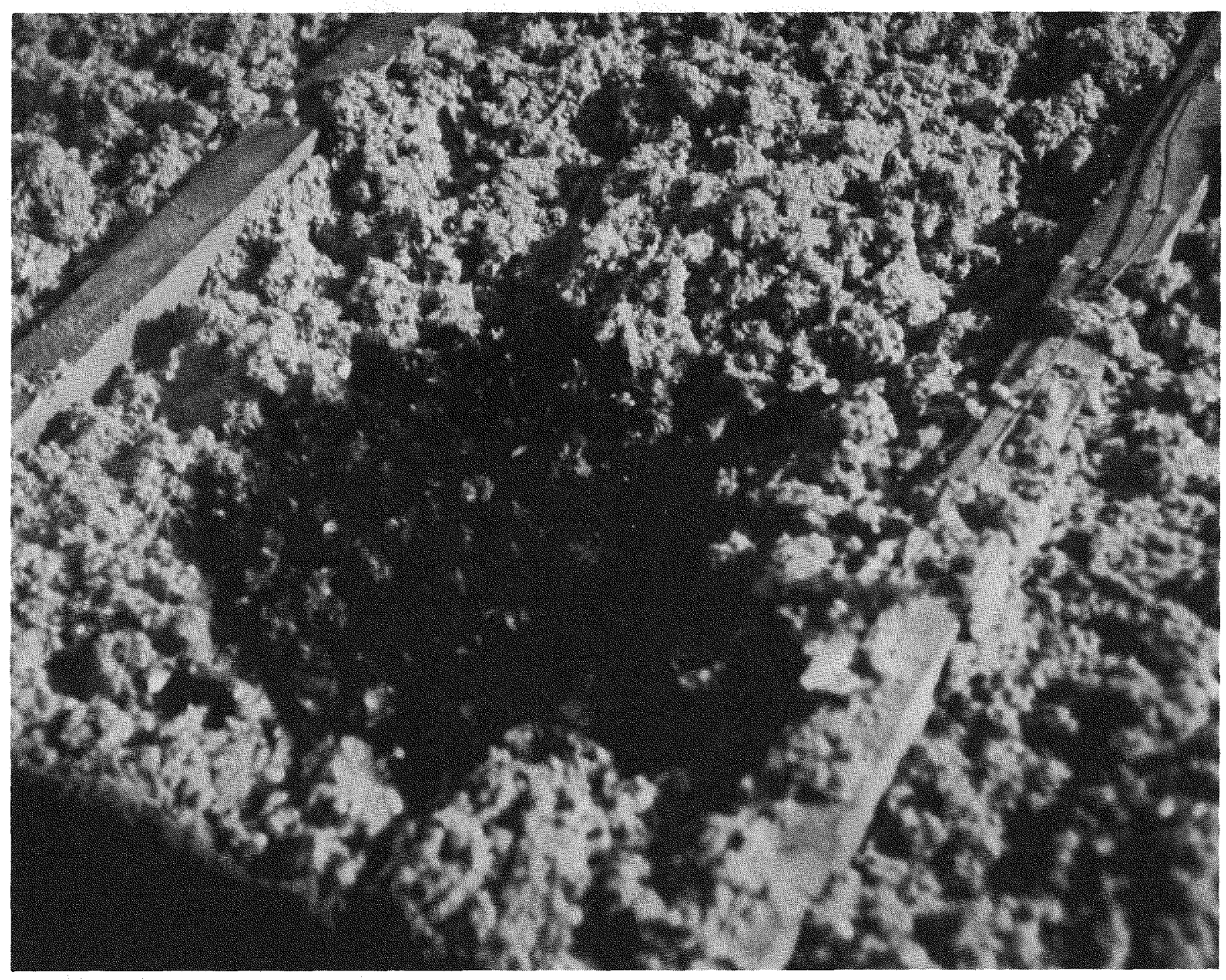

SAMPLE A-CIGARETTE IGNITION 


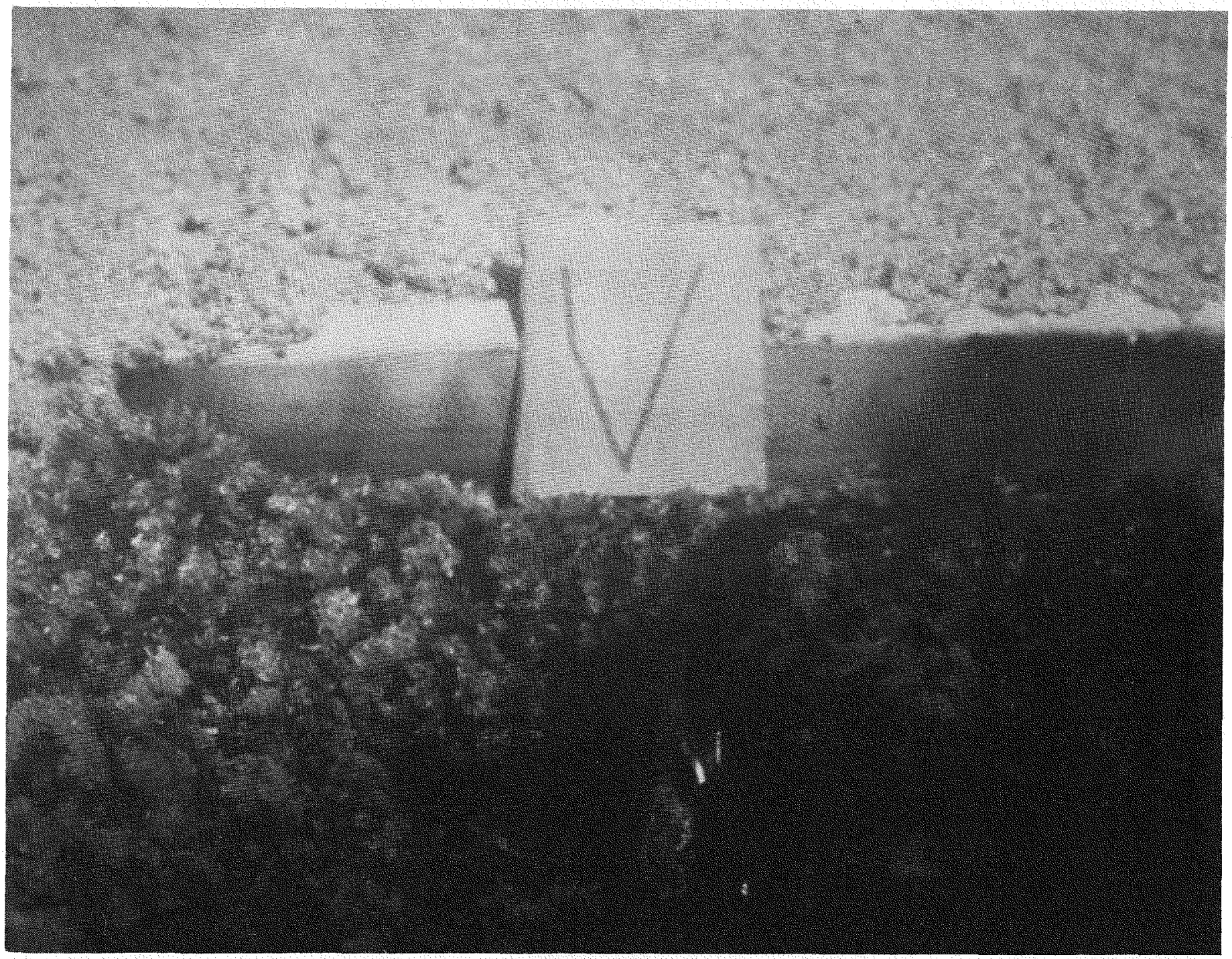

Dे
ळे
Dे

SAMPLE V-CIGARETTE IGNITION 


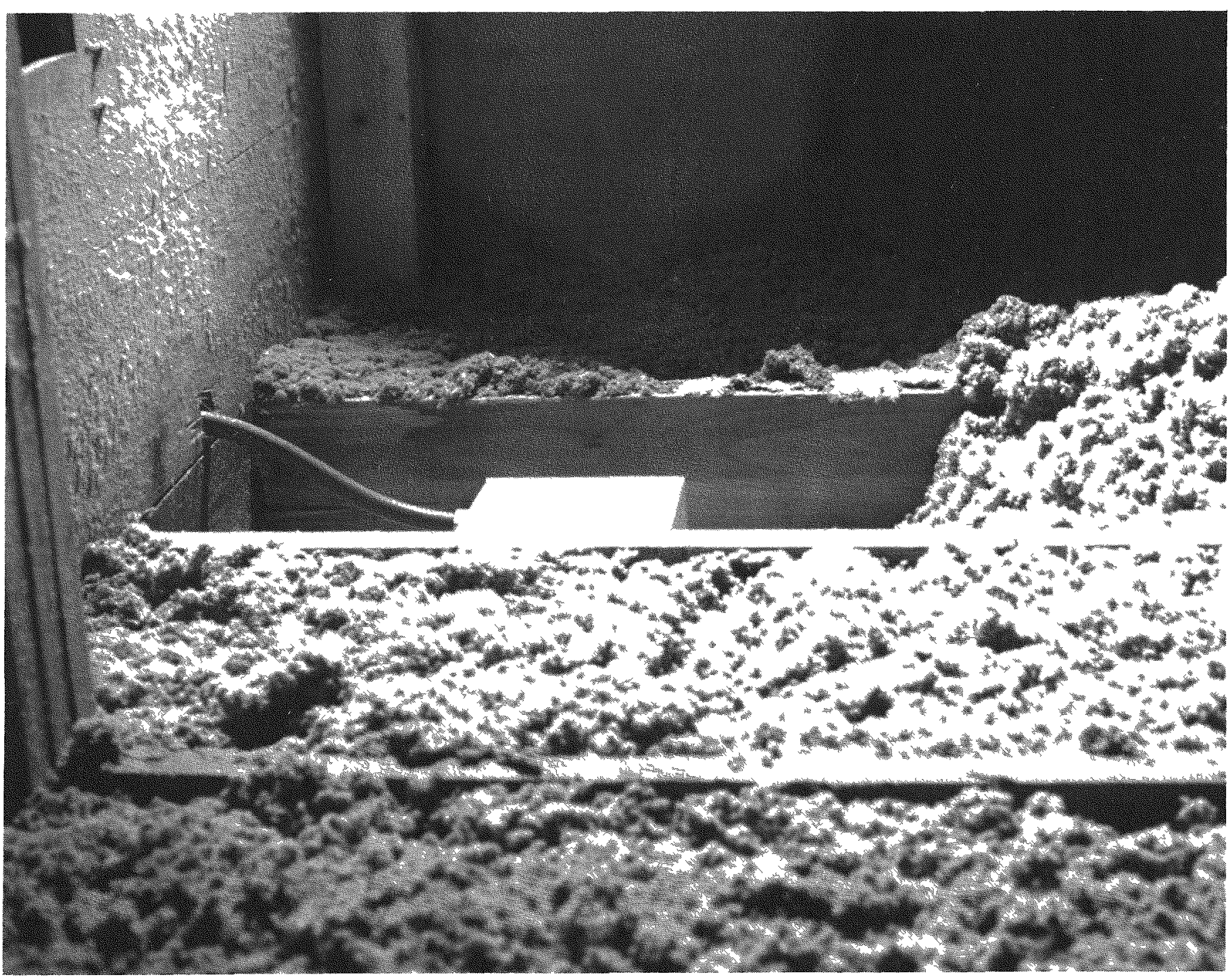




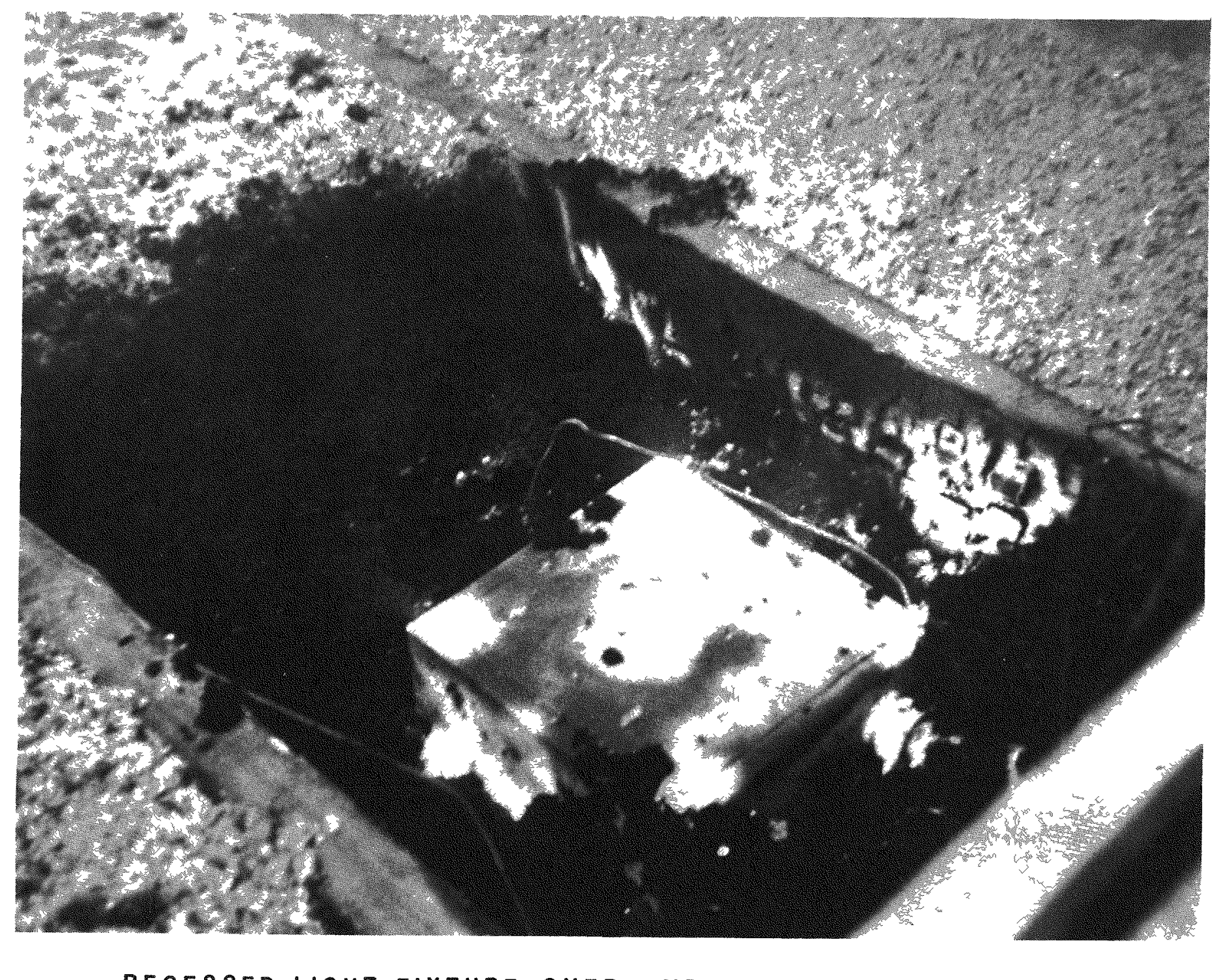

용
옹

RECESSED LIGHT FIXTURE-OVERLAMPED CONDITION-SAMPLE S 
INTERNAL DISTRIBUTION

$\mathrm{ORNL} / \mathrm{Sub} / 79-7863 / 1$

$\begin{aligned} & \text { 1. } \text { E. D. Boercker } \\ & \text { 2. } \text { R. S. Carlsmith } \\ & \text { 3. T. S. Lundy } \\ & \text { 4-13. M. C. Matthews } \\ & \text { 14. D. L. McEIroy } \\ & \text { 15. M. W. Rosentha1 } \\ & \text { 16. A. C. Schaffhauser }\end{aligned}$

\author{
17. Central Research Library \\ 18. Document Reference Section \\ 19-21. Laboratory Records \\ 22. Laboratory Records-RC \\ 23. ORNL Patent office
}

\section{EXTERNAL DISTRIBUTION}

24. R. W. Anderson, 7090 Tecumseh Lane, Chanhassen, MN

25. C. D. Auburg, DOE, Bonneville Power Admin., Portland, OR

26. E. L. Bales, Haines Lundberg Waehler, New York, NY

27. J. R. Blasius, HJH Chemicals, Inc., Phoenix, AZ

28. J. J. Boulin, DOE/CE, Washington, DC

29. B. Bromley, American Rockwool, Inc., Spring Hope, NC

30. H. W. Busching, Clemson University, Clemson, SC

31. S. H. Cady, MIMA, Summit, NJ

32. W. Carro11, Lawrence Berkeley Laboratory, Berkeley, CA

33. S. Davis, National Bureau of Standards, Gaithersburg, MD

34. W. P. Ellis, H. B. Fuller Co., Spring House, PA

35. J. Fandey, CPSC, Washington, DC

36. A. E. Fiorato, Portland Cement Assn., Skokie, IL

37. W. E. Gerken, DOE/CE, Washington, DC

38. B. F. Gilmartin, Owens-Corning Fiberglas, Washington, DC

39. L. R. G1icksman, MIT, Cambridge, MA

40. F. A. Govan, ZBA, Inc., Cincinnati, OH

41. A. Greenberg, PC, 2432 Malcolm Place, Scotch P1ains, NJ 07076

42. P. Guttmann, U.S. Borax and Chemical, Los Angeles, CA

43. J. Kempfer, Oregon DOE, Salem, OR

44-53. W. A. Kleinfelder, Underwriters Laboratories, Inc.,

54. W. M. Kroner, Rensselaer Polytechnic Institute, Troy, NY

55. F. Kubovich, Electra Manufacturing Corp., Holland, $\mathrm{OH}$

56. R. A. LaCosse, National Roofing Contractors Assn., Oak Park, LL

57. D. Lamb, TVA, Chattanooga, TN

58. E. Legex, P. 0. Box 219, New Ipswich, NH

59. R. Leuthold, FiberChem, Bucyrus, $\mathrm{OH}$

60. W. Linander, EURIMA, Roskilde, Denmark

61. R. S. Lukasz, Underwriters Laboratories, Inc., Northbrook, IL

62. H. R. Marien, Headquarters, Air Force Engineering \& Services Center, HQ AFESC/DEMM, Tyndall AFB, Florida 32403

63. J. P. Millhone, DOE/CE, Washington, DC

64. K. Mentzer, MIMA, 382 Springfield Avenue, Summit, NJ

65. W. R. Newton, TVA, Chattanooga, TN

66. T. J. Ohlemiller, National Bureau of Standards, Gaithersburg, MD 
67. R. Orlandi, W. R. Grace \& Company, Cambridge, MA

68. C. M. Pelanne, 4900 Pinyon Drive, Littleton, Co

69. L. Peterson, Technical Services Div., Thermoguard Insulation Co., Seattle, WA

70. F. J. Powe11, National Bureau of Standards, Gaithersburg, MD

71. F. Rickenbach, Urethane Foam Contractors Association, Dayton, OH

72. E. Schaffer, Forest Products Laboratory, Madison, WI

73. W. W. Seaton, ASHRAE, Atlanta, GA

74. M. Sherman, Jim Walter Research Corp., St. Petersburg, FL

75. C. J. Shirtliffe, NRC, Ottawa, Canada

76. J. A. Smith, DOE/CE, Washington, DC

77. H. S. Smith, Cellin Manufacturing Inc., Lorton, VA

78. N. Smith, 48 L. Newton STreet, St. Albans, VT 05478

79. G. A. Tsongas, Portland State University, Portland, OR

80. R. P. Tye, Dynatech R/D, Cambridge, MA

81. C. R. Vander Linden, Manville Corporation, Denver, CO

82. J. D. Verschoor, 179 Gail Lane, Bailey, CO

83. J. R. Warner, ACEC Research and Management Foundation, Washington, $\mathrm{DC}$

84. Office, Assistant Manager, Energy Research \& Development, DOE-ORO, Oak Ridge, TN

85-111. Technical Information Center, U.S. Department of Energy, POB 62, Oak Ridge, TN 
$!$

1

I 